Illinois State University

ISU ReD: Research and eData

Theses and Dissertations

$10-21-2015$

\title{
Resistance, the Church, and a Comparison of Ceramics from Sixteenth-Century Caluco, El Salvador
}

Alison Denise Hodges

Illinois State University, hodgesalison005@gmail.com

Follow this and additional works at: https://ir.library.illinoisstate.edu/etd

Part of the History of Art, Architecture, and Archaeology Commons

\section{Recommended Citation}

Hodges, Alison Denise, "Resistance, the Church, and a Comparison of Ceramics from Sixteenth-Century Caluco, El Salvador" (2015). Theses and Dissertations. 483.

https://ir.library.illinoisstate.edu/etd/483

This Thesis is brought to you for free and open access by ISU ReD: Research and eData. It has been accepted for inclusion in Theses and Dissertations by an authorized administrator of ISU ReD: Research and eData. For more information, please contact ISUReD@ilstu.edu. 


\title{
RESISTANCE, THE CHURCH, AND A COMPARISON OF CERAMICS FROM SIXTEENTH-CENTURY CALUCO, EL SALVADOR
}

\begin{abstract}
Alison D. Hodges
154 Pages

This thesis examines ceramics from the church of San Pedro y San Pablo, Caluco, El Salvador, to investigate the pressures of Spanish evangelization during the Colonial Period. It compares the church's ceramic assemblage to two privately-owned houses, also within Caluco. Examining choices in ceramic styles for serving food and drink is one way to examine the colonial policies of reducción, which were to instill a regular, commonplace Christian order in everyday life. The materials in question were a large number of Spanish majolicas, as well as 300 locally-made vessels, and form, decoration, and ware was noted for each. The relative importance of majolica versus majolica attributes on indigenous-made pottery shows that practices in the shadow of the church were distinct from those farther away. Residents of Caluco faced harsh conditions because of greed and abuse related to cacao production. Subverting canonical material practices was a way to band together.
\end{abstract}

KEYWORDS: Ceramics, Colonialism, El Salvador, Evangelization, Resistance, Sixteenth Century 
RESISTANCE, THE CHURCH, AND A COMPARISON OF CERAMICS FROM SIXTEENTH-CENTURY CALUCO, EL SALVADOR

\author{
ALISON D. HODGES
}

A Thesis Submitted in Partial Fulfillment of the Requirements for the Degree of

MASTER OF SCIENCE

Department of Sociology and Anthropology

ILLINOIS STATE UNIVERSITY 
Copyright 2015 Alison D. Hodges 
RESISTANCE, THE CHURCH, AND A COMPARISON OF CERAMICS FROM SIXTEENTH-CENTURY CALUCO, EL SALVADOR

ALISON D. HODGES

COMMITTEE MEMBERS:

Kathryn Sampeck, Chair

Elizabeth Scott 


\section{ACKNOWLEDGMENTS}

I am not a wordy person, so I will keep this short. However, brevity does not signify level of gratefulness. I would like to thank Drs. Sampeck and Scott, Cori Rich, Deb Neidich, Melissa Frederick, Ian Fricker, Erin Whitson, several friends from home (Lindsay Pearce, Kim Vasut-Shelby, Jessica Dalton-Carriger, and Bobby Braly), and my parents and grandparents. You all know what you did.

This thesis is dedicated to Wally. I'm sorry you didn't get to read it.

A.D.H. 


\section{CONTENTS}

Page

ACKNOWLEDGMENTS

CONTENTS

FIGURES $\quad$ v

CHAPTER

I. HISTORICAL BACKGROUND 1

The Setting: Geography and People of El Salvador 2

Preconquest Religion $\quad 5$

Archaeological Patterning of Religion 6

European Expansion $\quad 7$

$\begin{array}{ll}\text { Spain before the Conquest } & 7\end{array}$

Spanish Conquest of the Americas 9

Central America 9

Impacts of Spanish Invasion $\quad 10$

$\begin{array}{ll}\text { Arrival of the Clergy } & 12\end{array}$

Caluco, El Salvador $\quad 15$

Archaeology in Caluco 16

$\begin{array}{ll}\text { Summary } & 17\end{array}$

II. REVIEW OF THE SCHOLARLY LITERATURE AND THEORETICAL FRAMEWORK

Historical Research 19

Archaeology of Colonial Ecclesiastical Settings 20

$\begin{array}{ll}\text { Archaeology of Colonialism } & 21\end{array}$

Archaeology of Resistance $\quad 22$

Archaeology of the 16th to 17th Century in Spanish America 25

Spanish Artifacts in the Colonies 26

$\begin{array}{ll}\text { Theoretical Framework } & 27\end{array}$

$\begin{array}{ll}\text { Cultural Change } & 27\end{array}$

Creolization 28 
Transculturation $\quad 29$

Resistant Accommodation 29

My Theoretical Framework $\quad 30$

Marxian Theory $\quad 30$

Practice Theory $\quad 32$

Summary 33

III. METHODS OF ANALYSIS $\quad 34$

Material Culture of Ecclesiastical Settings 35

Household Ceramics 35

Earthenwares $\quad 36$

Catalina Red-on-White $\quad 36$

Pantaleón 36

Teofilo 37

Raimundo $\quad 37$

Dario $\quad 37$

Apolonio Orange Red $\quad 37$

Telesforo Plain 38

Teshcal Red-on-Natural 38

Camilo 38

Olive Jar $\quad 38$

Majolicas $\quad 39$

Vessel Forms $\quad 41$

Decorations $\quad 42$

Summary $\quad 43$

IV. ANALYSIS OF MATERIALS 44

Forms $\quad 44$

Types $\quad 48$

Decorations $\quad 52$

Pie Crust Rims $\quad 53$

$\begin{array}{lll}\text { V. DISCUSSION } & 57\end{array}$

$\begin{array}{lr}\text { Forms Present in Caluco } & 58\end{array}$

Forms Present at San Pedro y San Pablo 59

Forms Present at House Q $\quad 60$

Forms Present at House R 61

Ware Types Present in Caluco $\quad 61$ 
Earthenware Types in Caluco $\quad 61$

Majolicas in Caluco $\quad 62$

Majolicas at San Pedro y San Pablo 63

Majolicas at House Q 64

Majolicas at House R 64

Decorations $\quad 65$

Colonoware Comparison $\quad 66$

Colonoware Forms Comparison $\quad 69$

Colonware Decoration Comparison $\quad 71$

$\begin{array}{ll}\text { Majolica } & 72\end{array}$

Pie Crust Rims $\quad 72$

Two Houses $\quad 72$

$\begin{array}{ll}\text { Candeleros } & 74\end{array}$

$\begin{array}{ll}\text { Summary } & 74\end{array}$

VI. CONCLUSION

$\begin{array}{ll}\text { REFERENCES } & 79\end{array}$

APPENDIX A: Complete Ceramic Inventory 92

APPENDIX B: Majolica Types Compared by Location 139

APPENDIX C: Number of Vessels of Each Type Compared by Location 141

APPENDIX D: Majolica Decorations Compared by Type 145

APPENDIX E: Vessel Types Compared by Location 147

APPENDIX F: Vessel Forms Compared by Majolica Types and Location 149

APPENDIX G: Vessel Forms Compared by Type and Location 151

APPENDIX H: Pie Crust Rims 


\section{FIGURES}

Figure $\quad$ Page

1. Location of El Salvador 3

2. Total Identified Forms for all Types and Sites 45

3. Forms Present at San Pedro y San Pablo 46

4. Forms Present at House Q 47

5. Forms Present at House R 47

6. Total Identified Earthenware Types for all Sites 48

7. Earthenware Types Compared by Sites 49

8. Total Glazed Ware Types for all Sites $\quad 50$

9. Glazed Ware Types Present at San Pedro y San Pablo 51

10. Glazed Ware Types Present at House Q 51

11. Glazed Ware Types Present at House R 52

12. Total Decorations For all Types and Sites 52

13. Decorations Compared by the Three Locations 53

14. Percentages of Vessels with Pie Crust Rims to Total Vessels from all Three Locations

15. Percentages of Vessels without Pie Crust Rims to Total Vessels from all Three Locations 


\section{CHAPTER I}

\section{HISTORICAL BACKGROUND}

Missionaries arrived specifically to convert Indians to Christianity. While clergy committed many abuses and dedicated themselves to marginalizing Mesoamerican ideas and practices, some also helped control abuse of the Indians by the Spanish (Hanks 2010; MacLeod 2008). Franciscan missionaries viewed the conquest as the force that would convert all people to Christianity and would lead to the second coming of Jesus (Restall 2003). This was accomplished in an "orderly" manner, and churches were constructed using materials taken from the temples the missionaries destroyed (Hanks 2010: 3). The Church viewed Indian religion as pagan (Graham 1991; Overmyer-Velázquez 2005), and Indians fought back against the missionaries and their Christian message, an example of which was the erection of a stela in the nave of the church in Lamanai, Belize (Pendergast 1991). Other artifacts have been discovered to have been used in resistance;

ceramics are just as likely to have been used in this way, as well (Deagan 2010; Charlton and Fournier 2010; Hill 1991, 1992; Orser 1996; Rodríguez-Alegría 2008; Silliman 2001). Ceramics, after all, are "an archaeologically sensitive indicator of external contact and change" (Skowronek 1998: 56).

With my thesis, I hope to contribute to the research by examining the issue of resistance in a church setting during the colonial period by analyzing how ceramic characteristics of form, decoration, and ware vary from contexts in and around the 
sixteenth-century parish church of San Pedro y San Pablo in Caluco, western El Salvador versus two privately-owned indigenous domestic sites in Caluco at a distance from the church.

The questions I was hoping to answer were: 1) did the Pipil of Caluco, El Salvador, resist evangelization at San Pedro y San Pablo? 2) Can resistance be determined by comparing ceramics of the church to ceramics from privately-owned residences? 3) What are the characteristics of the ceramics in the area of the church in Caluco? 4) How do ceramic ware, form, and decoration indicate conformity or resistance? 5) How do church area ceramics compare to private, domestic contexts in Caluco? Analysis was conducted by comparing the ceramics from the church, San Pedro y San Pablo, to two privately-owned houses, $\mathrm{Q}$ and $\mathrm{R}$, also from Caluco. The two houses were chosen because of the amount of ceramics recovered from them. For all three locations, the materials were analyzed by looking at ceramic type, vessel form, and decoration techniques. Ceramic types were broken down by each individual type, but will be discussed in the analysis chapter broadly (coarse earthenware, majolica, refined ware).

\section{THE SETTING: GEOGRAPHY AND PEOPLE OF EL SALVADOR}

El Salvador (Figure 1) is located on the Pacific Ocean side of Central America, between Guatemala and Honduras (Beverley 1982). Historically, all of El Salvador was located in colonial Guatemala (MacLeod 2008). 
Figure 1. Location of El Salvador. Licensed under CC BY-SA 3.0 via Wikimedia Commons.

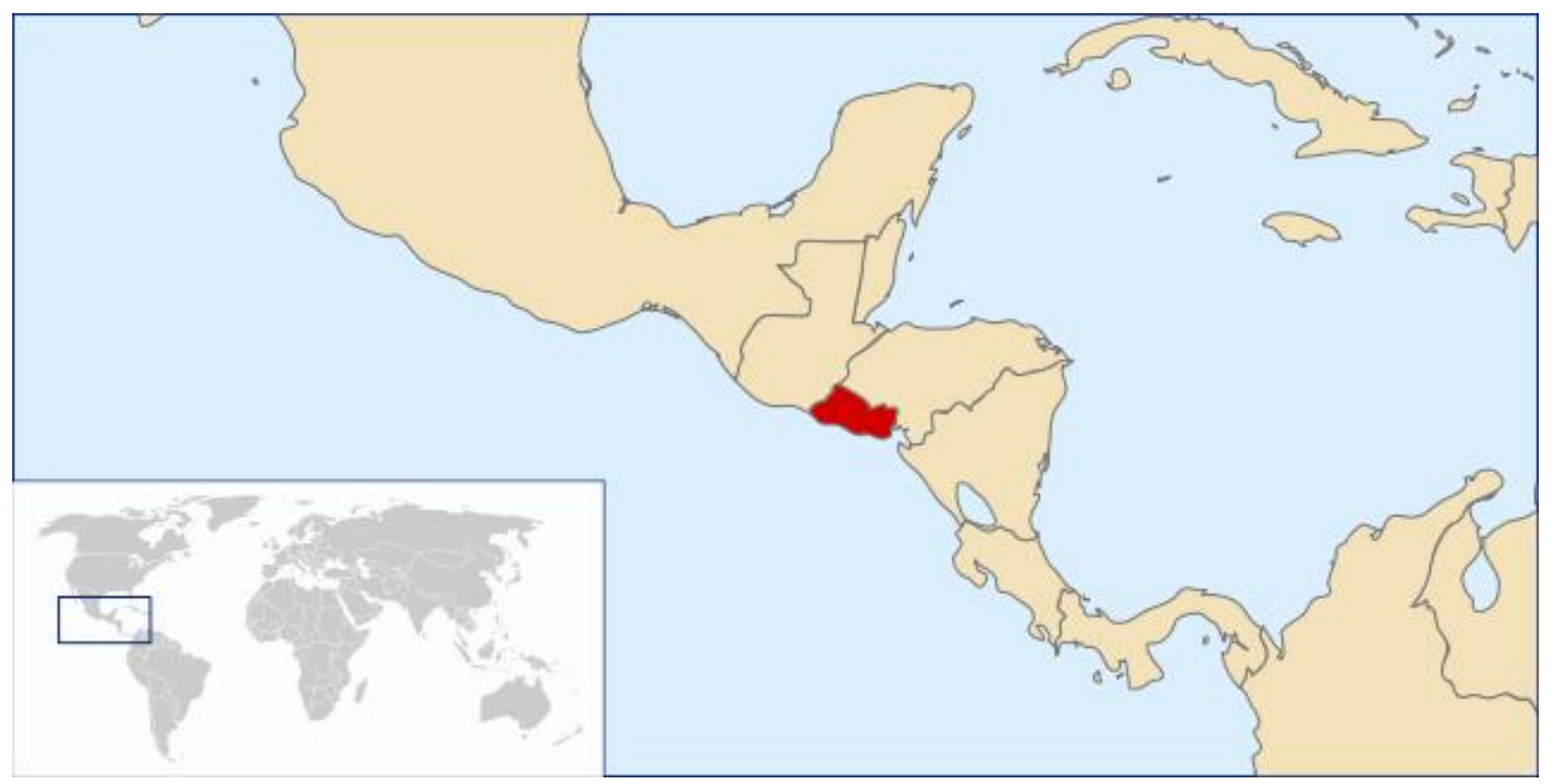

The ethnic group in El Salvador immediately before the arrival of the Spanish was the Pipil (Fowler 1995; Verhagen 1997), whose language was related to the Nahuatl of Mexico who migrated from there between 700 to $1350 \mathrm{AD}$ (Fowler 1985; Verhagen 1997). Pre-Columbian Pipil society was organized into wards, calpolli, and altepetl, in which the altepetl was the larger unit, and each usually contained between four and eight calpolli (Fowler, 2006; Lockhart 1992; MacLeod, 2008; Verhagen 1997). The calpolli were comprised of wards, which contained from 20 to 100 households (Fowler 2006; Lockhart 1992). Each ward had a leader who managed land allocation, tax and tribute collection, and other responsibilities (Fowler 2006; Lockhart 1992). Each calpolli had its own central urban centers, but the calpolli were not thought of as separate cities; they were all a part of the altepetl system (Fowler 2006; Lockhart 1992). 
The five calpolli in Caluco each had its own name, leader, god, market, and land, were equal to each other, and these calpolli formed an altepetl (Fowler 2006; Sampeck 2007; Verhagen 1997). The altepetl are what organized political, economic, and social life for the Pipil (Fowler 2006; Lockhart 1992; Sampeck 2007), and are also composed of a territory and a dynastic ruler, or tlatoani (Fowler 2006; Lockhart 1992; Sampeck 2007).

There were commoners, nobility, and slaves within Pipil society, with some of the commoners responsible for agriculture (mainly cacao production) and subsistence, while others were artisans, traders, vendors, and soldiers (Fowler 2006; Verhagen 1997). The nobles directed agricultural pursuits, declared war, and performed other ceremonial and political duties (Fowler 2006; Verhagen 1992). The slave population resulted from warfare, but parents could also sell their children into slavery to get out of debt (Fowler 2006; Verhagen 1997).

Other aspects of culture in pre-Columbian Pipil society, and Mesoamerica as a whole, include cacao, maize, bean, and squash agriculture (MacLeod 2008). Corn, beans, and squash were grown in many areas, but not worshipped to the extent that they were in Mesoamerica (MacLeod 2008:28). Unique features to the region include warfare (with the use of obsidian weapons and the purpose of gathering victims to sacrifice), architecture (pyramids and ball courts), a calendar (an eighteen-month year), a market system (specialized caste of merchants), and human sacrifice (Fowler 1991, 2006; MacLeod 2008). 


\section{PRECONQUEST RELIGION}

Preconquest religion in El Salvador shared some characteristics with other parts of Mesoamerica (Gasco 2005). People were supposed to do certain acts and abstain from others to encourage the gods to intervene on their behalf; certain actions needed to be done to prevent the gods from destroying the world or universe, as they had done in the past (Gasco 2005). These actions affected all aspects of life: ritual, political, social, and economic (Gasco 2005). Order was important, and any kind of excess was prohibited (Gasco 2005).

In Pipil society, there was a main god and temple for each altepetl, with lesser gods in each calpolli and most households (Lockhart 1992; Verhagen 1997). It was believed that the god of the altepetl gave his/her followers land and gave the nobles power (Lockhart 1992). Priests came from the same lineage as the nobles, and were sometimes the same people (Fowler 1989; Lockhart 1992). Maintenance of the temple and performance of rites and festivities were rotated monthly around the calpolli, with the priests in charge of the temple (Berdan 2005; Lockhart 1992; Verhagen 1997).

Priesthood was not just for men, as women were allowed to become priestesses (Berdan 2005). They had the same responsibilities as men (cleaning the temple, offering incense, and participating in ceremonies), but they also spent a lot of time weaving and embroidering cloths for the temple (Berdan 2005).

Everyone in society had a role in pre-Columbian religion. Below the priests were assistants who cared for sacred objects (Berdan 2005). The tlatoani had to assure religious ceremonies took place and sometimes participated in those ceremonies, as they 
were usually political events as well (Berdan 2005). Ordinary citizens also involved themselves, usually because they believed they could gain favor of the gods by serving in the temple (Berdan 2005). Many professions had deities associated with their profession, and people were required to participate in the festival appropriate to their profession (Berdan 2005).

\section{ARCHAEOLOGICAL PATTERNING OF RELIGION}

Archaeological evidence for preconquest religion could be found as the remains of many temples, as each altepetl had its own (Fowler 2006; Sampeck 2007), and the preconquest temple for Caluco has been located (Sampeck 2007). The sacrificing of victims to appease the gods was an important aspect, so a multitude of human remains around the temples could be another piece of evidence (Barnadas 1984), but others dispute the presence of bodies under church floors as resulting from sacrifices (Sampeck, personal communication 2015). Also, the discovery of indigenous books detailing rituals is yet another example (Ethnohistory Winter 2015), while Fowler (1985) used ethnohistoric sources written by Spanish who saw and interviewed the Indians regarding their religion.

In summary, everyone in pre-Columbian Pipil society had a role in the religious aspects of everyday life. Priesthood was open to every citizen, male or female, and nobles and commoners alike had the ability to affect the gods by their actions. Also, temples littered the landscape, as each altepetl had its own. 


\section{EUROPEAN EXPANSION}

While life was being lived in pre-Columbian society as described above, several European countries looked to expand their borders during the 1400s. Portugal was the first, with the seizure of Ceuta on the Straits of Gibraltar (Wolf 1982). Portugal was a very poor country, but gathered wealth through wheat and sugar production in the areas it claimed (Wolf 1982). The Netherlands' expansion grew out of its trade of grain, timber, metal, salt, cloth, and herring between the Baltic and Western Europe in the mid-1450s (Wolf 1982). France's expansion was different from other countries in that it just expanded its existing borders by ousting the English and winning over Aquitaine and Occitania (Wolf 1982). England's growth in the beginning was similar to the Netherlands in that trade helped it to expand; in this case it was wool (Wolf 1982). Meanwhile, Spain's expansion was linked to its reclaiming of the Iberian Peninsula (Wolf 1982).

\section{SPAIN BEFORE THE CONQUEST}

Several events in Spain led to the colonization of the Americas. The Romans had control of the Iberian Peninsula, which they called "Hispania," until they were overrun by the Visigoths (Gasco 2005). This led to the colonization by the Moors in the early 700s A.D. (Gasco 2005; Verhagen 1997; Wolf 1982). While most of the population converted to Islam after the arrival of the Moors, there was still a sizable population of Christians and Jews, the former of which desired to reclaim the peninsula (Gasco 2005; Wolf 1982). The result was a 700-year long reconquista, where Christians and Moors both tried to take control (Barnadas 1984; Gasco 2005; Gosden 2004; Wolf 1982), and resulted in the 
unification of the crowns of Castile and Aragón (Wolf 1982). Gasco (2005) states that, originally, the animosity between the two groups (Muslims and Christians) was not related to religion, but for the right to use agricultural lands. Resettlement was a practice used in Latin America that had its beginnings in Spain: when a community of Moors was overtaken by the Christians, the Moors were driven out and a Christian community resettled the land (Gasco 2005; Barnadas 1984).

The struggle became holy when Muslims arrived from North Africa (Gasco 2005). "Spanish nationalism and religious intolerance" reached a high point with the 1469 marriage of Ferdinand to Isabella, the "Catholic Kings" (Gasco 2005:77-78; Verhagen 1997). The crown grew stronger as it took control of formerly free municipalities, sought out alliances with other European royalty, and banished Muslims and Jews from the Iberian peninsula in 1492 (Gasco 2005). In the 1490s, Spain grew more interested in North Africa, as it was believed that Morocco posed the greatest threat to Spain and Christianity (Barnadas 1984; Gasco 2005). Gosden (2004) states that reconquista provided both a model to follow for conquest and a religious reason to do it. "Christianity and the purity of blood...were both concepts exported to New Spain, where they provided a justification of conquest..." (Gosden 2004:124). Because of Ferdinand and Isabella, the Catholic Church had become very powerful at this point and the king and queen used the reconquista to spread its influence (Verhagen 1997).

The children of Ferdinand and Isabella married into the Hapsburg dynasty, which helped "Spain's emergence as a major European power," and "reinforced the prestige of the monarchy (Gasco 2005:78). All of this, plus competition with Portugal, led to Spain's desire to expand (Gasco 2005). 


\section{SPANISH CONQUEST OF THE AMERICAS}

The first areas that Spain tried to conquer were the Canary Islands in the 1470s (Gasco 2005). There, the same policies employed in Spain were used: Ferdinand and Isabella claimed authority over the territory and gave the conquistadors the rights to whatever they had overtaken during the conquest, or encomienda (Gasco 2005:79). And in 1492, the crown granted the voyage of Cristobal Colón, who wanted to forge a new route to eastern Asia (Gasco 2005; McAlister 1984).

Colón's voyage initiated the formation of several Spanish settlements in the Caribbean and Panama, but the crown was displeased with these because they did not lead to much gold (Gasco 2005). Spain realized the opportunities present farther west, which led to Hernán Cortés's explorations in Cuba and Mexico and victories over the Aztec empire in 1519 (Gasco 2005; MacLeod 2008). What Cortés did in the New World was a continuation of the reconquista (Gosden 2004; Wolf 1982), and it strengthened the power of the crown within Spain (Wolf 1982).

\section{CENTRAL AMERICA}

Guatemala was particularly hard-hit during the Spanish conquest of the 1520 s (MacLeod 2008). Pedro de Alvarado turned Guatemala into a land full of Spaniards, with few Indians, and little gold or silver, as it had mostly been sent back to Spain (MacLeod 2008). His frequent departures with resources left the land barren for when he next returned for capital to finance his endeavors (MacLeod 2008). This left even the Spanish in Guatemala in poor standing (MacLeod 2008). 


\section{IMPACTS OF SPANISH INVASION}

Changes the Spanish brought include a reorganization of society (policía), with all natives lumped together as "Indian," and all the Indians beneath all Spanish (although there were different categories of Spanish — conquerors and descendants, then the middle class, followed by the poor) (Wolf 1982). There were commoners, nobility, and slaves in pre-Columbian society, but with the Spanish, the Indians became the slaves (Fowler 2006; Verhagen 1997). Colonial society in Central America was not stable: the different levels of Spanish society were often antagonistic towards each other (Wolf 1982), and the introduction of new diseases to the area wiped out large numbers of the indigenous population (MacLeod 2008; Wolf 1982).

The Spanish unknowingly spread diseases throughout the Caribbean and Central and South America, with smallpox, measles, and malaria being some of the most prevalent (Wolf 1982). The population of Caluco was reduced from 700 tributaries to 60 by 1584 (MacLeod 1984: 92). During this time, 14 epidemics (and 17 in the Andes) spread throughout Mesoamerica (Wolf 1982). The restructuring of the Indians into labor forces for the Spanish made these diseases spread easier in some areas, Izalcos being one of the hardest hit regions because of the strength of its cacao production (MacLeod 2008).

Cacao was a tribute item in pre-Columbian society (Fowler 2006; Sampeck 2007). Cacao was a luxury, and evidence of cacao beverages has been found throughout Mesoamerica (Fowler 2006; Sampeck 2007). The Izalcos region of El Salvador was particularly proficient at cacao production, and cacao itself was used as money, so large 
numbers of Spanish encomenderos, priests, and officials were drawn to the area (Fowler 2006: 310). The wealth cacao provided led to the construction of impressive churches, but the diseases that hit El Salvador between 1520 and 1577 reduced the population so much that the residents of Izalcos could not keep up with tribute demands (Fowler 2006; Wolf 1982).

Another policy that had a large effect of the region was encomienda. Encomiendas were granted to Spaniards to reward them for their role in the conquest (Lockhart 1992). In the encomienda system, Indians were forced to work on plantations for little pay (MacLeod 2008). This was a practice taken directly from Spain (Verhagen 1997), where adelantados, or military leaders, rewarded themselves with land and slave labor after claiming land (Gasco 2005; Gosden 2004; Wolf 1982). Besides pay, it differed from slavery in that the workers were not uprooted from their homes and fewer died as a result (MacLeod 2008).

The idea of encomienda came about because privately-owned lands were becoming more prevalent in Spain at this time (MacLeod 2008). The best encomiendas were taken by the conquistadors, and they gave the others to their friends, families, or allies (MacLeod 2008). When a small tract of land was purchased, the Spaniards many times would fence off more land than they had purchased (Fowler 1993).

The crown did not approve of encomienda being practiced overseas because it was afraid of a powerful class of encomenderos arising, but as the Indians would not work for the Spanish in any other way, it relented (Verhagen 1997). In addition, the settlers proved to the crown that the system was the only way to make the area 
productive, and the crown needed some way to reward its settlers (McAlister 1984; Verhagen 1997).

\section{ARRIVAL OF THE CLERGY}

The first clergy members came to Latin America with the conquistadors to serve them and to end abuse of the Indians (MacLeod 2008), which included slavery or death, sometimes immediately after they were baptized (Clayton 2011).

What also brought the clergy to the area were the Papal Bulls, issued by popes Alexander VI and Pius III from 1493 to 1508 (Barnadas 1984; Verhagen 1997). The laws allowed the Spanish crown, and not the Catholic Church in Rome, to direct the evangelization efforts in Latin America, collect tithes, and appoint whomever they wanted to positions within the church (Barnadas 1984; Verhagen 1997). In 1521 and 1522, more Papal Bulls were issued by Leo X and Adrian VI (McAlister 1984; Verhagen 1997). These laws allowed for the Franciscan, Dominican, and Augustinian missionaries to administer sacraments, be protected from excommunication, and to provide the churches with ministers (McAlister 1984; Verhagen 1997). The two popes intended for the missionaries to stay only temporarily before passing on their roles to the secular clergy (Barnadas 1984; Verhagen 1997). However, this led to the establishment of more permanent manifestation of missionaries in the region (Verhagen 1997).

Within Spain, the crown was only allowed to nominate individuals to become bishops (Barnadas 1984; Verhagen 1997). These rights were known as the Royal Patronage, and the only things the Spanish crown had to do in return were to convert the 
Indians and protect the church (Barnadas 1984; Verhagen 1997:81). The encomienda system was used to accomplish this.

Encomenderos were required to instruct their Indians in Christianity, so they urged secular clergy to move to the region (Van Oss 1986). Secular clergy was preferred over the regular clergy because the secular clergy did not care much about the Indians' wellbeing (Verhagen 1997). The secular clergy did not have to make vows of poverty like the regular clergy, and were not sent by the Crown (Van Oss 1986; Verhagen 1997). Because of the wealth cacao production provided Caluco and the Izalcos region, the secular clergy had no reservations about moving to the area, as they typically preferred moving to rich areas (Verhagen 1997). The clergy was incompetent, and mainly was there for financial gain than to instruct the Indians (Verhagen 1997).

Starting in the 1520s, doctrinas de indios, or Indian parishes, were established by the missionaries (Lockhart 1992; Verhagen 1997). In some cases, one encomienda would be split into smaller parishes, while in others the parish consisted of two associated encomiendas (Lockhart 1992). More common, however, was that the parish was "simply a function of the encomienda," where the parish depended on the encomienda for support (Lockhart 1992:28). The doctrinas were used by missionaries to teach, monitor for idolatry, and organize the social lives of the Indians (Verhagen 1997). In the 1530s, though, Catholic missionaries began arriving solely to convert the Indians to Christianity (MacLeod 2008). The missionaries settled in the Indian villages and continued trying to stop the abuses of the Spanish (MacLeod 2008). 
Missionaries who did not settle in already-formed Indian villages used the policies of reducción and congregación (the relocation of Indians into "ordered towns" in order to missionize them) to their advantage in their evangelizing efforts (Hanks 2010; Jackson 1995) to bring the residents to them. The clergy argued that Christianizing the Indians would not be possible if they were not all in one place (MacLeod 2008). Begun in 1543, the purposes of reducción and congregación were to instruct the Indians in Christianity, control labor, and make tax collection easier by "congregating" the Indians into urban areas to reduce travel time for the friars whose job this was (MacLeod 2008; Verhagen 1997). A disastrous effect of this was that the Spanish thought having the Indians in one area would make treating illnesses easier, but instead congregaciones caused epidemics to wipe out large numbers in these newly-created urban areas (MacLeod 2008).

Spanish towns in Latin America were compact, had administrative, religious, and residential buildings close together, and were organized "around an orderly pattern of streets" and a central plaza, all of which were constructed by the Indians (MacLeod 2008; Palka 2009; Van Oss 2003:170-171; Verhagen 1997). Streets were constructed to run north-south and east-west from the plaza, where the central plaza and town hall were located (Fowler 2006). Friars used the Indian labor available in the congregación to construct the town, including the church buildings that were present in each congregación (MacLeod 2008). The grid pattern was not as easy to use at Caluco as elsewhere because of the topography, but was still applied (Verhagen 1997).

Congregación was only practiced for a short time in some areas - it was over by 1550 in Mexico (MacLeod 2008), but re-emerged as a policy in the eighteenth century as 
part of the Bourbon reforms by the Spanish monarchy (Dym 2006, 2007). The archaeological evidence indicates that congregación towns in Izalcos were not occupied significantly until at least the 1580s (Sampeck 2007). During its period, congregación was not necessarily easy for the Spanish to accomplish. While some Indians moved willingly, others moved much less willingly, and others still resisted until they were threatened (MacLeod 2008). After 1550, plenty of land was available for the Spanish to claim as there were fewer Indians, and the small Indian populations lived in colonial Indian pueblos (MacLeod 2008). Religion, demography, and urbanism are all interrelated in that the population was relocated to urban areas and forced to convert to Catholicism.

\section{CALUCO, EL SALVADOR}

Caluco is a municipality in the Sonsonate department of El Salvador, and located in the Izalcos region. The conquest of the Izalcos region began in June 1524, with Pedro de Alvarado and between 5,250 and 6,250 troops (Fowler 1991, 1993; Verhagen 1997). Eight years after that initial contact, the four towns of the Izalcos region were given as encomienda, Caluco included (Verhagen 1997). Encomenderos were drawn to the Izalcos region because of its rich production of cacao (Fowler 1991, 1993, 2006; MacLeod 2008). Caluco was originally given to only one encomendero, but was given to two different encomenderos after the first died (Verhagen 1997). The Crown either took over encomiendas or split them up after the original encomenderos died because it was afraid that the encomenderos were going to turn their encomiendas into "private feudal kingdoms" (MacLeod 2008:128). The Izalcos region was deemed particularly corrupt because the indigenous did not follow strict Christian order, so the encomenderos 
practiced an "extreme" form of congregación and did not allow the Indians to leave town (Sampeck 2015:10-11).

Construction of the church in Caluco, San Pedro y San Pablo, began in 1567 and was completed in the early 1600s (Fowler 2006). Parts of the church included the main church of San Pedro y San Pablo and four chapels (Verhagen 1997), and it was built in a Spanish American mudéjar Muslim style (Fowler 2006). Five masses per week were conducted, as were services and feasts during the sixty-five holy days each year (Verhagen 1997). The church is no longer standing, having been destroyed by two earthquakes, one in 1773, and the other in 2001 (Fowler 2006).

\section{ARCHAEOLOGY IN CALUCO}

Archaeological excavations were carried out at San Pedro y San Pablo in 1993 1994 by Dr. William Fowler, Inez Verhagen, and ten undergraduate students at Vanderbilt University (Verhagen 1997). Larger excavations covered the eastern and northern sections of the church, with smaller pits in the western section (Verhagen 1997). Fields Q and R were excavated (auger tests, surface collections, test pitting, and large excavations) from March to May 1994, and Fields S, F, K, and N were from October 1994 to May 1995 (Verhagen 1997). Sampeck (2007) also excavated (three 2x2 m units southeast from the town square and San Pedro y San Pablo) and surveyed Caluco in 1994-5.

Several books on church construction (Fowler 1995); dissertations on the political economy, history, and make-up of the town (Sampeck 2007; Verhagen 1997), and book 
chapters regarding cacao production and tribute (Fowler 1991; 1993; 2006) have covered many aspects of historical archaeology in Caluco, El Salvador.

\section{SUMMARY}

Pre-Columbian society was complex even before the conquest. The Spanish compounded this in a variety of ways, only some of which were unintentional (such as population decimation by diseases). Just as vast as the region's history itself is the wealth of information that has been published by archaeologists and historians alike, which will be discussed in the next chapter. 


\section{CHAPTER II}

\section{REVIEW OF THE SCHOLARLY LITERATURE AND THEORETICAL FRAMEWORK}

The study of Catholic missions everywhere, whether through history or archaeology, was largely ignored until about the mid-1980s (Jackson 1995). When they were studied, most of the work was completed by those within the Church who presented the missionaries as heroes or saints and the Indians as barbarians (Jackson 1995; Shea 1969). More attention has been given to the plight of the Indians since the 1980 s and has typically been written as apologies for the Church (Jackson 1995).

While historians have focused on the European perspective using documents, archaeologists have used material culture to study native responses, although this has mainly been on mission sites in the US (Florida, Texas, California, and New Mexico) (Graham 1998; Shea 1969). Research in Mesoamerica has focused on architecture or pre-Columbian archaeology (Graham 1998).

There is the view that Christianity is European and has not changed in its history, but Christianity in Europe was influenced by indigenous European culture (Graham 1998). Likewise, indigenous Mesoamerican culture influenced Christianity both at home and abroad Graham 1998). Graham (1998:30) states that it is important to note that 
Europeans have no "claim to knowing Christianity any better than Native Americans," nor do they "experience Christianity in any superior way."

\section{HISTORICAL RESEARCH}

Many contemporary historical sources discuss the colonial period in Latin America (Brown 1996; Chuchiak 2007; Overmyer-Velázquez 2005; Peel 1995; Restall 2003; Stear 2014). Some areas of study include the conquest, with emphasis on the conquistadors. Topics focused on who the conquistadors were and their motivations for coming to the New World, how they interacted with the Indians, and the myth set forth by the Spanish of their superiority (Restall 2003).

Other areas focused more specifically on the Church during the colonial time period, in different areas of the region, such as central Mexico (Stear 2014) and Peru (Llerena 2014). Historians with a focus on religion studied resistance to missionization and colonialism using native-written sources, in this case historical codices that documented conflict and accommodation that was written by Nahua elites who were under the instruction of Franciscan friars (Stear 2014). Misunderstandings of Native American religions by the Spanish and English caused colonial-period writers to equate the religions with paganism and Satanism, which was then used to justify atrocities committed against the practitioners (Bauer 2014). Also, the study of native sources has led to a better understanding of how the indigenous viewed the colonial experience (Llerena 2014) and the relationship between members of the clergy and natives (Chuchiak 2007). In addition, Bethell's 1984 work covered Mesoamerica and Europe 
before, during, and after the conquest, along with a section about the Catholic Church in America.

\section{ARCHAEOLOGY OF COLONIAL ECCLESIASTICAL SETTINGS}

Most of the work about colonial ecclesiastical settings of the Spanish and in Latin America has focused on missions (Graham 1998). Popular areas of study include the American Southeast, mainly Florida, and the Caribbean (Deagan 1978, 1988); the American Southwest (Adams 1989); Texas (Hester 1989); California (Allen 2010; Costello and Hornbeck 1989); Honduras (Weeks and Black 1991); Yucatan (Pendergast 1991); and Peru (Wernke 2010). All of these examples listed above regard Spanish missions, but archaeologists have also been interested in missions of other countries, such as French missions in the Great Lakes region (Nassaney 2008).

Topics of study within mission archaeology have involved resistance, such as resistance by abortion and infanticide (Costello and Hornbeck 1989). Allen (2010) researched the ways the Indians of the California missions made use of the lands in between the buildings on their mission.

Resistance has not been the only focus on missions. One other such topic was acculturation, with this being applied to missions in Peru (Wernke 2010). The Mercedarian missions in Honduras were particularly good at organizing indigenous labor in areas not immediately clustered around Spanish towns (Weeks and Black 1991). In Belize, the Maya used a variety of techniques to resist Spanish policies, but at the same time adapted elements of Christianity because they noticed parallel views that could be conformed into their existing belief systems (Pendergast 1991). 
Another area where the majority of research about colonial ecclesiastical settings has been focused is the architecture of church buildings (Van Oss 1986; Verhagen 1997). Van Oss (1986), an architectural historian, researched parish churches in Guatemala, while Verhagen wrote her dissertation (1997) about the church at Caluco, San Pedro y San Pablo, but she was studying architecture and the amount of acculturation, not resistance.

\section{ARCHAEOLOGY OF COLONIALISM}

The archaeology of colonialism has spread all over the globe, like colonialism itself, with many research interests: One such interest was the changes colonialism caused in the political economy of different regions of the world. One example included trade, which was used to control indigenous communities in Iraq (Gosden 2004; Stein 1999, 2005). Cacao being introduced into trade during the colonial period directly influenced the economy in Soconusco, Mexico (Gasco 1992). Also, Indians at three mission sites in Alta California were able to retain a great deal of their traditional culture, but where changes did occur, it usually involved changes in the economy (Farnsworth 1992). And the response of tenant farmers influenced the political economy of nineteenth-century Ireland (Orser 2005).

Another area of research was to look at indigenous responses to colonialism. In Hueda and Dahomey, West Africa, the Africans of those two towns understood the benefits of contact with Europeans and used this to their advantage (Kelly 1999). Also, a result of colonialism in Africa was the production of low-fired, coarse earthenwares that were then recreated when West Africans were shipped to the United States during the 
slave trade (Kelly 1999). Another response to colonialism was the formation of new social classes (Wood 2012). One of these was freepersons of color in the Virgin Islands, which split the divide between "whites" and "black" slaves (Wood 2012).

Other aspects of colonialism that have been studied include material culture, such as coarse earthenware pots in South Africa and how the production of these reveals social relations (Jordan and Schrire 1999). Also, African scarification on bodies in Africa that were then used as decorations on ceramic vessels in Brazil, which signifies the construction of new identities of slaves in South America, has been popular to study in recent years (de Souza and Agostini 2012).

There have been other realms of research regarding colonialism not focused specifically on artifacts. Self-marginalization of Aonikenk hunter-gatherers in Argentina allowed them to adapt in ways they chose themselves in response to colonialism (Delaunay 2012). Native Andeans constructed new towns in Peru in response to colonialism (Cummins 1999). Also, Given's (1994) work covered indigenous experiences in Egypt, Scotland, Turkey, and Cyprus.

\section{ARCHAEOLOGY OF RESISTANCE}

The archaeology of resistance has been a popular area of study for archaeologists, but usually this focus has concerned African-American slaves. Brazil has been a popular area to study, especially the maroon communities that resulted from slaves fleeing conflict (which is a form of resistance) (Flory 1979; Orser and Funari 2001; Weik 1997). Maroon communities also sprouted in the Caribbean (Agorsah 1993) and Florida (Baram 2012), 
Using goods, resistance was achieved through the illegal trade of majolica in Florida (Deagan 2007; Thompson 2012). African slaves in South Carolina resisted the harshness of slavery by the continual use of colonoware, even though European-style wares were provided for them (Groover 1994; Ferguson 1991; Lees and Lees 1979; Matthews 2010). Another time period is post-Civil War and the resistance of sharecroppers and tenant farmers against their former owners in the Southeast (Orser 1991).

Other archaeologists have looked at resistance by Native Americans in the United States. One such place was Fort San Juan in western North Carolina, but the archaeologists who worked at the site say that they believe studying resistance there is too restrictive a topic at Fort San Juan because not only were the Spanish taking advantage of the Indians, the Indians were taking advantage of the Spanish (Beck et al. 2010). Deagan's (2010) research focused on the first acts of resistance to the Spanish by Native Americans. Some of this work focused on church settings, and Deagan states that resistance here took the form of either rejecting or transforming Catholic rituals to fit the Indians' tastes, and that European and indigenous artifacts were found in graves in church cemeteries (Deagan 2010). Saunders $(2001,2012)$ found that in response to missionization the Guale created a new type of ceramic.

Most archaeologists studying resistance in Spanish America have focused on other forms of technology besides ceramics and not church settings (Bamforth 1993; Rodríguez-Alegría 2008). Fowler's 1991 work focused on resistance through the continuity of pre-Columbian economics and social structures in the Izalco region specifically, but in regard to the political economy. Other archaeologists' research in 
Latin America has focused on the formation of Indian groups to resist Spanish presence in Honduras: the Pech were quite isolated geographically from Spanish influence (Davidson 1991), and warlike societies were formed that were able to circumvent the colonial regime in northeast and mideast Honduras (Pinto 1991).

Another method was the use of writing as a form of resistance, and this approach was practiced by several groups, such as the Cakchiquel Maya (Hill 1991) and Yucatec Maya (Chuchiak 2010). Also, the criollos in the Basin of Mexico used ceramics to resist the Spanish Crown taking away encomiendas (Charlton and Fournier 2010). In this case, it was the application of an "R" on indigenous ceramics (Charlton and Fournier 2010).

Other areas outside of Mesoamerica include Peru, where resistance was detected in the reburial of the dead at night when no members of the clergy were present (Murphy et al. 2010). Another area of resistance has focused on the southwestern United States (Liebmann 2010); including resistance and fighting between the Pueblo and NavajoApache (Preucel 2010) and at the military site of El Presidio de San Francisco (Voss 2010).

Some archaeologists, however, have researched church sites in Central and South America, but in places other than El Salvador. Graham (1991), Hill (1991), and Pendergast (1991) focused on sites in the Maya region and found that the Maya both resisted the Spanish and blended elements of native religion and Catholicism. Other areas and topics include acculturation on several church sites in Mexico and other regions of Mesoamerica (Palka 2009), cofradías at a Mercedarian missionary church in Despoloncal, Honduras (Sheptak et al. 2010), houselots on two seventeenth-century 
religious structures at Sahcabchén, Mexico (Alexander 2005), and resistance to religion in Peru (Quilter 2010).

\section{ARCHAEOLOGY OF THE $16^{\mathrm{TH}}$ TO $17^{\mathrm{TH}}$ CENTURY IN SPANISH AMERICA}

In the 1980s, Andrews (1981) published an overview of the historical periods in Latin America, with a listing of chronological periods and sites. Earlier than that, Service (1955) explored Indian-European relations in colonial Latin America. Recent work on Spanish America has focused on economic and societal changes to the region during colonization. Gasco researched this phenomenon several times, with her work on settlement patterns and households during the colonial period in Chiapas, Mexico (1992), and then again with economic changes in Soconusco (Gasco 1993). In the same volume of work, Fowler (1993) researched societal changes in Izalco, El Salvador. Also, some have researched the impact changes in lifestyle had on the economy and society, such as what changes in food influenced changes in society, set at the nineteenth-century Hacienda San Miguel Acocotla in central Mexico (Newman 2010).

Other topics included more of a focus on materials to research societal changes, like those listed above. One such example was the adoption of Spanish materials (clothing and majolicas) in Xaltocan, Mexico (Rodríguez-Alegría 2010). These were adopted by two social groups of indigenous people: the elites who adopted Spanish clothing that marked power, and commoners who used Spanish ceramics to undermine power structures (Rodríguez-Alegría 2010).

Not only did the indigenous and slaves adopt ideas and materials from the Spanish, but the Spanish adopted ideas from the indigenous and slaves as well. McEwan 
(1992) looked at ceramic and metal artifacts in both Spanish America and Spain itself to determine environmental, economic, and demographic changes in both areas. She found that the Spanish were more likely to be accepting of societal changes than they were of changes to their foodways and material goods (McEwan 1992). Also, McEwan (1991) used domestic contexts to determine the influence of women in the sixteenth and seventeenth century throughout Spanish America (McEwan 1991). Artifacts related to the slave trade in Panama showed how slaves were able to influence their captors in the adoption of artifacts, in this case, ceramics and beads (Ammann 2012). The Rio Grande River Valley provided a different perspective, in that the Indians maintained the use of their material culture, while the Spanish adopted it, in this case only because there was a shortage of Spanish materials (Rothschild 2006).

\section{SPANISH ARTIFACTS IN THE COLONIES}

Several comprehensive guides to artifacts found in Spanish sites in the New World have been published. One of these is Deagan's 1987 work that focused on ceramics, glass, and beads. Others include Lister and Lister's 1976 publication regarding 500 years' worth of Spanish ceramics, which defined and described hundreds of methods, forms, types, and decorations of Spanish-style wares made both in Spain and Latin America. In addition, their 1974 work published in Historical Archaeology detailed specifically majolica found in Latin America. Also, Cohen-Williams (1992) summarized majolica types found in New Spain and Jamieson (2001) did the same for Panamanian majolica in the Andes. 


\section{THEORETICAL FRAMEWORK}

Several theories have been applied to research in Latin America in the past. This chapter will outline a few of those theories and describe why they do not apply to my research. It will then describe the theories I have used in writing this thesis. The two approaches I have used are Marxian and practice theories, which are beneficial because they explain how people responded to conflict in a way that does not use categories or mathematical formulas, as critiqued below.

\section{Cultural Change}

In 1992, Farnsworth invented a technique for determining the rate of cultural change on California missions. He took Quimby and Spoehr's 1951 “categories of culture change," which concerned museum collections and only artifacts that displayed some evidence of cultural change (Farnsworth 1992). Farnsworth (1992) increased Quimby and Spoehr's categories from seven to 10, and included European objects that directly replaced Indian objects, Indian objects without any modifications, and Indian objects made from local materials using European techniques. He took a standardized approach and included formulas for determining the rate, and his examples from the California missions have "percentage of continuity of traditional cultural elements" and "percentage of intensity of cultural exchange" (Farnsworth 1992:29). These formulas were then used to determine if the resulting culture was a hybrid or not (Farnsworth 1992). This is not the best way to study Latin America because all areas did not experience colonialism in the same way and cannot be summed up using a mathematical 
formula, but would appeal to those wanting a simple way to compare several contexts at once.

\section{Creolization}

In 2000, Charles Ewen compared creolization to acculturation and used the theory of "conquest culture" to describe what played out in Puerto Real, Haiti. Conquest culture identifies one culture as the recipient and the other as the donor, with three types of processes: 1) intentional changes directed by authority; 2) informal changes directed by the Spanish colonists; and 3) ways the Spanish modified their existing culture (Ewen 2000).

My problem with conquest culture is that it focuses too much on the colonists and not enough on the colonized, except that they adopted elements of the colonists' culture. It does not explain any processes in which the colonized kept elements of their own cultures, and does not even mention any conflict at all, which I think has a big part in what elements are adopted and what is not. I understand Ewen's theory is called “conquest culture," but I think "conquest" should apply to the time in history and not have the "conquesting culture" be the sole focus of the theory.

Dawdy's (2000) definitions of creolization and acculturation are stronger than Ewen's because she notes that the German, Spanish, and French settlers of Louisiana did indeed influence native Louisianans, but more importantly, these settlers adopted cultural elements themselves. In her definition, the native culture is the dominant culture (Dawdy 2000). 


\section{Transculturation}

Garman's (1998) work with African American slaves in New England acknowledged the issues Ewen's theory of “conquest culture” left out. Garman (1998) noted that other archaeologists have replaced "acculturation" with "transculturation." Acculturation is too one-sided and assumes that only the colonized changed culture. Transculturation acknowledges that cultural exchange alters both groups (Garman 1998).

Palka (2009) discusses transculturation at several colonial sites in Mesoamerica. He states that native peoples, while adopting some cultural elements, retained multiple indigenous lifeways (Palka 2009). One of the areas he mentions is El Salvador, and he notes that while Spanish architecture and settlement patterns (and ceramics, metal, and glass) become more prominent, the construction and materials used were usually indigenous (Palka 2009).

\section{Resistant Accommodation}

Along the same lines as transculturation is "resistant accommodation," which notes the roles of both slaves and masters in cultural exchange (Garman 1998). "African Americans were able to maintain elements of African and West Indian identity while taking on certain cultural aspects demanded by their Yankee masters... It created a continuous cycle of give-and-take and generated a constant drawing, contesting, and negotiating of power between masters and slaves" (Garman 1998: 135-136). An acculturationist would only see the subordinate group's adoption of their oppressor's culture, while someone using the domination-resistance model would be able to look at the conflict and see how both groups were affected (Garman 1998). 


\section{My Theoretical Framework}

The theoretical approaches that I have used are Marxian theory and practice theory. Marxian theory is appropriate because it deals with conflicts, and it has been used quite extensively in Latin America. Practice theory is useful because it explains how people lived in and worked around inequalities.

\section{Marxian Theory}

Marxian theory deals with conflict within the relations of production, and the relations of production are specifically the social relations (Friedman 1974). This fits in with my research as I have looked at how the Indians of San Pedro y San Pablo handled conflict with the Spanish of the church and compared this data with the relations of production on the privately-owned lands of Caluco.

Marxian theory has had a long history in Latin America, which saw its beginning with the Marxist revolutions in the late 1950s and early 1960s (McGuire 1993). The first Marxian archaeology was practiced in Mexico and Peru, and focused on the prehistoric periods (McGuire 1993). Conflict grew between the approaches of Latin American archaeologists and U.S. archaeologists (McGuire 1993).

Several anthropologists have used this approach in recent years. Eric Wolf (1982) did in Europe and the People without History, although he was not just looking at Mesoamerica but the whole globe during the colonial period.

Within Mesoamerica, Jones and Pendergast (1991) used Marxian theory while examining encomiendas. The Maya put to work on these encomiendas used two 
approaches to resist their situation: they fled the area when they could and also continued the practice of their native religion instead of adopting Catholicism (Jones and Pendergast 1991).

Marxian theory has already been applied the Izalcos region in terms of the relationship of the forces of production (Fowler 1991). In Fowler's 1991 work, he discusses Marxian theory in regard to the secular clergy, but not of the Church itself. Also, he found that the indigenous were able to maintain their traditional modes of production to meet the growing demands of the cacao industry during the colonial period (Fowler 1991).

Weeks and Black (1991) discuss Marxian theory in the context of encomiendas, this time in western Honduras. At this site, the secular clergy were in charge of the Indians of the encomiendas, so they had a direct relationship and thus the forces of production (Weeks and Black 1991).

Even more recently, Rodríguez-Alegría used Marxian theory in his studies about tool production in Xaltocan, Mexico (2008) and the adoption of Spanish material culture, also in Xaltocan, Mexico (2010). Chipped stone tool production continued even with the introduction of steel knives as a way for the indigenous of Xaltocan to resist the Spanish (Rodríguez-Alegría 2008). In the latter case, the adoption of Spanish materials was used to subvert Spanish power structures (Rodríguez-Alegría 2010).

Specifically in church contexts, Graham (1991) used Marxian theory in her examination of artifact change and continuity in Tipu, Belize. Marxian theory was also employed in the study of the production of ceramics at the Colonial church in Lamanai, 
Belize (Pendergast 1991). In addition, it was used to study the construction of churches in Belize and the Yucatán during the Colonial Period (Andrews 1991). And Chuchiak (2007, 2010) employed Marxian theory when he researched the social relations between Yucatec Maya and Franciscan friars and writing as a form of resistance used by the Maya against the friars.

Practice Theory

Practice theory is a fairly new theory in archaeology (Orser 2004), but is appropriate to use in my research because Stephen Silliman (2001) states that it is a way to think about how people negotiate the social conditions of their inequalities. Ortner (1984:149) defines practice as "anything people do," and states that the most significant kinds of practice involve political implications, both intentional and unintentional. Silliman (2001) used practice theory to show that the Native Americans of Rancho Petaluma continued their lithic practices through the colonial period. He formulated several hypotheses about why traditional lithic practices were used, and concluded that it was because lithics were how the Native Americans negotiated the terms of colonialism (Silliman 2001).

Practice theory was used in research on Native Californian women and Native Alaskan men at Fort Ross, a Russian community in California (Lightfoot et al. 1998). The people there forged their own identities in this pluralistic society (Lightfoot et al. 1998). There was tension and inequality in the community, as the Alaskan men did not trust the Californian women (Lightfoot et al. 1998). Also, practice theory has been used to study pottery changes at Cahokia during the pre-Columbian period (Pauketat 2001). In 
Pauketat's (2001:85) article, he states, "Mound construction itself was part of the 'political' negotiation process," and that accommodation and/or resistance is what led to construction events and technology changes. And Orser (2004) used practice theory to study racialization in nineteenth-century rural Ireland.

\section{Summary}

I have criticized conquest culture as being too one-sided, so why have I utilized two theories that appear to do the same thing? Creolization, acculturation, and conquest culture can and should be applied to both sides of colonialism, but Ewen did not look at both sides with his research at Puerto Real, Haiti. However, Marxian theory and practice theory are specific to the colonized, and especially geared to the inequalities the subjugated groups faced, which is the main focus of my thesis. Ewen's work can benefit my study, as I do look at the adoption of Indian ceramics by the Spanish, but as the focus is more on resistance by the Indians, Marxian theory and practice theory are more beneficial. Using these two theories, I expect to find evidence of resistance regarding ceramics, specifically more indigenous ceramics at the Pipil-occupied church and more European ceramics at the Spanish-occupied houses. A summary of each type of ceramic, either adopted by the Spanish or maintained by the Indians of Caluco, follows in the next chapter. 


\section{CHAPTER III}

\section{METHODS OF ANALYSIS}

Analysis of resistance at Caluco was conducted by comparing the ceramics from

the church, San Pedro y San Pablo, which was occupied by Pipil, to two privately-owned houses, Q and R, which were occupied by Spaniards, also from Caluco. The house Q was chosen because it had the most materials recovered from its boundaries than the other houses, and house R was chosen because I needed two. For all three locations, the materials were analyzed by looking at ceramic type, vessel form, and decoration techniques. Ceramic types were broken down by each individual type, but will be discussed in the analysis and discussion chapters broadly (coarse earthenware, majolica, refined ware). This was done to see if resistance could be determined using these attributes.

Most of my materials came from Verhagen's (1997) dissertation, but we focused on different questions and different scopes of area. She researched material and social changes for the whole of Caluco during the colonial period, specifically changes in wealth and status differentiation (Verhagen 1997). I am more specific in location, as I am looking for material changes to indicate resistance at the colonial church. 


\section{MATERIAL CULTURE OF ECCLESIASTICAL SETTINGS}

The analysis of form is very important as forms are different between the church and the houses, and some of these forms are quite common in Catholic churches in particular. Items used during church services, like stoups (pila de agua beneditas) which are urns filled with holy water found near church entrances, are expected to be made of ceramics but may also be found on other materials such as glass, metal, or wood (McEwan 1992). Liturgical cruets were another such vessel, and their function was to hold wine or water for the Eucharist (McEwan 1992). Other ceramic forms included ewers, candlesticks, and censers (McEwan 1992).

Other ceramic artifacts that were found on mission sites, but were not used during church services include tiles and tablewares (McEwan 1992). Rings or flat bottoms on vessels were Spanish forms found on mission sites as well, as were serving bowls with everted rims (Adams 1989; Saunders 2001). The presence of ecclesiastical material culture as defined above might show the extent to which Catholicism was adopted at Caluco, but these items might not have been used in the ways they were intended.

\section{HOUSEHOLD CERAMICS}

Ceramics expected to be found at the two houses included food preparation, storage, and serving vessels: similar to what is expected to be found at San Pedro y San Pablo, as people resided in all three locations. The only difference was I did not expect to find items related to Catholic worship services at either house, merely because I did not consider homes places of worship. 


\section{Earthenwares}

Most of the earthenwares were made locally (no European imports), although there were some Spanish imports. Earthenwares were expected to be found at all three sites, and the ones from the three sites in Caluco that I researched include fourteen types: Catalina, Pantaleón Plain, Pantaleón Brown, Teofilo, Raimundo, Dario, Apolonio, Telesforo Plain, Teshcal, Camilo, lead-glazed earthenware, lead-glazed redware, green lead-glazed earthenware, and olive jar (Sampeck 2007).

\section{Catalina Red-on-White}

Catalina Red-on-White vessels, a Postclassic and protohistoric type, have red pastes with no inclusions (Sampeck 2007; Verhagen 1997). Bowls are the most common form, and the vessels all have white slips with red geometric designs (Sampeck 2007).

\section{Pantaleón}

There are two types of coarse Pantaleón wares, and both date to the late $16^{\text {th }}$ and $17^{\text {th }}$ centuries (Gillenwater 2013; Verhagen 1997). Pantaleón Brown wares have medium brown to buff pastes with pumice inclusions (Sampeck 2007). These vessels, when decorated, usually just had a red wash applied to the surface (Sampeck 2007). The paste of Pantaleón Plain wares can be dark brown or beige, and usually has dark red inclusions (Gillenwater 2013; Verhagen 1997). Common forms of both types include comals and ollas, which were used as cooking pots (Verhagen 1997). 


\section{Teofilo}

Teofilo vessels have medium brown, buff, and sometimes dark cores (Sampeck 2007). Hemispherical bowls are the most common form, and vessels are usually decorated with a thick and waxy red slip, which separates them from Pantaleón wares (Gillenwater 2013; Sampeck 2007).

\section{Raimundo}

Raimundo vessels appear sometime in the early $17^{\text {th }}$ century and nearly replace Pantaleón (Verhagen 1997). The paste of Raimundo vessels have dark gray cores and lots of large inclusions (Gillenwater 2013; Sampeck 2007). The surfaces are usually smooth, but striations from wiping can occur (Sampeck 2007). Comals are typical forms of Raimundo vessels, and no decorations have been noted (Sampeck 2007).

\section{Dario}

Dario ceramics are a colonial fine ware (late $16^{\text {th }}$ and early $17^{\text {th }}$ century) that have a light orange surface with lots of micaceous inclusions (Gillenwater 2013; Sampeck 2007; Verhagen 1997). Their cores are either light gray or white, and red slip is the most common decoration (Gillenwater 2013; Sampeck 2007).

\section{Apolonio Orange Red}

Apolonio Orange Red vessels, an early colonial period type, have tan to medium brown pastes with pumice inclusions (Gillenwater 2013; Sampeck 2007). They have orange-red slips with no other decorations, and bowls are the most common forms (Sampeck 2007). 


\section{Telesforo Plain}

Telesforo Plain vessels date from 1650 to 1800 (Verhagen 1997), and are typically big and thick: basins or ollas (Gillenwater 2013; Sampeck 2007). Both the surface and the paste are a medium brown, with sand inclusions in the paste and rough surfaces, having not been completely smoothed (Sampeck 2007).

\section{Teshcal Red-on-Natural}

Teshcal Red-on-Natural vessels, which date to the late $16^{\text {th }}$ to early $17^{\text {th }}$ century, have a buff to reddish-brown paste with inclusions (Sampeck 2007). The surfaces are buff as well, but with red geometric decorations (Gillenwater 2013; Sampeck 2007). Typical forms include molcajetes, bowls, and jars (Sampeck 2007).

\section{Camilo}

Water bottles appear to be a typical form of colonial Camilo vessels (Sampeck 2007). They have red pastes, small inclusions, and most seem to be red slipped (Sampeck 2007).

Olive Jar

Olive jar is also a colonial coarse earthenware, but differs from the types described above in that it is the only coarse earthenware that was not locally-made; in this case it was produced in either Spain or Peru (Sampeck 2007; Verhagen 1997). These are all large jars that were used to transport wine or oil (Sampeck 2007). 


\section{Majolicas}

Majolicas were analyzed using the same criteria as the earthenwares: type, form (I did not have access to 283 of the 285 sherds from San Pedro y San Pablo, but they have all been classified as having unidentified forms), and decoration. The fifteen majolica types found at the three locations in Caluco will be discussed in this section: Guatemalan Polychrome Variant A, Guatemalan Polychrome Variant B, Guatemalan Polychrome Variant C, Panama Plain, Panama Polychrome A, Panama Blue on White, Puebla Blue on White, Columbia Plain, Sevilla Blue on White, Sevilla Blue on Blue, Sevilla White, Mexico City Fine Grade, San Luis Mexico City Fine Grade, Yayal Blue and White, and Indigena ware (Deagan 1987; Lister and Lister 1974; Sampeck 2007; Verhagen 1997).

Majolicas started being produced in Guatemala around the 1580s (Sampeck 2015; Verhagen 1997). Guatemalan Polychrome Variant A vessels have coarse brick red pastes and a white tin glaze that varies in thickness on individual vessels (Sampeck 2007;

Verhagen 1997). Decorations are usually painted in yellow, black, brown, and green, but sometimes have blue (Sampeck 2007). Guatemalan Polychrome Variant B vessels have pink or orange pastes, which are also typically finer grained that Variant A pastes (Sampeck 2007). The colors of the decorations are similar to those of Variant A, as well (Sampeck 2007; Verhagen 1997), with blue decorations having been noted at Caluco (Sampeck 2007). Guatemalan Polychrome Variant C vessels have brick-red/brown pastes, thicker tin glazes, and similar decoration colors as Variants A and B (Sampeck 2007). 
The three types of Panamanian majolicas found at Caluco are Panama Plain, Panama Polychrome A, and Panama Blue on White. They have a similar dark red paste color as the Guatemalan majolicas, but are finer, which causes them to weather and become smooth (Sampeck 2007). Also, the white tin glaze is typically applied more uniformly on Panamanian majolicas than Guatemalan majolicas, causing the Panama ones to be whiter (Sampeck 2007). Panama Polychrome A decorations are similar to Guatemalan decorations, except that green is rare (Sampeck 2007). Verhagen (1997) gives a date for the production of Panama Polychrome A: 1600-1650.

Mexican majolicas (production beginning around 1550) include Puebla Blue on White, Mexico City Fine Grade, San Luis Mexico City Fine Grade, and Indigena ware (Verhagen 1997). The pastes of Puebla Blue on White and San Luis Mexico City Fine Grade are light-colored (white, tan, peach, or cream) (www.flmnh.ufl.edu/histarch; Sampeck 2007; Verhagen 1997), while the pastes of Mexico City Fine Grade and Indigena ware are red (Lister and Lister 1982; Sampeck 2007; Verhagen 1997). Mexico City wares can be decorated with blue or green, or no decorations (Verhagen 1997). Indígena wares are either plain or decorated with sgraffito (Sampeck 2007).

The Spanish majolica types are Columbia Plain, Sevilla Blue on White, Sevilla Blue on Blue, and Sevilla White. The pastes are light, but they are fine and weather like the Panama majolicas (Sampeck 2007). Spanish majolicas started appearing at New World sites as early as 1493 (Deagan 1987; Verhagen 1997). 


\section{VESSEL FORMS}

Beyond ceramic type, sherds were also analyzed for vessel form. The forms found at the three locations in Caluco were: bowl, cup, taza, jicara, bottle, pitcher, jar, bacín, pocillo, lebrillo, albarelo, escudilla, hollow ware, plato, platter, flat ware, candelero, lid, sack vessel, molcajete, comal, olla, open form, closed form, other, and unidentified form.

Tazas, jicaras, pocillos, lebrillos, platos, and escudillas are grouped together with bowls, cups, pitchers, hollow wares, flat wares, and platters under the heading of "serving vessels." A taza was a cup or small bowl that had a sharp angle and a wide mouth (Lister and Lister 1976). Both jicaras and pocillos were cups used to drink chocolate, with the jicara form based on gourds previously used for the same purpose, while the pocillo was very thin with ringed feet (Lister and Lister 1976). A lebrillo was a basin used to wash hands at the table (Lister and Lister 1976). Escudillas, based on a "typical Muslim form," were large, lidded bowls that were either baptismal fonts or soup tureens (Lister and Lister 1976: 42). A plato was a plate, which represented a move away from communal to individual dishes (Lister and Lister 1976: 72).

For the purposes of data tables, different kinds of bowls were not separated: hemispherical bowls are grouped with straight-sided bowls as they had similar uses. Sometimes, a sherd was classified as being either a bowl or plato. As a bowl is a hollowware and a plato is a flatware, that sherd was then classified as an open form.

Closed forms refer to the sherds that were classified as being a cup or albarelo, escudilla or albarelo, jar or bottle, or straight neck or albarelo, as these forms had 
narrower openings as other forms and were not decorated on the interior. The designation of unidentified forms is self-explanatory; but for classification of "other," in this case, refers to a porcelain artifact that is either a lid or figurine. In the tables shown in Chapter IV, bowls, cups, tazas, jicaras, bottles, pitchers, bacíns, pocillos, lebrillos, albarelos, and escudillas are all grouped together along with generic hollowwares as they are all hollowwares. The same is true for platos, platters, and flatwares.

I used three other classifications in my analysis: storage vessels, food preparation vessels, and other. Several vessels were classified as "storage vessels." These include lids, jars, bottles, and albarelos, which were drug jars (Lister and Lister 1976). Four types of vessels were "food preparation vessels:" sack vessels, molcajetes, comals, and ollas. Both comals and ollas were cooking pots, as Verhagen (1997) noted many had evidence of burning on their bases. Molcajetes were bowls used for grinding, with grooves on the interior (Verhagen 1997). "Other vessels" included candeleros (candleholders), effigies, and bacínes (large, straight-sided chamber pots) (Lister and Lister 1976).

\section{DECORATIONS}

In addition to ware type and form, I analyzed the sherds for any type of decoration. For the earthenwares, this usually means the application of a red slip, but there were also some geometric designs and pie crust rims identified in the assemblages. For the majolicas, decorations were recorded as: Italianate (yellow, green, black, brown, and blue, with the blue only being on Guatemalan majolicas); Oriental (blue and white); plain (no decoration), purple, and sgraffito (when the decoration is cut into a slip). Pie 
crust (wavy) rims were also considered for both the majolicas and indigenous earthenwares.

Adams (1989) and Graham (1998) state that the Spanish encouraged Spanish decorations to be produced on locally-made pottery. However, others have found that the Spanish were not thrilled with the adoption of their methods and decorations, as they saw it as thievery and a way for natives to get ahold of the market (Rodriguez-Alegría 2003; Sampeck 2015). Some of these decorations included flowers, the Maltese cross, eightpointed stars (Adams 1989), and the application of wash-like slips (Graham 1998).

\section{SUMMARY}

The analysis of ware, form, and decoration can help determine resistance. Analyzing all three factors can show what was popular where (especially in regard to local ceramics when European ceramics were plentiful and inexpensive), and similarities to other areas of turmoil where earlier styles of pottery were still preferred can indicate resistance.

As will be shown in the following two chapters, serving vessels are the most common forms over all, but traditional forms are more common at the church, while Spanish forms are more common at either house. The trend is similar for ware type and decoration: native at San Pedro y San Pablo, and introduced at the houses. This appears to be resistance as the Pipil were forced to live and work at the church and could have been retaining their traditional ceramics as a means of resisting their situation. 


\section{CHAPTER IV}

\section{ANALYSIS OF MATERIALS}

To determine if resistance was practiced in Caluco, I examined vessel form, ceramic ware, and decoration from San Pedro y San Pablo and houses Q and R. In this study, I analyzed a total of 1456 sherds (1384 vessels). Also, I used data from Caluco analyzed elsewhere (Sampeck 2015; Verhagen 1997), which provided 289 more sherds (22 more vessels). Vessels were analyzed for form (serving, preparation, or storage), ware (indigenous earthenware or European wares), and decoration (plain, red slipped, or pie crust rim).

\section{FORMS}

Serving vessels (flatwares, platos, platters, hollowwares, hemispherical bowls, straight-sided bowls, other bowls, cups, tazas, jicaras, pitchers, pocillos, lebrillos, and escudillas) were the most common in Caluco in general. For storage vessels (albarelos, lids, jars, and bottles), there were more jars than other forms, which made storage vessels more common than food preparation vessels (sack vessels, molcajetes, comals, and ollas), otherwise, the two categories were evenly distributed, with a greater variety of food preparation vessels. For forms that do not fit into the categories of serving, storage, or preparation vessels, three candeleros, three bacínes, and one effigy were present. 
Unidentified forms were not included in Figure 2. Altogether, the analysis identified 316 such vessels.

Figure 2. Total Identified Forms for all Types and Sites.

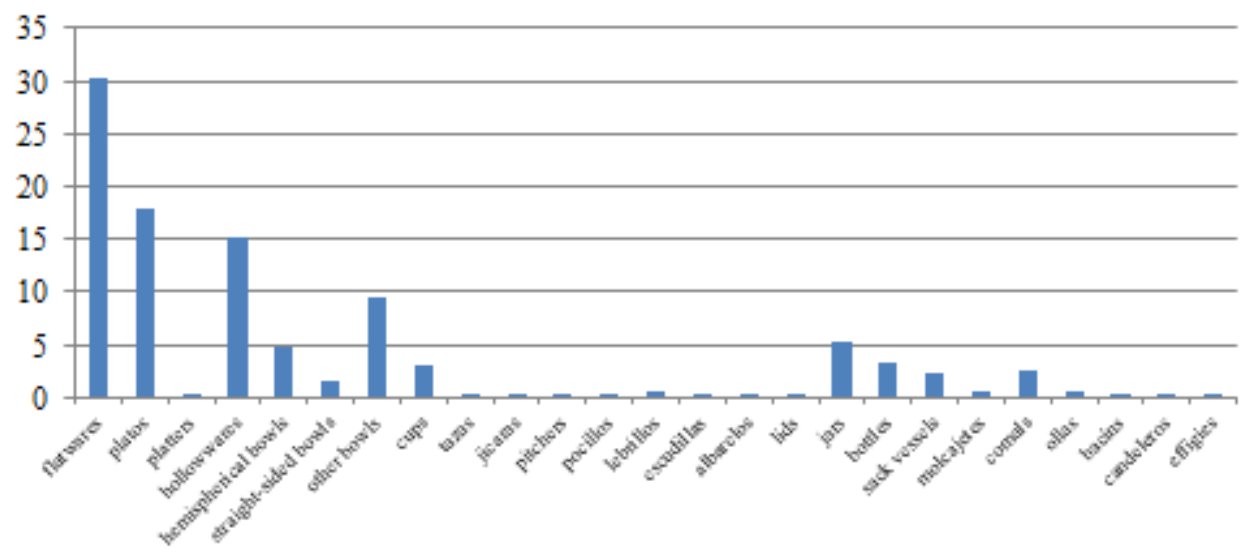

Several forms were present in all three locations: flatwares, platos, platters, hollowwares, bowls, cups, jars, and bottles (serving and storage vessels, but not food preparation vessels). Escudillas were present at either house, but not San Pedro y San Pablo. Bacínes and lebrillos were found at the church and House Q, but not House R, while all hemispherical bowls came from the church and House R.

San Pedro y San Pablo (Figure 3) had all of the straight-sided bowls (offertory plates, which were a pre-Columbian vessel form) and almost all of the hemispherical bowls. More serving vessels were present than at the other two locations, as well as more of a variety in food preparation vessels (all of the sack vessels, comals, and ollas). In addition, the only effigy (bird) from the whole assemblage came from San Pedro y San Pablo. 
Figure 3. Forms Present at San Pedro y San Pablo.

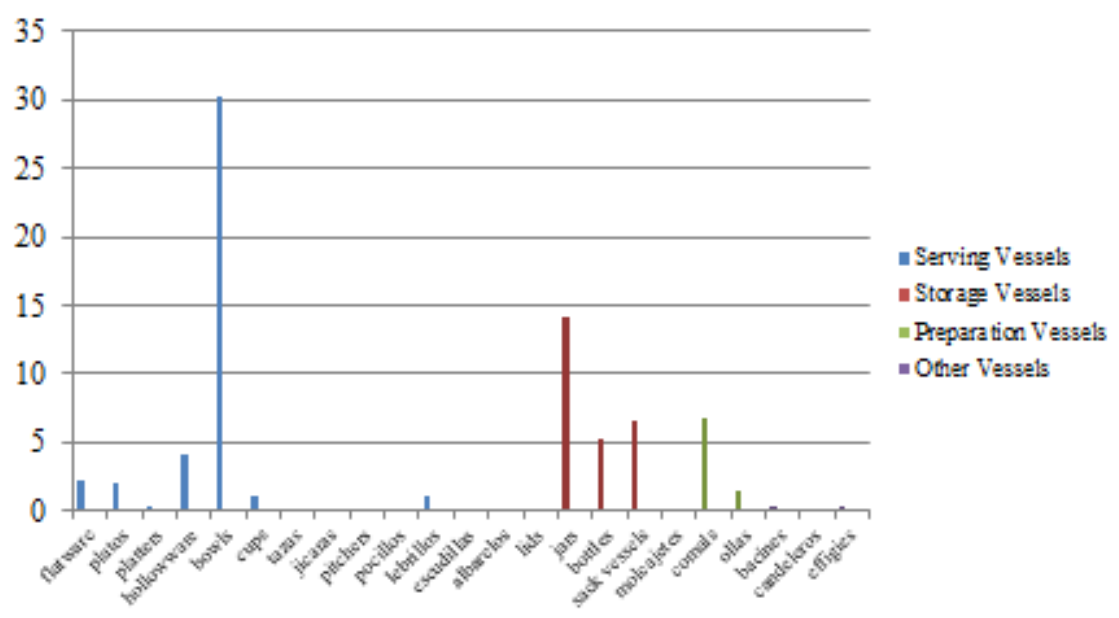

House Q (Figure 4) had the higher percentage of serving vessels and a lot more variety of forms in general, including several forms not found at the other two locations (tazas, jicaras, pitchers, and pocillos). All of the molcajetes and candeleros came from House Q, as well as many more bacínes. House R (Figure 5), meanwhile, had more serving vessels than food preparation or storage vessels. These results imply that the serving/eating of food was the most common activity at all three locales, while San Pedro y San Pablo had the greatest variety of activities, which would correspond with the numerous different activities that take place in church services. 
Figure 4. Forms Present at House Q.

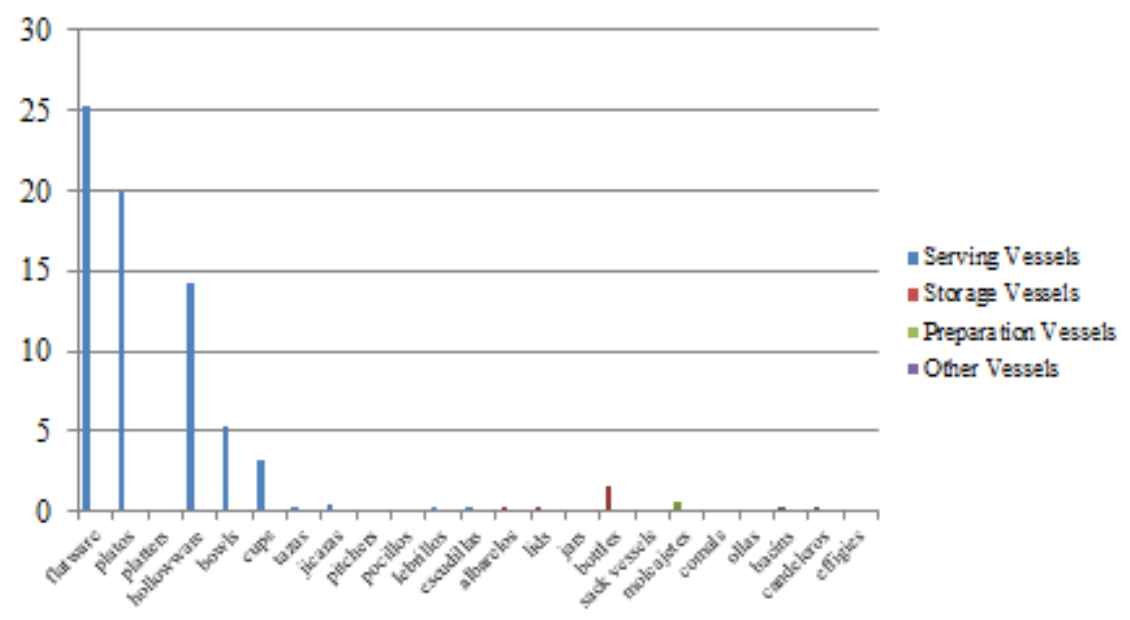

Figure 5. Forms Present at House R.

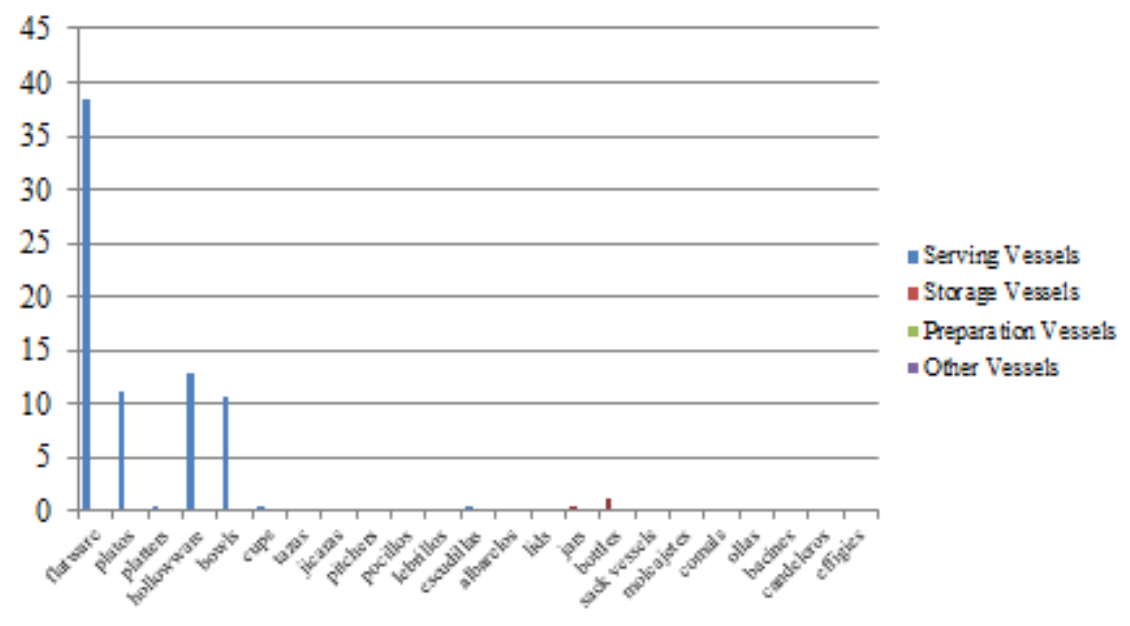




\section{TYPES}

Sixteen types of the ceramics (Figure 6) found at the three locations are earthenwares (Dario, Pantaleón Brown, Teofilo, Raimundo, Pantaleón Plain, Camilo, Telesforo Plain, Olive jar, Catalina, Apolonio, lead-glazed redware, lead-glazed earthenware, green lead-glazed, Spanish lead-glazed, Melado, and Teshcal). Pantaleón Plain is the most common earthenware type found in Caluco, followed by Dario. There were also several Teofilo and olive jar vessels, but none of the rest of the types numbered more than nine.

Figure 6. Total Identified Earthenware Types for all Sites.

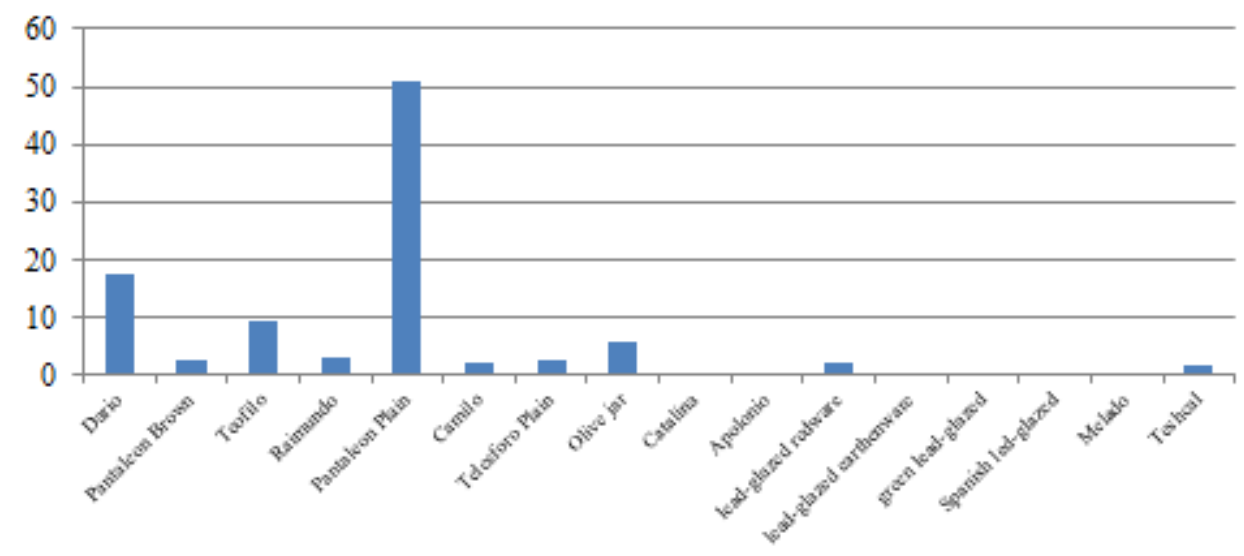

The church (Figure 7) had the majority of earthenware vessels, especially the unglazed types. House Q dominated with some of the lead-glazed earthenwares; while House R only had the most lead-glazed redwares. House R only had three out of 16 types (lead-glazed redware, lead-glazed earthenware, and Teshcal). The only earthenwares that House Q had that were not lead-glazed were one Teofilo vessel and five Teshcal molcajetes. The distribution of these wares is quite dramatic, and it should be noted that 
nearly all the earthenwares were from San Pedro y San Pablo, which was heavily manned with indigenous residents. This is significant in my argument regarding resistance in its similarities to American slave-made colonoware, which will be discussed in the next chapter.

Figure 7. Earthenware Types Compared by Sites.

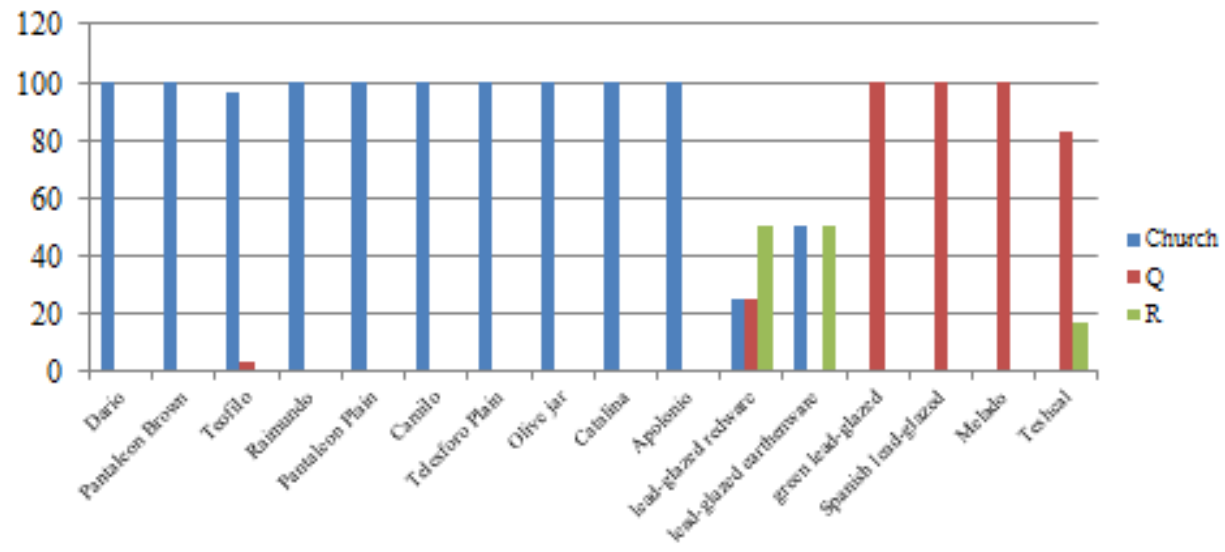

For glazed wares at the three locations (Figure 8), sherds were compared instead of vessels because it was not known how many vessels were represented from the church. For the three locations, Guatemalan majolicas were the most common. There were also quite a few Columbia Plain and whiteware sherds. Panamanian majolicas were more common than Spanish or Mexican majolicas. 
Figure 8. Total Glazed Ware Types for all Sites.

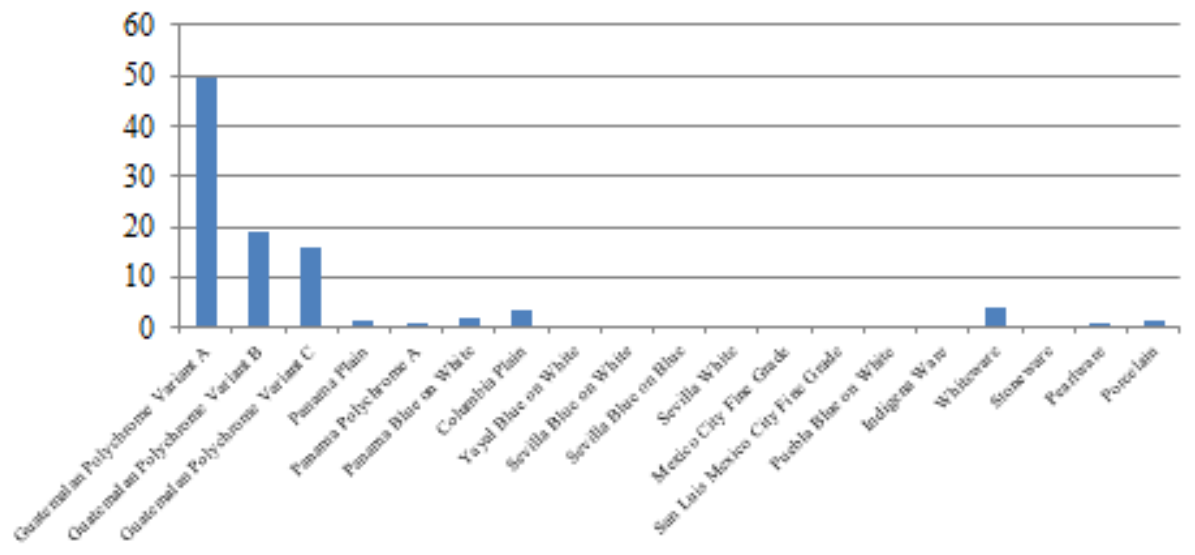

House Q (Figure 10) either had the majority of majolicas for each type, or tied House R (Figure 11) for a few (Sevilla Blue on Blue, Sevilla White, and Indigena ware). The church (Figure 9) had more refined glazed wares than either house, except for porcelain, which was more present in House Q. The only Yayal Blue on White or stoneware sherds came from the church, while the only San Luis Mexico City Fine Grade and Puebla Blue on White sherds came from House Q. For only two types of majolicas did the church have more than the houses (Panama Plain and Panama Blue on White). While all three locales each had more Guatemalan Variant majolicas than the other types, the two houses had considerably more majolica vessels than San Pedro y San Pablo, which relates to who occupied the church verses the houses and the reasons why the people who lived at the church would be less willing to use widely-available Europeanstyle ceramics (see discussion chapter). 
Figure 9. Glazed Ware Types Present at San Pedro y San Pablo.

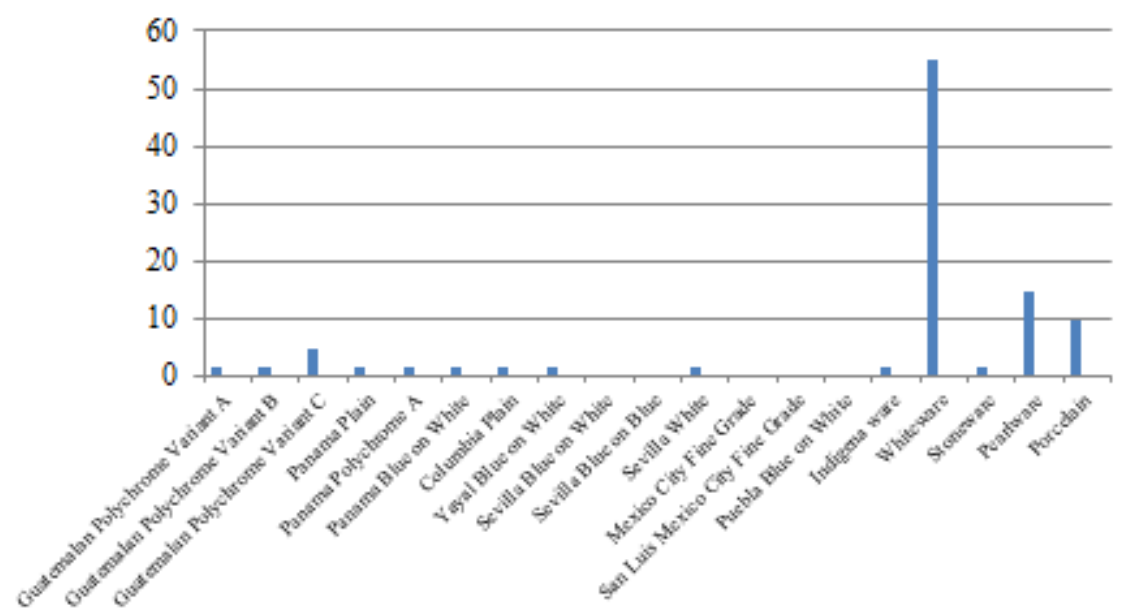

Figure 10. Glazed Ware Types Present at House Q.

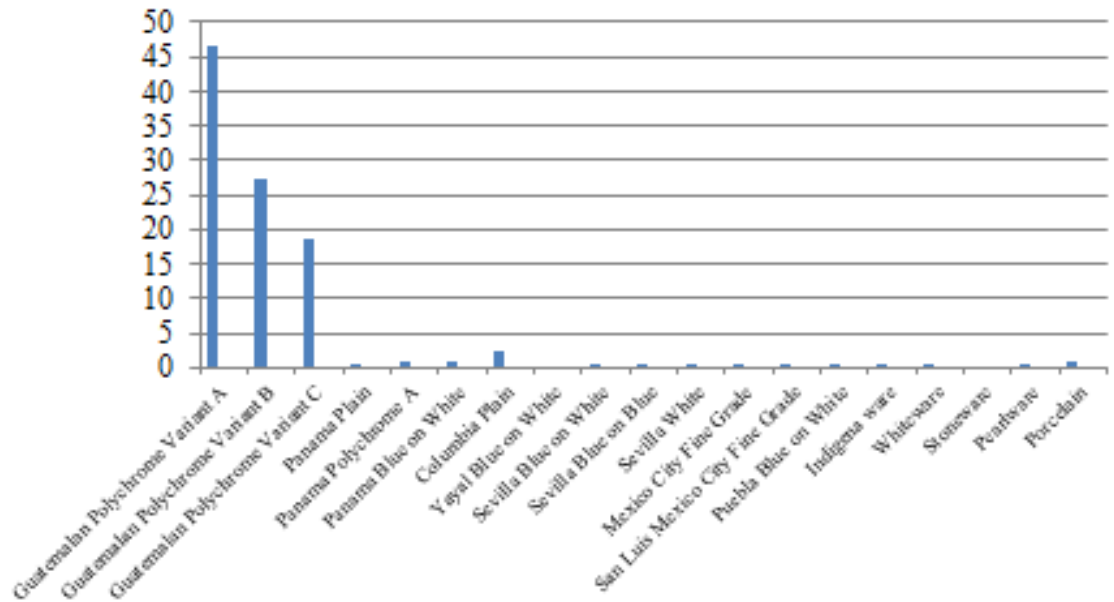


Figure 11. Glazed Ware Types Present at House R.

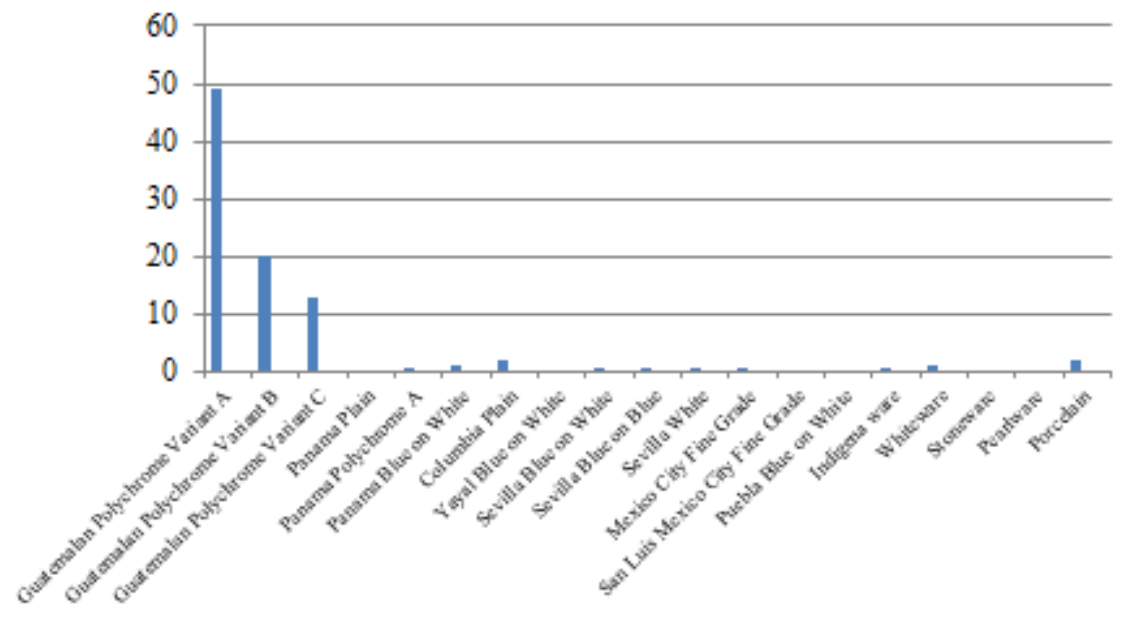

\section{DECORATIONS}

For Caluco in general (Figure 12), Italianate designs were the most common decoration. Plain vessels were the second most common, followed by red slip, Oriental, and pie crust rims. There were very small percentages of sgraffito, purple, red, transfer print, hand-painted, stencil, annular, molded, or decal designs.

Figure 12. Total Decorations for all Types and Sites.

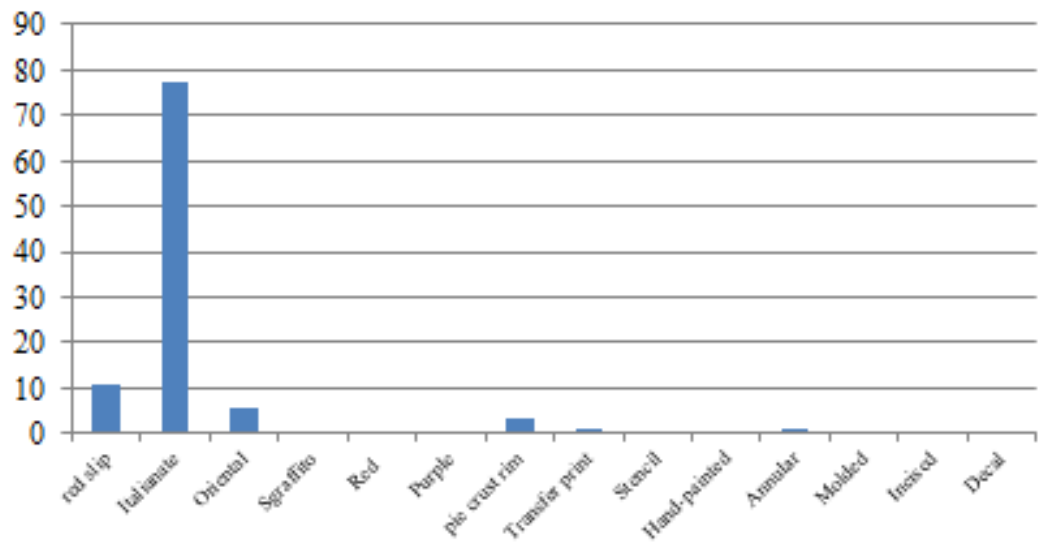


There was more variety in decorations from the Church, followed by House R, and then House Q (Figure 13). House Q had more Italianate and Oriental decorations than the other two locations. The church had all the red slipped vessels. House R had the only vessels with sgraffito, red, and purple decorations. Decoration is important to note because it could indicate that the people of the church stuck to traditional methods as a form of resistance, much the way that African American slaves continued the production of colonoware vessels in the American Southeast, which will be discussed in the next chapter.

Figure 13. Decorations Compared by the Three Locations. All percentages are based on sherds, except for all 233 of the Italianate designs from the church.

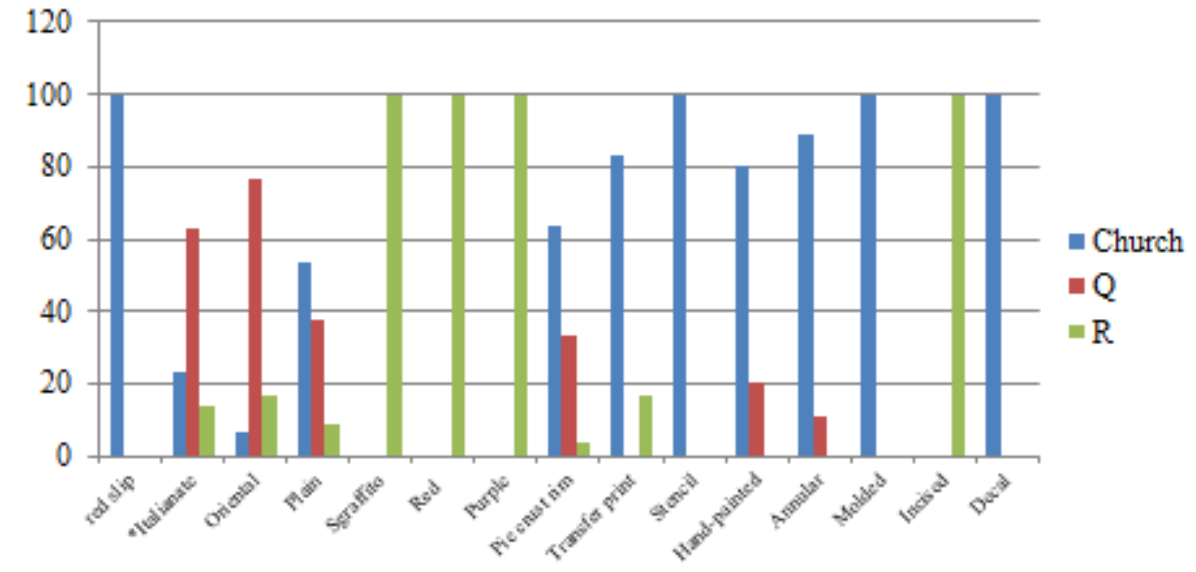

\section{PIE CRUST RIMS}

The presence of pie crust rims is important to note because they were a Spanish form that was adopted by native potters. Pie crust rims appear only on serving vessels at Caluco (Figures 14 and 15), and on eight out of 14 fourteen forms (hemispherical bowls, straight-sided bowls, platos, general bowls, cups, lebrillos, hollowwares, and flatwares). The majority of each form from the three locations did not have pie crust rims; the only 
exception was two out of three majolica lebrillos from House Q. Nineteen total vessels from the church had pie crust rims (on three types_-Dario, Pantaleón Plain, and Teofilo), ten from House Q, and one from House R. Compared to other towns in the area, Caluco had the most pie crust rims on majolicas than the other towns (4), with three from the hinterland (Sampeck 2015). For the coarse earthenwares, Nahulingo had twelve (two more than Caluco), while the hinterland had two (Sampeck 2015). Tacuscalco had no rims at all (Sampeck 2015).

Figure 14. Percentages of Vessels with Pie Crust Rims to Total Vessels from all Three Locations.

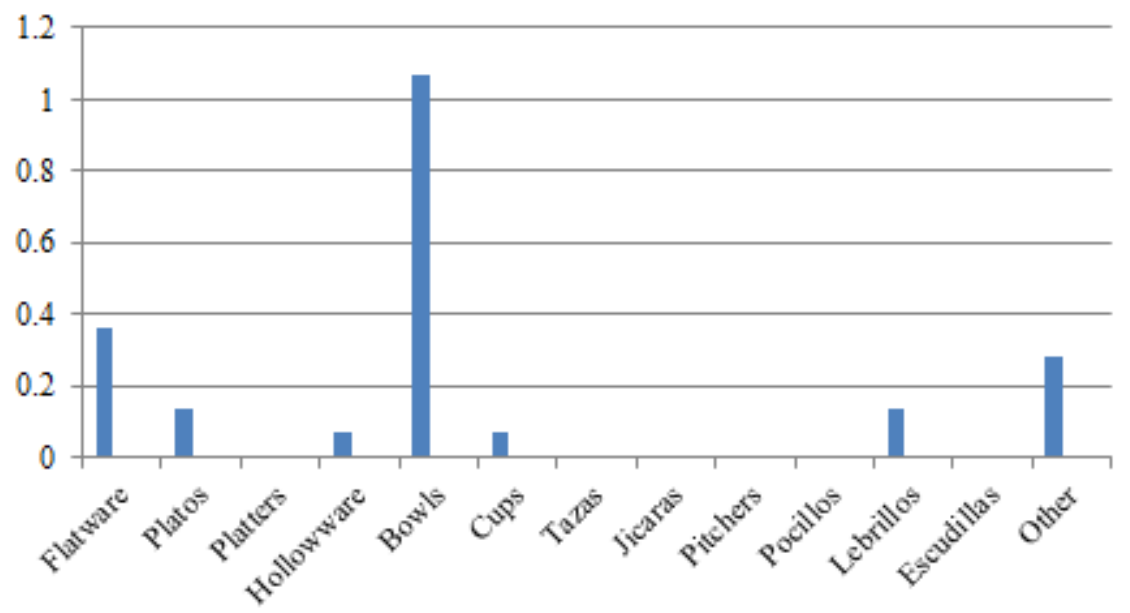


Figure 15. Percentages of Vessels without Pie Crust Rims to Total Vessels from all Three Locations.

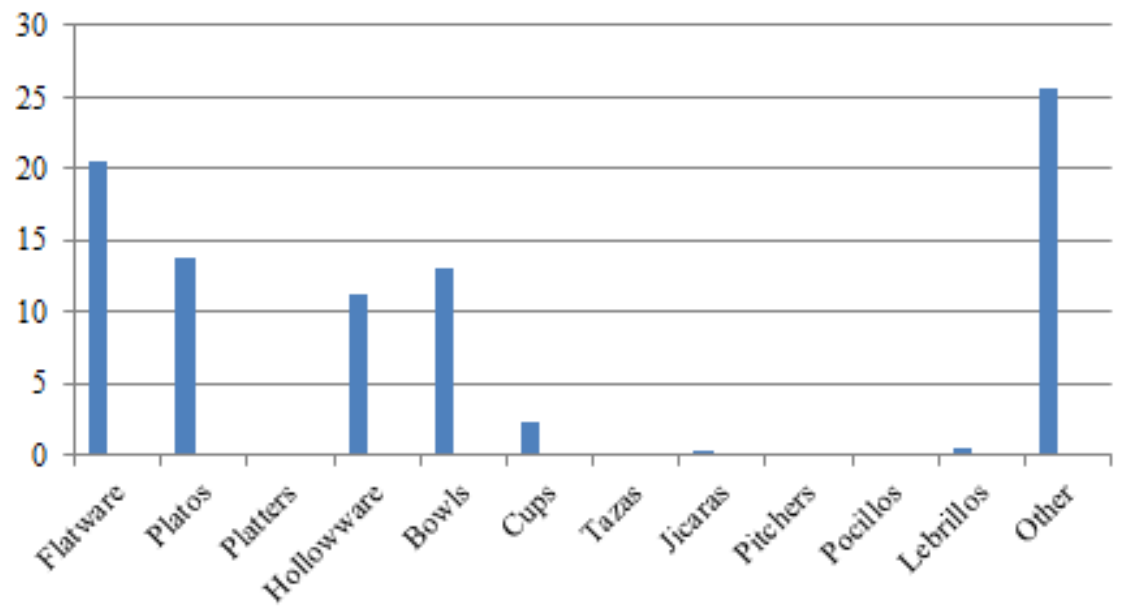

In the next chapter, the interpretation of these materials will be discussed. The ceramic frequencies of form, ware, and decoration can indicate resistance by showing where each of these items were present and who was using them, all while being interpreted against similar examples in other locations. While the three locales had some some overlap, there were quite dramatic differences as well. The residents of San Pedro y San Pablo continued the use of locally-made, undecorated earthenware, some styles of which dated from before the conquest, while the occupants of either house embraced European-style ceramics. The majority of my interpretation will compare these Indian earthenwares to African slave-made colonoware, which were present in the United States.

Colonoware vessels found in the United States are low-fired pots made of local clays (Matthews 2010). Originally these pots (then called colono-Indian ware) were assumed to have been made by Native Americans for trade (Noel-Hume 1962), but starting in the 1970s, archaeologists have come to realize that they more likely were of African American slave manufacture (Lees and Lees 1979; Matthews 2010). Ferguson 
(1980) was a big proponent of this, but he suggested renaming the vessels colonoware to indicate both Native American and African American manufacture (Matthews 2010). Since Ferguson's work, thousands of colonoware sherds have been found on slave quarters at plantation sites in the Chesapeake and Southeast (Matthews 2010). In this case, Matthews (2010:180) states that colonoware "could be considered a product of these groups' engagement with colonization," and many archaeologists use colonoware as an example of resistance of slaves (Agorsah 1993; Ferguson 1980, 1991; Matthews 2010; Orser and Funari 2001; Weik 1997).

I am not calling the materials from Caluco colonoware, but there are similarities between the two that lead me to believe that this is an appropriate comparison, which will be discussed in the following chapter. Even though this assemblage and colonoware were made by two different ethnicities, both were produced by marginalized groups suffering the harshness of colonialism. 


\section{CHAPTER V}

\section{DISCUSSION}

Artifacts do not just tell us what was present at a site in time. They can also tell us what time was like at the site in question. "The relationship of behavior to the material world is far from passive; artifacts are tangible incarnations of social relationships embodying the attitudes and behaviors of the past" (Beaudry et al. 1991: 150). Deetz $(1977: 35)$ states that it is these interactions that shape the world, and the material culture created these interactions.

The information in the preceding chapter will help answer the research questions in this chapter, stated again: 1) did the Pipil of Caluco, El Salvador, resist evangelization at San Pedro y San Pablo? 2) Can resistance be determined by comparing ceramics of the church to ceramics from privately-owned residences? 3) What are the characteristics of the ceramics in the area of the church in Caluco? 4) How do ceramic ware, form, and decoration indicate conformity or resistance? 5) How do church area ceramics compare to private, domestic contexts in Caluco?

Why would the Pipil of Caluco even resist evangelization/missionization? Lockhart (1992:203) states that in preconquest Mesoamerica, when an area was conquered, the god of the conqueror was incorporated into existing religions. The Pipil only needed to be instructed and not converted (Lockhart 1992:203). However, the Pipil 
of Caluco experienced an extreme form of congregación (Sampeck 2015), and the practice of resisting Catholicism could have maintained "beliefs that secured their identities despite the dehumanization, oppression, and violence of enslavement and racism" (Matthews 2010:182), much as African Americans navigated slavery in the American South. The extreme violence against the Nahua of Mexico City at the hands of the Spanish caused the Nahua to better understand their native religion and use that knowledge to resist the Spanish (Stear 2014), which the Pipil of Caluco could have done as well.

This chapter will discuss different lines of evidence that indicate that the Pipil of Caluco were resisting, if not evangelization or missionization, the harsh conditions of colonial life. Both the types of ceramics and the different forms these took are compared to African-American ceramics from the southeastern United States. In addition, the decorations present on the San Pedro y San Pablo pottery indicate resistance, as well. Finally, the ceramics of the church are compared to the assemblages of two houses in Caluco.

\section{FORMS PRESENT IN CALUCO}

This discussion needs to start with listing what vessel forms were traditional versus what forms were European imports (see the Methodology chapter for a discussion of the function of each form). The traditional (older) forms were the sack vessels, molcajetes, comales, ollas, effigies, some bowls, bottles, and jicaras (Lister and Lister 1976; Verhagen 1997). The European, and thus newer, forms were the platos, tazas, 
pocillos, lebrillos, escudillas, albarelos, candeleros, (olive) jars, some bowls, and bacínes (Lister and Lister 1976).

Forms Present at San Pedro y San Pablo

There were not many church-related artifacts found at San Pedro y San Pablo. Only eight platos were there (these have all been classified as "serving vessels," but some could have been offertory plates). Nine flat ware vessels were present at the church, and some of these could have been platos used as offertory plates as well. None of the three candeleros or three escudillas (possible baptismal fonts) from Caluco were found at San Pedro y San Pablo.

So what was present at San Pedro y San Pablo? Like Caluco in general, serving vessels were more common. However, bowls are more common than flat wares (the reverse of what is present in the town in general). For storage vessels, there were more jars and bottles found at the church than either house, along with all of the sack vessels (26) of the entire assemblage. All 6 ollas and 27 comales (food preparation vessels) were found at San Pedro y San Pablo.

San Pedro y San Pablo had a greater number of traditional forms than European forms. There were 21 bottles, 26 sack vessels, 6 ollas, 27 comales, and one effigy for a total of 81 traditional forms. Out of the other 302 vessels, 233 are not being used in this part of the discussion because they could not be identified specifically enough for this section (bowls, flat wares, hollow wares, "open” forms, "closed” forms, and unidentified). That leaves 69 vessels of known European forms found at San Pedro y San Pablo (56 jars, including 19 olive jars; 1 bacín; 4 lebrillos; and 8 platos). San Pedro y 
San Pablo's assemblage is quite different from the rest of Caluco, which will be discussed below.

\section{Forms Present at House Q}

House Q and San Pedro y San Pablo were tied for the greater variety of forms (14). Nine of those forms were serving vessels (in decreasing order of prevalence: flat wares, platos, hollow wares, bowls, cups, jicaras, and then equal numbers of tazas, lebrillos, and escudillas). There were three types of storage vessels: albarelos, lids, and bottles. The only food preparation vessels were five molcajetes, and for "other vessels," there were two bacínes and three candeleros. This is similar to other domestic Spanish sites, such as in Saint Augustine (Deagan 1978) and the Caribbean (Deagan 1988).

There were more items related to church activities found at House Q than San Pedro y San Pablo. For instance, all three candeleros from the whole assemblage came from House Q, in addition to two of the escudillas. As the flat wares and platos could have been either offertory plates or serving vessels, it is important to note that House Q had 208 flat wares and 164 platos.

House Q had more newer European forms than older traditional forms. Out of 822 total vessels from House Q, 181 forms were European (three tazas, one jar, two bacínes, one pocillo, three lebrillos, two albarelos, two escudillas, 164 platos, and three candeleros). Only 22 vessels were of traditional forms (four jicaras, 13 bottles, and five molcajetes). The other 619 vessels were left out of this section for the same reason as stated above in the discussion of San Pedro y San Pablo. 


\section{Forms Present at House $R$}

House $\mathrm{R}$ also had a lot more serving vessels than any other kind. Flat wares were the most common with 72 vessels, followed by 24 hollow wares, 21 platos, 20 bowls, and one cup, platter, and escudilla apiece. There were only two kinds of storage vessels present (one jar and two bottles), and zero food preparation or "other vessels."

The two bottles are the only artifacts present that could be considered traditional, and only 23 artifacts (the jar, escudilla, and platos) were European. This is similar to research of other Spanish colonial sites in that storage or preparation vessels that were typically not for public use were Indian, while serving (public) vessels were European (Deagan 1988). Of the total 187 artifacts from House Q, 162 had to be ignored for this section because form could not be determined.

\section{WARE TYPES PRESENT IN CALUCO}

The types of earthenwares present at the three locations in Caluco are (in chronological order from Postclassic to nineteenth century): Catalina, Pantaleón Plain, Pantaleón Brown, Teofilo, Raimundo, Dario, Apolonio, Telesforo Plain, Teshcal, Camilo, lead-glazed earthenwares, and olive jar (descriptions of these can be found in the Methodology chapter). Of these ware types, everything except the lead-glazed earthenwares and olive jars are traditional wares.

Earthenware Types in Caluco

San Pedro y San Pablo had greater variety of Indian-made earthenwares with Dario, Pantaleón Brown, Pantaleón Plain, Raimundo, Camilo, Telesforo Plain, Catalina, 
and Apolonio vessels all present. It had none of the Teshcal vessels, and split with both houses on the lead-glazed earthenwares. A greater variety of Indian earthenwares was expected as the church's population was Indian.

Of the materials from House Q that I analyzed, there were six vessels of traditional ware types: one Teofilo vessel of an unidentified form and five Teshcal molcajetes. The vessels in Verhagen (1997) also include Pantaleón, Telesforo, Raimundo, Dario, Teofilo, and Apolonio, as well as Gines and Alejo, which were not present at San Pedro y San Pablo. The European wares at House Q were four lead-glazed earthenwares, three of which had unidentified forms, and the fourth was a pitcher.

From my analysis, House R had none of the traditional ware types except for one Teshcal vessel with an unidentified form. However, according to Verhagen (1997), there were also vessels of Pantaleón, Telesforo, Raimundo, Dario, Teofilo, and Apolonio. For the European ware types, House R had five lead-glazed earthenwares (three with unidentified forms, one hollow ware, and one escudilla). The presence of Indian-made earthenwares at two Spanish house sites was expected as the Spanish were more likely to adopt Indian materials than the Indians were to adopt Spanish materials (Deagan 1978).

\section{Majolicas in Caluco}

There were 15 type of majolicas present in Caluco: Guatemalan Variants A, B, and C; Panama Plain; Panama Polychrome A; Panama Blue on White; Columbia Plain; Yayal Blue on White; Sevilla Blue on White; Sevilla Blue on Blue; Sevilla White; Mexico City Fine Grade; San Luis Mexico City Fine Grade; Puebla Blue on White; and Indigena Ware. The Guatemalan Variants (A, B, and then $\mathrm{C}$ ) were the most common, 
followed by Columbia Plain, the Panama variants, and then just a couple each of the other types.

This was not surprising as the majority of the majolica from Caluco came from either house. Nearly all of these vessels, except for the plain examples, were decorated with Italian designs. The blue decorations can be considered Italian, because even though they were Oriental in origin, Italian potters recreated the designs on their majolicas (Lister and Lister 1976). The Spanish were purchasing Italian-style majolicas in Spain well before potters in Spanish America began recreating the same designs for their customers (Lister and Lister 1976). At San Pedro y San Pablo, however, resistance is not as much noted in the variety of decorations of majolicas, but in the small amount of majolica vessels in general, which is outlined below but will be discussed in more detail later in this chapter.

\section{Majolicas at San Pedro y San Pablo}

San Pedro y San Pablo had two known majolica vessels (the other 283 were sherds to which I did not have access), and both were Guatemalan Variant C and unidentified forms. Of the sherds, 180 were Guatemalan Variant A, 20 were Guatemalan Variant B, 35 Guatemalan Variant C, nine Panama Plain, four Panama Polychrome A, 11 Panama Blue on White, four Columbia Plain, two Sevilla Blue on White, two Sevilla White, two Yayal Blue on White, and one Indigena ware. All of these have unidentified forms. A stronger statement regarding the relationship between majolica and resistance could have been achieved if I had been able to analyze these sherds myself. 


\section{Majolicas at House $Q$}

There were 796 majolica vessels at House Q. Guatemalan Variants A (376), B (220), and C (152) were the most common, followed by Columbia Plain (19), Panama Polychrome A (7), Panama Blue on White (6), Panama Plain (4), Puebla Blue on White (3), Sevilla Blue on White (3), Mexico City Fine Grade (2), and one each of Sevilla Blue on Blue, Sevilla White, San Luis, Mexico City Fine Grade, and Indigena Ware.

Of the 796 vessels, 181 had later, European forms. These include: three tazas, one jar, two bacínes, one pocillo, three lebrillos, two albarelos, two escudillas, three candeleros, and 164 platos. Only 17 were traditional forms: four jicaras and 13 bottles. Nearly 600 vessels had to be omitted for this part of the discussion because their forms could not be identified beyond hollow ware, flat ware, or unidentified.

\section{Majolicas at House $R$}

Like San Pedro y San Pablo and House Q, House R had more Guatemalan Variant $\mathrm{A}, \mathrm{B}$, and then $\mathrm{C}$ majolicas than any other type. The breakdown is Guatemalan Variant A (97), Guatemalan Variant B (40), Guatemalan Variant C (25), Columbia Plain (4), Panama Blue on White (2), and one each of Panama Polychrome A, Sevilla Blue on White, Sevilla Blue on Blue, Sevilla White, Mexico City Fine Grade, and Indigena Ware (fewer vessels, but a similar trend as House Q). Over 150 of the majolica sherds were too vague to use for this discussion, but there were two bottles (traditional form) and 21 platos (European form) present at House R.

Both houses had similar trends to other Spanish domestic sites. In Saint Augustine and the Caribbean, for example, the Spanish used their style pottery for 
serving vessels, or any kind of vessel that would have been seen by visitors to their homes (Deagan 1978, 1988). Ninety one percent of the majolica from either house were serving vessels (181 vessels out of 198 total majolicas from House Q, and 21 out of 23 for House R).

\section{DECORATIONS}

The vessels in my assemblage had a wide variety of decorations, but typically just at either of the houses. The crux of my argument is based on the materials present at San Pedro y San Pablo, where very little variety in decoration existed. While a breakdown of decoration follows, the most important point for my discussion involves the presence of undecorated earthenwares and pie crust rims, both of which will be discussed later in this chapter.

The majority of vessels had Italianate designs, followed by red slip, Oriental designs, and then pie crust rims. The Italianate and Oriental designs were exclusively on majolicas, while the red slips were exclusively on the traditional earthenwares. Pie crust rims were present on both indigenous and European vessels. All of the red slipped vessels came from the church, but the Italianate, Oriental, plain, and pie crust rim vessels were divided among the three locations. House Q had more Italianate and Oriental decorations than either of the other two locations, while San Pedro y San Pablo had more of the plain vessels and those with pie crust rims. House $\mathrm{R}$ had the only incised vessel of the whole assemblage, which was an Indigena Ware plato. Decorations on whiteware, stoneware, and porcelain are included in my figures in the analysis chapter, but as those 
wares are more recent, they will not be discussed in this thesis (these include transfer prints, stencils, hand-painted, annular ware, molded wares, and decals).

Pie crust rims are only present on serving vessels in my assemblage, and then only on (in decreasing order of percentage) bowls, flat ware, other vessels, platos, lebrillos, hollow wares, and cups. Vessels of these forms were more likely to not have pie crust rims, as can be seen in a comparison of Figures 14 and 15 in the analysis chapter. No vessel forms had only pie crust rims, and platters, tazas, jicaras, pitchers, pocillos, and escudillas had no pie crust rims.

\section{COLONOWARE COMPARISON}

Of interest in this section is the large number (over 300) of Indian-made earthenware vessels from San Pedro y San Pablo. While all the sherds were analyzed for specific types (which can be found listed in the methodology chapter), it is best for the following discussion to not separate them but keep them grouped together under the heading of "Indian-made earthenware." These vessels were found at the church with a few European-made pieces, and I believe their presence indicates resistance on the part of the indigenous laborers residing at the church. Examining how colonoware has been used as resistance by African Americans in the U.S. can provide insight in how Indianmade pottery in Caluco could have been used in the same manner.

There are several similarities between colonoware from the United States and the Indian-made coarse earthenware found at San Pedro y San Pablo. First, the increasing presence of colonoware in the Chesapeake is tied to both an increase in the African population and distinctions by race (Matthews 2010). Even though the ceramics at San 
Pedro y San Pablo were produced by indigenous residents and not African slaves, the large number present when European ceramics were available could indicate a similar occurrence. Latin America as a whole was going through virtually the same thing, with lots of laws (repartimiento, encomienda, congregación, and reducción have already been discussed in the historical background chapter) being enacted that formalized these racial differences.

Another similarity in regard to colonoware is the organization of Virginia landscapes when compared to Caluco. Colonial Virginia had certain areas for whites (plantations, churches, courthouses, and other public structures) and certain areas for blacks (houses, work areas, fields, and forests) (Matthews 2010; Upton 1988, 1990). These places allowed the slaves to create a "sense of belonging" in a community in areas where whites had no influence (Matthews 2010). This is visible in the church in Caluco. San Pedro y San Pablo was maintained by indigenous laborers and it is reasonable to suggest that the people who worked here continued their ceramic traditions as a way to maintain their identity and a sense of belonging during the racial turmoil of the Spanish colonial period.

Colonoware was an active form of resistance utilized by slaves and had West African origins (Ferguson 1980, 1991). Matthews (2010) and Ferguson (1991) have already been discussed, but there are several other examples of colonoware being used as resistance. This can be seen in the maroon community of Palmares, Brazil, and Orser and Funari (2001) argue that colonoware helped create a sense of belonging even with outside influences. Other areas where colonoware was present and used as resistance include Jamaica, Dominican Republic, Brazil, Florida, and North Carolina (Weik 1997). 
Agorsah (1993) discusses the West African antecedents of colonoware had how it was then used as resistance in the Caribbean. Also, not just ceramics have been used to resist colonialism. In Xaltocan, Mexico, the Indians continued their stone tool production after the introduction of steel knives and even began producing chipped-stone tools again, which they had stopped well before the arrival of the Spanish (Rodríguez-Alegría 2008). Another example is Rancho Petaluma in California, where resistance is one of the possibilities that the Indians could still have been using lithics when Spanish substitutes were available (Silliman 2001).

The continual production of the earthenware vessels at the church in Caluco can be seen in a similar manner to colonoware. The vessels were produced during times of greater interaction and the landscape in which both types of ceramics were similar. Resistance was practiced and can be seen in that European-made wares in a variety of types were prevalent at the church, so the indigenous earthenwares were not necessarily needed. Matthews (2010) argues that Africans in the United States used colonoware production to make a statement that they were "unlike them" (whites), which is how I believe the Indians at Caluco were using their earthenwares. Also, both examples were of earlier traditions (colonoware from western Africa and some of the pottery from Caluco continued from before the colonial period), so this continuation could have been what gave both groups a sense of belonging and a way to band together during the tumultuous times experienced in both places. 


\section{Colonoware Forms Comparison}

Comparing the forms of the local earthenwares in Caluco to colonoware forms can show resistance, as well. Matthews (2010) found that in Virginia, colonoware and European wares displayed similar forms. He states that in the past, archaeologists have assumed that this merely means more interaction, but they did not take into account all the cultural processes coming into play, such as domination and resistance (Matthews 2010: 181). Instead, the slaves in Virginia were "asserting a position within society to challenge slavery and their exclusion" (Matthews 2010: 181).

Others have found differences between colonoware and European forms. At Brazilian and Jamaican maroon sites, colonoware was more commonly found in the form of cooking (giant cooking pots) and storage vessels (large tubs and different-sized water jugs) (Weik 1997). Likewise, sites in the Caribbean also revealed that colonoware was usually of large cooking or storage forms (Agorsah 1993).

Ferguson (1991) too found differences in colonoware forms when compared to European forms, and he focused more on the reason why these differences existed. Slaves in South Carolina ate the same way they did in West Africa, using similar vessels and cooking techniques (Ferguson 1991). Common forms found in both places included cooking jars and serving bowls (Ferguson 1991). Also, European-Americans preferred to use native- and African-made goods for some foods, such as okra (Ferguson 1991). Ferguson $(1991: 28,37)$ states that the use of traditional African forms was resistance against "European-American ideology" as the slaves were not "surrounded by an 
everyday symbolic environment that reinforced and explained their position in a hierarchy."

There were several parallels between the materials found at San Pedro y San Pablo and colonoware. Before the conquest, the most common serving vessels were large bowls, while the most common storage vessels were jars and the most common food preparation vessels were bacíns, ollas, sack vessels, and comals (Sampeck 2007). Forms introduced during the Colonial period include: albarelos (drug jars that were introduced in Spain by Muslims, escudillas (either wide, small bowls or large coffee cups), jicaras and pocillos (cups used to drink chocolate), lebrillos (large bowls used to wash hands at the table), and tazas (either cups or small bowls) (Lister and Lister 1976). At San Pedro y San Pablo, out of 241 earthenwares, 27\% (65 total) were of European forms. In contrast, $73 \%$ (176 total) retained traditional forms (forms categorized as hollowware, flatware, unidentified, open, closed, or other were not calculated for this section of the analysis). As stated above, Matthews (2010: 181) found that in Virginia, similar forms between colonoware and European wares meant not only greater interaction, but a "challenge to slavery and exclusion," which could account for the similarities found in Caluco.

While there were definitely some similarities in forms, resistance using foodways could account for the larger amount of differences. There were 45 earthenware vessels of European forms found at San Pedro y San Pablo (bowls, lebrillos, and platos). In contrast, there were 55 serving vessels of traditional forms and all of these were either hemispherical bowls or straight-sided bowls. So there was more variety of European forms, but traditional forms were still more common. For food preparation vessels, none 
were European, while the 60 earthenware vessels were of traditional forms (bacíns, sack vessels, ollas, and comals). For food storage vessels, the trend was the same: 20 (35\%) were European-form bottles, while 37 (65\%) were traditional jars. Food preparation vessels were more common in the Caribbean, South Carolina, Jamaica, and Brazil, but what is important to note is that at all these places and Caluco, all of these were traditional forms to the enslaved populations. This indicates resistance at the church in that the laborers there did not change their diet in response to Spanish demands, and instead resisted their positions in the hierarchy.

\section{Colonoware Decoration Comparison}

A comparison to colonoware can also be used regarding decorations. The vast majority of African-American colonoware is undecorated (Ferguson 1991). Ferguson (1991: 32) suggests that this is because homogeneity of the vessels "emphasized the similarities of slaves and reinforced their common heritage and their differences from whites."

While $102(32 \%)$ of the earthenware vessels at the church were decorated with red slips, $68 \%$ (218) of the vessels were not decorated at all. This could indicate that the Indians had a similar mindset as the slaves in South Carolina in that they believed similarity in pots symbolized their common heritage. As for the vessels with red slips, the makers of these could just have been carrying on earlier traditions, as some preColumbian pottery in the region displayed red slips (Verhagen 1997). What is interesting about the red-slipped examples from Caluco is that while almost all were on traditional forms, a lebrillo and brimmed plato also were decorated with slips. 


\section{Majolica}

I have used the small number of majolica from San Pedro y San Pablo to prove that the Pipil who occupied the church were picking Indian wares over this inexpensive commodity. It is also possible that they were using the majolica vessels they did have as resistance as well. In Xaltocan, Mexico, it was determined that commoners were using majolica to "subvert structures of power..." (Rodríguez-Alegría 2010: 51). Instead of adopting vessels of everyday use, the commoners of Xaltocan took showy Spanish serving vessels that they used in "feasts of empowerment" (Rodríguez-Alegría 2010: 65). The Pipil of San Pedro y San Pablo could have used their majolica in a similar manner, although this would be a stronger argument if I had been able to analyze the majolica from the church myself.

\section{Pie Crust Rims}

A final look at resistance involves the 18 earthenware vessels with pie crust rims from the church. At first glance, the presence of pie crust rims on Indian-made ceramics would indicate that the Indians at the church were not resisting, as pie crust rims are a marker of Spanish influence (Sampeck 2007). However, the Spanish were not pleased that Indians adopted this trait, as they saw it as theft by the Indians of their ideas (Rodríguez-Alegría et al. 2003; Sampeck 2015).

\section{TWO HOUSES}

The majority of the above discussion has dealt with what was present at the church, but what can be said about houses Q and R of Caluco? As I had access to very few of the indigenous ceramics from either house, only general assumptions can be made 
here. As stated in the historical background chapter, the homeowners were encomenderos who employed the Pipil as laborers in cacao production (Verhagen 1997).

Of interest in this section is a comparison of the majolica found at the two houses compared to the church. At San Pedro y San Pablo, 285 sherds were located, compared to 796 vessels from House Q and 194 vessels from House R. Archaeologists have tended to call majolica high status items, but Voss (2012) states that majolica was among the cheapest wares available. Her research focused on invoices of ceramics from two presidios in Alta California and found that form of the vessel was more important than type or decoration and that the majolicas were actually some of the cheapest ceramics acquired (Voss 2012). This research contradicted the notions that 1) "ceramics imported from Europe and China are more expensive" and 2) "majolica ceramics are the higheststatus ware of any ceramics produced in Spanish America" (Voss 2012). However, Voss (2012) was dealing with an eighteenth-century site in California, so there is the possibility that majolica meant and was worth something different there than in sixteenthcentury El Salvador.

Following Voss's (2012) statement that form was more important than ware type or decoration, resistance regarding majolica can be noted at the church when compared to the majolica from either house. At houses $\mathrm{Q}$ and $\mathrm{R}$, when form was able to be identified for each majolica, it was nearly always a Spanish form (cup, jicara, pocillo, lebrillo, albarelo, escudilla, plato, various types of bowls, bottle, candelero, and lid). Only four majolica vessels out of 970 had an indigenous form (one hemispherical bowl, 1 jar, and 2 bacíns). However, $68 \%$ of the total majolica vessels from either house could only be classified as hollowware, flatware, open forms, closed forms, or unidentified, which 
could impact this analysis. Of course, this statement could be stronger if I had been able to analyze the majolicas from the church, but based on the trends of the other ceramics available, indigenous forms were still more important to the indigenous residents of the church than the Spanish encomenderos of the two houses.

All three locales had many Indian-made earthenwares: 16,059 grams at House R and 44,572 grams at House Q (Verhagen 1997). How does the presence of earthenwares at San Pedro y San Pablo indicate resistance when these types were present at Spanish domestic sites in Caluco as well? The Spanish had no qualms about adopting Indian materials, especially those relating to storage and preparation, as seen in Spanish domestic contexts in Saint Augustine and the Caribbean (Deagan 1978, 1988). However, the assemblage at San Pedro y San Pablo is dominated by these types of vessels when European wares were readily available.

\section{CANDELEROS}

Three candelero sherds were recovered in Caluco. What is interesting is that none were from the church. All three vessels were Guatemalan Polychrome Variant A majolicas from House Q. Candles were an important aspect of Catholic services, first introduced to the Pipil specifically for worship, and are "clear evidence of Spanish influence" (Verhagen 1997:385), so it would be expected to find candeleros at a church.

\section{SUMMARY}

Regarding my first two research questions (Did the Pipil of Caluco resist evangelization at San Pedro y San Pablo? Can resistance be determined by comparing ceramics of the church to ceramics from privately-owned residences?), my analysis 
indicates that the answer to both of these questions is yes. For the third question (What are the characteristics of the ceramics in the area of the church in Caluco?), the ceramics of San Pedro y San Pablo consisted mainly of many Indian-made earthenware vessels with a variety of forms, some majolica (although it is not known what forms these took), some red-slipped local earthenwares, and a few pie crust rims.

For question number four (How do ceramic ware, form, and decoration indicate conformity or resistance?), resistance was evident in all these characteristics when comparing the assemblage to colonoware from the United States: local earthenwares in traditional forms with traditional or no decorations were more common than anything the Spanish introduced. A number of the vessels from the church displayed Spanish pie crust rims; however, the Spanish did not condone this taking of their stylistic ideas.

The first four questions can be answered easily, while the fifth question is a bit harder to answer (How do church area ceramics compare to private, domestic contexts in Caluco?). While the Church is comprised mostly of Indian earthenwares and little majolica, the houses had more of an even mix. The difficulty in answering this question results from not being able to analyze for myself the majolica from San Pedro y San Pablo or most of the earthenwares from Houses Q and R. However, the materials to which I did have access present enough of a picture to realize something different was taking place in San Pedro y San Pablo than either house site. 


\section{CHAPTER VI}

\section{CONCLUSION}

This thesis research focused on evidence for resistance to evangelization of Pipil workers at San Pedro y San Pablo, a sixteenth-century colonial parish church in Caluco, El Salvador, by comparing the ceramics from the church to two houses, also located in Caluco. Ceramics were grouped together by vessels, and then analyzed by ware, form, and decoration.

There is evidence of resistance at Caluco: local wares were produced after the introduction of Spanish wares (similar to colonoware by African American slaves in the United States); there were a lot more Spanish-introduced forms at either of the two houses than at the church; no Spanish-influenced decorations were found at any of the vessels from San Pedro y San Pablo (except for pie crust rims, which does indicate resistance as the Spanish did not approve of their designs being copied).

I think that resistance to evangelization is hard to determine, as Lockhart (1992) notes that Indians in Latin America readily accepted their conquerors religion whenever they were overtaken. However, I believe that the Pipil at San Pedro y San Pablo were resisting both the harsh conditions of Spanish colonization and evangelization. Life in sixteenth-century Caluco was harder than life in other areas of Latin America during the 
same time because of the cacao trade (Sampeck 2015). Resisting Catholic evangelization could have been the force that unified the Pipil.

For the Caluco materials, 1394 vessels were analyzed. A wide variety of indigenous earthenwares were present, nearly all from San Pedro y San Pablo. For majolicas, however, the majority of the vessels came from either House Q or House R. Some majolica was found at the church, but a small number when compared to the other two locales (794 majolica vessels from House Q, versus 283 majolica sherds from San Pedro y San Pablo). This indicates resistance in that the indigenous Pipil who inhabited the church were mainly choosing it over European-style ceramics, which were inexpensive and made available to them. My conclusion regarding majolica could have been improved if I had been able to analyze the majolica sherds from San Pedro y San Pablo for vessel count myself, instead of merely relying on sherd counts.

Another issue that needs to be resolved is that there was a large amount of indigenous earthenwares recovered at both houses, which could refute my statements likening the church wares to colonoware and resistance. However, I think resistance was still the case because the indigenous wares were the vast majority of the wares from San Pedro y San Pablo. Also, the Pipil were likely to be the cooks using the ceramics in the Spanish houses, so the indigenous materials found there could still be interpreted as resistance. Still, a way this analysis could have been improved would have been to examine these sherds myself for ware type, form, and decoration instead of merely relying on Verhagen's weights for these wares. At the very least, I should have weighed the indigenous wares from San Pedro y San Pablo for comparison to Houses Q and R. 
The Spanish introduced a large number of serving vessel forms to the area, of which very few were present at San Pedro y San Pablo, but nearly all were present at House Q (House R did not have a great number, but that could be because there were fewer ceramics total found at House R). San Pedro y San Pablo dominated in hemispherical and straight-sided bowls and preparation and storage vessels, none of which were Spanish introductions, and the majority of which were indigenous earthenwares in the style of pre-conquest vessels.

San Pedro y San Pablo's earthenwares continued to be red slipped; no typical Spanish decorations appeared on church ceramics except pie crust rims. At the outset, pie crust rims present on church materials did not appear to be evidence of resistance to me, until it was discovered that the Spanish were not thrilled when Indians adopted their decorations on indigenous earthenwares (Sampeck 2015).

The overall importance of this research was to determine if resistance to evangelization took place at San Pedro y San Pablo, an unexamined question in the vast amount of research already conducted with Caluco materials. It is my conclusion that the Pipil of the church did resist both evangelization and the harsh conditions of colonial life in sixteenth-century colonial life in Caluco, El Salvador. 


\section{REFERENCES}

Adams, Charles E. 1989. "Passive Resistance: Hopi Responses to Spanish Contact and Conquest." Pp. 77-91 in Columbian Consequences: Archaeological and Historical Perspectives on the Spanish Borderlands West. Vol. 1, edited by D.H. Thomas. Washington: Smithsonian Institution Press.

Agorsah, E. Kofi. 1993. "Archaeology and Resistance History in the Caribbean." The African Archaeological Review 11:175-195.

Alexander, Rani T. 2005. "Isla Cilvituk and the Difficulties of Spanish Colonization in Southwestern Campeche. Pp. 161-181 in The Postclassic to Spanish-Era Transition in Mesoamerica, edited by S. Kepecs and R. Alexander. Albuquerque: University of New Mexico Press.

Allen, Rebecca. 2010. "Rethinking Mission Land Use and the Archaeological Record in California: An Example from Santa Clara.” Historical Archaeology 44(2):72-96.

Ammann, Felipe Gaitán. 2012. "Besieged Genoese: An Archaeological Glimpse of the Slave Trade in Late-Seventeenth-Century Panama.” Historical Archaeology 46(3):27-46.

Andrews, Anthony P. 1981. "Historical Archaeology in Yucatan: A Preliminary Framework." Historical Archaeology 15(1):1-18.

Andrews, Anthony P. 1991. "The Rural Chapels and Churches of the Early Colonial Yucatán and Belize: An Archaeological Perspective." Pp. 355-374 in Columbian Consequences: The Spanish Borderlands in Pan-American Perspective. Vol. 3, edited by D.H. Thomas. Washington: Smithsonian Institution Press.

Bamforth, Douglas B. 1993. "Stone Tools, Steel Tools: Contact Period Household Technology at Helo." Pp. 181-199 in Ethnohistory and Archaeology: Approaches to Postcontact Change in the Americas, edited by J.D. Rogers and S.M. Wilson. New York: Plenum Press.

Baram, Uzi. 2012. "Cosmopolitan Meanings of Old Spanish Fields: Historical Archaeology of a Maroon Community in Southwest Florida. Historical Archaeology 46(1):108-122.

Barnadas, Josep M. 1984. "The Catholic Church in Colonial Spanish America.” Pp. 
511-540 in The Cambridge History of Latin America. Vol. 1, edited by L. Bethell. Cambridge: Cambridge University Press.

Bauer, Ralph. 2014. “Translating the 'Doctrine of Discovery': Spain, England, and Native Religions. Pp. 93-116 in Coloniality, Religion, and the Law in the Early Iberian World, edited by S. Arias and R. Marrero-Fente. Nashville: Vanderbilt University Press.

Beaudry, Mary C., Lauren J. Cook, and Stephen A. Mrozowski. 1991. "Artifacts and Active Voices: Material Culture as Social Discourse." Pp.150-191 in The Archaeology of Inequality, edited by R.H. McGuire and R. Paynter. Oxford: Blackwell.

Beck, Jr., Robin A., Christopher B. Rodning, and David G. Moore. 2010. "Limiting Resistance: Juan Pardo and the Shrinking of Spanish La Florida, 1566-68." Pp. 19-40 in Enduring Conquests: Rethinking the Archaeology of Resistance to Spanish Colonialism in the Americas, edited by M. Liebmann and M.S. Murphy. Santa Fe: School for Advanced Research Press.

Berdan, Frances F. 2005. The Aztecs of Central Mexico: An Imperial Society. Belmont: Wadsworth Cengage Learning.

Beverley, John. 1982. "El Salvador.” Social Text 5:55-72.

Brown, Jennifer S. 1996. "Reading Beyond the Missionaries, Dissecting Responses." 43(4):713-719.

Charlton, Thomas H., and Patricia Fournier. 2010. "Pots and Plots: The Multiple Roles of Early Colonial Red Wares in the Basin of Mexico (Identity, Resistance, Negotiation, Accommodation, Aesthetic Creativity, or Just Plain Economics?)." Pp. 127-148 in Enduring Conquests: Rethinking the Archaeology of Resistance to Spanish Colonialism in the Americas, edited by M. Liebmann and M.S. Murphy. Santa Fe: School for Advanced Research Press.

Chuchiak IV, John F. 2007. "The Sins of the Fathers: Franciscan Friars, Parish Priests, and the Sexual Conquest of the Yucatec Maya, 1545-1808. Ethnohistory 54(1):69-127.

Chuchiak IV, John F. 2010. "Writing as Resistance: Maya Graphic Pluralism and Indigenous Elite Strategies for Survival in Colonial Yucatan, 1550-1750." Ethnohistory 57(1):87-116.

Cohen-Williams, Anita S. 1992. "Common Maiolica Types of Northern New Spain." Historical Archaeology 26(1):119-130.

Clayton, Lawrence A. 2011. Bartolomé de las Casas and the Conquest of the Americas. 
Malden: Wiley-Blackwell.

Costello, JG. and D. Hornbeck. 1989. "Alta California: An Overview. Pp.303-331 in Columbian Consequences: Archaeological and Historical Perspectives on the Spanish Borderlands West. Vol. 1, edited by D.H. Thomas. Washington, Smithsonian Institution Press.

Cummins, Tom. 2002. "Forms of Andean Towns, Free Will, and Marriage." Pp. 199240 in The Archaeology of Colonialism, edited by C.L. Lyons and J.K. Papadopoulos. Los Angeles, Getty Research Institute.

Davidson, William Van. 1991. "Geographical Perspectives on Spanish-Pech (Paya) Indian Relationships, Northeast Honduras, Sixteenth Century. Pp. 205-226 in Columbian Consequences: The Spanish Borderlands in Pan-American Perspective. Vol. 3, edited by D.H. Thomas. Washington: Smithsonian Institution Press.

Dawdy, Shannon Lee. 2000. "Understanding Cultural Change through the Vernacular: Creolization in Louisiana. Historical Archaeology 34(3):107-123.

Deagan, Kathleen. 1978. "The Material Assemblage of $16^{\text {th }}$ Century Spanish Florida. Historical Archaeology 12:25-50.

Deagan, Kathleen. 1987. Artifacts of the Spanish Colonies of Florida and the Caribbean, 1500-1800. Vol. 1, Ceramics, Glassware, and Beads. Washington: Smithsonian Institution Press.

Deagan, Kathleen. 1988. "The Archaeology of the Spanish Contact Period in the Caribbean. Journal of Prehistory 2(2):187-233.

Deagan, Kathleen. 2007. "Eliciting Contraband through Archaeology: Illicit Trade in Eighteenth-Century St. Augustine.” Historical Archaeology 41(4):98-116.

Deagan, Kathleen. 2010. "Native American Resistance to Spanish Presence in Hispaniola and La Florida, ca. 1492-1650. Pp. 41-56 in Enduring Conquests: Rethinking the Archaeology of Resistance to Spanish Colonialism in the Americas, edited by M. Liebmann and M.S. Murphy. Santa Fe: School for Advanced Research Press.

Deetz, James. 1977. Small Things Forgotten. New York: Doubleday Publishing.

Delaunay, Amalia Nuevo. 2012. "Disarticulation of Aónikenk Hunter-Gatherer Lifeways during the Late Nineteenth and Early Twentieth Centuries: Two Case Studies from Argentinean Patagonia." Historical Archaeology 46(3):149-164.

de Souza, Marcos André Torres and Camilla Agostini. 2012. "Marks, Pots, and Pipes: 
Some Correlations between African Scarifications and Pottery Decoration in Eighteenth- and Nineteenth-Century Brazil.” Historical Archaeology 46(3):102123.

Dym, Jordana. 2006. Sovereign Villages to National States: City, State, and Federation in Central America, 1759-1839. Albuquerque: University of New Mexico Press.

Dym, Jordana. 2007. "Bourbon Reforms and City Government in Central America, 1759-1808." Pp.75-100, in Politics, Economy, and Society in Bourbon Central America, 1759-1821, edited by J. Dym. Boulder: University Press of Colorado.

Ewen, Charles R. 2000. "From Colonist to Creole: Archaeological Patterns of Spanish Colonization in the New World." Historical Archaeology 34(3):36--45.

Fairbanks, Charles H. 1984. "The Plantation Archaeology of the Southeastern Coast." Historical Archaeology 18(1):1-14.

Farnsworth, Paul. 1992. "Missions, Indians, and Cultural Continuity." Historical Archaeology 26(1):22-36.

Farnsworth, Paul and Jack S. Williams. 1992. "The Archaeology of the Spanish Colonial and Mexican Republican Periods: Introduction." Historical Archaeology 26(1):1-6.

Ferguson, Leland. 1980. "Looking for the 'Afro' in Colono-Indian Pottery. Pp. 14-28 in Archaeological Perspectives on Ethnicity in America, edited by R.L. Schuyler. Farmingdale: Baywood.

Ferguson, Leland. 1991. "Struggling with Pots in Colonial South Carolina." Pp. 28-39 in The Archaeology of Inequality, edited by R.H. McGuire and R. Paynter. Oxford: Blackwell.

Flory, Thomas. 1979. "Fugitive Slaves and Free Society: The Case of Brazil." The Journal of Negro History 64(2):116-130.

Fowler, William R. 1991. "The Political Economy of Indian Survival in SixteenthCentury Izalco, El Salvador.” Pp. 187-204 in Columbian Consequences: The Spanish Borderlands in Pan-American Perspective. Vol. 3, edited by D.H. Thomas. Washington: Smithsonian Institution Press.

Fowler, William R. 1993. “The Living Pay for the Dead: Trade, Exploitation, and Social Change in Early Colonial Izalco, El Salvador." Pp. 181-199 in Ethnohistory and Archaeology: Approaches to Postcontact Change in the Americas, edited by J. D. Rogers and S.M. Wilson. New York: Plenum Press.

Fowler, William R. 1995. Caluco: Historia y arqueologia de un pueblo Pipil en el siglo 
XVI. San Salvador: Patronato Pro-Patrimonio Cultural.

Fowler, William R. 2006. "Cacao Production, Tribute, and Wealth in Sixteenth-Century Izalcos, El Salvador." Pp. 307-321 in Chocolate in Mesoamerica: A Cultural History of Cacao, edited by C.L. McNeil. Gainesville: University of Florida Press.

Friedman, Jonathan. 1974. "Marxism, Structuralism and Vulgar Materialism.” Man 9(3):444-469.

Garman, James C. 1998. "Rethinking 'Resistant Accommodation': Toward an Archaeology of African-American Lives in Southern New England, 16381800." International Journal of Historical Archaeology 2(2):133-160.

Gasco, Janine. 1992. "Material Culture and Colonial Indian Society in Southern Mesoamerica: The View from Coastal Chiapas, Mexico." Historical Archaeology 67-74.

Gasco, Janine. 1993. "Socioeconomic Change within Native Society in Colonial Soconusco, New Spain." Pp. 163-180 in Ethnohistory and Archaeology: Approaches to Postcontact Change in the Americas, edited by J.D. Rogers and S.M. Wilson. New York: Plenum Press.

Gasco, Janine. 2005. "Spanish Colonialism and Processes of Social Change in Mesoamerica." Pp. 69-108 in The Archaeology of Colonial Encounters: Comparative Perspectives, edited by G.J. Stein. Santa Fe: School of American Research Press.

Gillenwater, Collin R. 2013. "Agency at Hacienda Pancota: Early Colonial Daily Consumption of a Contested Age and Material Culture." Master's thesis, Department of Sociology and Anthropology, Illinois State University, Normal.

Given, Michael. 2004. The Archaeology of the Colonized. New York: Routledge.

Gosden, Chris. 2004. Archaeology and Colonialism: Cultural Contact from 5000 BC to the Present. New York: Cambridge University Press.

Graham, Elizabeth. 1991. "Archaeological Insights into Colonial Period Maya Life at Tipu, Belize." Pp. 319-335 in Columbian Consequences: The Spanish Borderlands in Pan-American Perspective. Vol. 3, edited by D.H. Thomas. Washington: Smithsonian Institution Press.

Graham, Elizabeth. 1998. "Mission Archaeology." Annual Review of Anthropology 27:25-62.

Groover, Mark D. 1994. "Evidence for Folkways and Cultural Exchange in the $18^{\text {th }}$ - 
Century South Carolina Backcountry.” Historical Archaeology 28(1): 41-64.

Hanks, William F. 2010. Converting Words: Maya in the Age of the Cross. Berkeley: University of California Press.

Hester, TR. 1989. "Perspectives on the Material Culture of the Mission Indians of the Texas-Northeastern Mexico Borderlands." Pp. 213-229 in Columbian Consequences: Archaeological and Historical Perspectives on the Spanish Borderlands West. Vol. 1, edited by D.H. Thomas. Washington: Smithsonian Institution Press.

Hill, II, Robert M. 1991. "The Social Uses of Writing among the Colonial Cakchiquel Maya: Nativism, Resistance, and Innovation.” Pp. 283-299 in Columbian Consequences: The Spanish Borderlands in Pan-American Perspective. Vol. 3 , edited by D.H. Thomas. Washington: Smithsonian Institution Press.

Hill, II, Robert M. 1992. Colonial Cakchiquels: Highland Maya Adaptation to Spanish Rule 1600-1700. Fort Worth: Harcourt Brace Jovanovich.

Jackson, Robert H. 1995. "Introduction." Pp. vii-xviii in The New Latin American Mission History, edited by E. Langer and R.H. Jackson. Lincoln and London: University of Nebraska Press.

Jamieson, Ross W. 2001. "Majolica in the Early Colonial Andes: The Role of Panamanian Wares." Historical Archaeology 12(1):45-58.

Jones, Grant D. and David M. Pendergast. 1991. "The Native Context of Colonialism in Southern Mesoamerica and Central America: An Overview." Pp. 161-185 in Columbian Consequences: The Spanish Borderlands in Pan-American Perspective. Vol. 3, edited by D.H. Thomas. Washington: Smithsonian Institution Press.

Jordan, Stacey and Carmel Schrire. 1999. "Material Culture and the Roots of Colonial Society at the South African Cape of Good Hope." Pp. 241-272 in The Archaeology of Colonialism, edited by C.L. Lyons and J.K. Papadopoulos. Los Angeles: Getty Research Institute.

Kehoe, Alice B. 1979. "The Sacred Heart: A Case for Stimulus Diffusion." American Ethnologist 6(4):763-771.

Kelly, Kenneth. 1999. "Indigenous Responses to Colonial Encounters on the West African Coast: Hueda and Dahomey from the Seventeenth through Nineteenth Century." Pp. 96-120 in The Archaeology of Colonialism, edited by C.L. Lyons and J.K. Papadopoulos. Los Angeles: Getty Research Institute.

Kicza, John E. 1997. "Native American, African, and Hispanic Communities During the 
Middle Period in the Colonial Americas." Historical Archaeology 31(1):9-17.

Kizior, Liz. 2013. “Colonial Ethnic Identity, Urban Organization, and Ceramic Variability at Caluco, El Salvador." Master's thesis, Department of Sociology and Anthropology, Illinois State University, Normal.

Lees, William B., and Kathryn M. Kimery-Lees. 1979. "The Function of Colono-Indian Ceramics: Insights from Limerick Plantation, South Carolina." Historical Archaeology 13:1-13.

Leone, Mark. 1982. "Some Opinions about Recovering Mind." American Antiquity 47:742-60.

Liebmann, Matthew. 2010. "The Best of Times, the Worst of Times: Pueblo Resistance and Accommodation during the Spanish Reconquista of New Mexico.” Pp. 199222 in Enduring Conquests: Rethinking the Archaeology of Resistance to Spanish Colonialism in the Americas, edited by M. Liebmann and M.S. Murphy. Santa Fe: School for Advanced Research Press.

Lightfoot, Kent G., Antoinette Martinez, and Ann M. Schiff. 1998. "Daily Practice and Material Culture in Pluralistic Social Settings: An Archaeological Study of Culture Change and Persistence from Fort Ross, California." American Antiquity 63(2):199-222.

Lister, Florence C. and Robert H. Lister. 1974. "Maiolica in Colonial Spanish America." Historical Archaeology 8(1):17-52.

Lister, Florence C. and Robert H. Lister. 1976. "A Descriptive Dictionary for 500 Years of Spanish-Tradition Ceramics (13 ${ }^{\text {th }}$ through $18^{\text {th }}$ Centuries)." Historical Archaeology, Special Publication Series, Number 1:1-100.

Lister, Florence C. and Robert H. Lister. 1982. Sixteenth Century Maiolica Pottery in the Valley of Mexico. Tucson: University of Arizona Press.

Llerena, Laura León. 2014. "Narrating Conversion: Idolatry, the Sacred, and the Ambivalences of Christian Evangelization in Colonial Peru." Pp. 117-137 in Colonality, Religion, and the Law in the Early Iberian World, edited by S. Arias and R. Marrero-Fente. Nashville: Vanderbilt University Press.

Lockhart, James. 1992. The Nahuas after the Conquest: A Social and Cultural History of the Indians of Central Mexico, Sixteenth Through Eighteenth Centuries. Stanford: Stanford University Press.

MacLeod, Murdo J. 2008. Spanish Central America: A Socioeconomic History, 15201720. Austin: University of Texas Press. 
Malkin, Irad. 1999. “A Colonial Middle Ground: Greek, Etruscan, and Local Elites in the Bay of Naples." Pp. 151-180 in The Archaeology of Colonialism, edited by C.L. Lyons and J.K. Papadopoulos. Los Angeles: Getty Research Institute.

Mann, Rob. 2012. "Plazas and Power: Canary Islanders at Galveztown, an EighteenthCentury Spanish Colonial Outpost in Louisiana." Historical Archaeology 46(1):49-61.

Martín, Juan G. and Beatriz Rovira. 2012. “The Panamá Viejo Archaeological Project: More than a Decade of Research and Management of Heritage Resources." Historical Archaeology 46(3):16-26.

Matthews, Christopher N. 2010. The Archaeology of American Capitalism. Gainesville: University Press of Florida.

McAlister, Lyle N. 1984. Spain and Portugal in the New World, 1492-1700. Minneapolis: University of Minnesota Press.

McEwan, Bonnie G. 1991. "The Archaeology of Women in the Spanish New World." Historical Archaeology 25(4):33-41.

McEwan, Bonnie G. 1992. "The Role of Ceramics in Spain and Spanish America during the $16^{\text {th }}$ century." Historical Archaeology 26(1):92-108.

McGuire, Randall H. 1993. "Archaeology and Marxism.” Archaeological Method and Theory 5:101-157.

Murphy, Melissa S., Elena Goycochea, and Guillermo Cock. 2010. Resistance, Persistence, and Accommodation at Puruchuco-Huaquerones, Peru. Pp. 57-76 in Enduring Conquests: Rethinking the Archaeology of Resistance to Spanish Colonialism in the Americas, edited by M. Liebmann and M.S. Murphy. Santa Fe: School for Advanced Research Press.

Nassaney, Michael S. 2008. "Identity Formation at a French Colonial Outpost in the North American Interior." International Journal of Historical Archaeology 12:297-318.

Newman, Elizabeth Terese. 2010. "Butchers and Shamans: Zooarchaeology at a Central Mexican Hacienda.” Historical Archaeology 44(2):35-50.

Noel-Hume, Ivor. 1962. "An Indian Ware of the Colonial Period." Quarterly Bulletin of the Archaeological Society of Virginia 17(1):2-12.

Orser, Jr., Charles E. 1991. “The Continued Pattern of Dominance: Landlord and 
Tenant on the Postbellum Cotton Plantation." Pp. 40-54 in The Archaeology of Inequality, edited by R.H. McGuire and R.Paynter. Cambridge: Basil Blackwell Inc.

Orser, Jr, Charles E. 1995. Historical Archaeology. 2nd ed. Upper Saddle River: Pearson Prentice Hall.

Orser, Jr, Charles E. 1996. "The Haunts of Historical Archaeology.” Pp. 57-88 in A Historical Archaeology of the Modern World, edited by C.E. Orser, Jr. New York: Plenum Press.

Orser, Jr, Charles E. 2004. Race and Practice in Archaeological Interpretation. Philadelphia: University of Pennsylvania Press.

Orser, Jr, Charles E. 2005. "The Material Implications of Colonialism in Early Nineteenth-Century Ireland." Pp. 66-83 in Was Ireland a Colony?: Economics, Politics and Culture in Nineteenth-Century Ireland, edited by T. McDonough. Portland: Irish Academic Press.

Orser, Jr., Charles E. and Pedro P. A. Funari. 2001. "Archaeology and Slave Resistance and Rebellion." World Archaeology 33(1):61-72.

Ortner, Sherry B. 1984. "Theory in Anthropology since the Sixties." Comparative Studies in Society and History 26(1):126-166.

Overmyer-Velázquez, Rebecca. 2005. "Christian Morality in New Spain: The Nahua Woman in the Franciscan Imagery." In Bodies in Contact: Rethinking Colonial Encounters in World History. Durham: Duke University Press.

Palka, Joel W. 2009. "Historical Archaeology of Indigenous Culture Change in Mesoamerica." Journal of Archaeological Research 17(4):297-346.

Pauketat, Tim. 2001. "Practice and History in Archaeology: An emerging paradigm." Anthropological Theory 1(1):73-98.

Peel, J.D.Y. 1995. "For Who Hath Despised the Day of Small Things? Missionary Narratives and Historical Anthropology." Comparative Studies in Society and History 37(3):581-607.

Pendergast, David M. 1991. "The Southern Maya Lowlands Contact Experience: The View from Lamanai, Belize.” Pp. 337-354 in Columbian Consequences: The Spanish Borderlands in Pan-American Perspective. Vol. 3, edited by D.H. Thomas. Washington: Smithsonian Institution Press.

Pinto, Gloria Lara. 1991. "Change for Survival: The Case of the Sixteenth-Century 
Indigenous Populations of Northeast and Mideast Honduras." Pp. 227-243 in Columbian Consequences: The Spanish Borderlands in Pan-American Perspective. Vol. 3, edited by D.H. Thomas. Washington: Smithsonian Institution Press.

Preucel, Robert W. 2010. "Becoming Navajo: Refugees, Pueblitos, and Identity in the Dinétah." Pp. 223-242 in Enduring Conquests: Rethinking the Archaeology of Resistance to Spanish Colonialism in the Americas, edited by M. Liebmann and M.S. Murphy. Santa Fe: School for Advanced Research Press.

Quilter, Jeffrey. 2010. "Cultural Encounters at Magdalena de Cao Viejo in the Early Colonial Period." Pp. 103-126 in Enduring Conquests: Rethinking the Archaeology of Resistance to Spanish Colonialism in the Americas, edited by M. Liebmann and M.S. Murphy. Santa Fe: School for Advanced Research Press.

Restall, Matthew. 2003. Seven Myths of the Spanish Conquest. New York: Oxford University Press.

Rice, Prudence M. 2013. "Political-Ecology Perspectives on New World Loza (Majolica)." International Journal of Historical Archaeology 17:651-683.

Rodríguez-Alegría, Enrique. 2008. "Narratives of Conquest, Colonialism, and CuttingEdge Technology." American Anthropologist 110(1):33-43.

Rodríguez-Alegría, Enrique. 2010. "Incumbents and Challengers: Indigenous Politics and the Adoption of Spanish Material Culture in Colonial Xaltocan, Mexico." Historical Archaeology 44(2):51-71.

Rodríguez-Alegría, Enrique, Hector Neff, and Michael D. Glascock. 2003. "Indigenous Ware or Spanish Import? The Case of Indígena Ware and Approaches to Power in Colonial Mexico.” Latin American Antiquity 14(1):67-81.

Roberts Thompson, Amanda D. 2012. "Evaluating Spanish Colonial Alternative Economies in the Archaeological Record." Historical Archaeology 46(4):48-69.

Rothschild, Nan A. 2006. "Colonialism, Material Culture, and Identity in the Rio Grande and Hudson River Valleys." International Journal of Historical Archaeology 10(1):73-108.

Sampeck, Kathryn E. 2007. "Late Postclassic to Colonial Landscapes and Political Economy of the Izalcos Region, El Salvador." Ph.D. dissertation, Tulane University, New Orleans. ProQuest Dissertations and Theses.

Sampeck, Kathryn E. 2015. "Chronology and Use of Guatemalan Maiolica: Ceramics as Reducción in the Izalcos Region of El Salvador." Historical Archaeology 49(2): 18-49. 
Saunders, Rebecca. 2001. "Negotiated Tradition? Native American Pottery in the Mission Period in La Florida." Pp. 77-93 in The Archaeology of Traditions: Agency and History before and after Columbus, edited by T. Pauketat. Gainesville: University Press of Florida.

Saunders, Rebecca. 2012. "Deep Surfaces: Pottery Decoration and Identity in the Mission Period." Historical Archaeology 46(1):94-107.

Service, Elman R. 1955. "Indian-European Relations in Colonial Latin America." American Anthropologist 57(3):411-425.

Shea, John Gilmary. 1969. Religion in America: Catholic Missions among the Indian Tribes of the United States, 1529-1854. New York: Arno Press.

Sheptak, Russell. Sheptak, Rosemary A. Joyce, and Kira Blaisdell-Sloan. 2010. "Pragmatic Choices, Colonial Lives: Resistance, Ambivalence, and Appropriation in Northern Honduras." Pp. 149-172 in Enduring Conquests: Rethinking the Archaeology of Resistance to Spanish Colonialism in the Americas, edited by M. Liebmann and M.S. Murphy. Santa Fe: School for Advanced Research Press.

Silliman, Stephen. 2001. "Agency, Practical Politics, and the Archaeology of Culture Contact." Journal of Social Archaeology 1(2):190-209.

Skowronek, Russell K. 1998. "The Spanish Philippines: Archaeological Perspectives on Colonial Economics and Society." International Journal of Historical Archaeology 2(1):45-71.

Stear, Ezekiel. 2014. "Voices of the Altepetl: Nahua Epistemologies and Resistance in the Anales de Juan Bautista." Pp. 51-70 in Coloniality, Religion, and the Law in the Early Iberian World, edited by S. Arias and R. Marrero-Fente. Nashville: Vanderbilt University Press.

Stein, Gil J. 1999. "Colonies without Colonialism: A Trade Diaspora Model of Fourth Millennium B.C. Mesopotamian Enclaves in Anatolia.” Pp. 27-64 in The Archaeology of Colonialism, edited by C.L. Lyons and J.K. Papadopoulos. Los Angeles: Getty Research Institute.

Stein, Gil J. 2005. "The Political Economy of Mesopotamian Colonial Encounters.” Pp. 143-170 in The Archaeology of Colonial Encounters: Comparative Perspectives, edited by G.J. Stein. Santa Fe: School of American Research Press.

Sturtevant, William C. 1962. "Spanish-Indian Relations in Southeastern North America." Ethnohistory 9(1):41-94.

Symanski, Luís Cláudio P. 2012. "The Place of Strategy and the Spaces of Tactics: 
Structures, Artifacts, and Power Relations on Sugar Plantations of West Brazil." Historical Archaeology 46(3):124-148.

Upton, Dell. 1988. "White and Black Landscapes in Eighteenth Century Virginia." Pp. 357-370 in Material Life in America, 1600-1860, edited by R.B. St. George.

Boston: Northeastern University Press.

Upton, Dell. 1990. "Imaging the Early Virginia Landscape." Pp. 71-86 in Earth Patterns: Essays in Landscape Archaeology, edited by W.M. Kelso and R. Most. Charlottesville: University Press of Virginia.

Usner, Jr., Daniel H. 1987. "The Frontier Exchange Economy of the Lower Mississippi Valley in the Eighteenth Century." The William and Mary Quarterly, Third Series 44(2):165-192.

Van Buren, Mary and Brendan J.M. Weaver. 2012. "Contours of Labor and History: A Diachronic Perspective on Andean Mineral Production and the Making of Landscapes in Porco, Bolivia.” Historical Archaeology 46(3):79-101.

van Dommelen, Peter. 1999. "Ambiguous Matters: Colonialism and Local Identities in Punic Sardinia.” Pp. 121-150 in The Archaeology of Colonialism, edited by C.L. Lyons and J.K. Papadopoulos. Los Angeles: Getty Research Institute.

van Dommelen, Peter. 2005. "Colonial Interactions and Hybrid Practices: Phoenician and Carthaginian Settlement in the Ancient Mediterranean." Pp. 109-142 in The Archaeology of Colonial Encounters: Comparative Perspectives, edited by G.J. Stein. Santa Fe: School of American Research Press.

Van Oss, A.C. 1986. Catholic Colonialism: A Parish History of Guatemala, 15241821. New York: Cambridge University Press.

Van Oss, A.C. 2003. Church and Society in Spanish America. Cedla: Aksant Academic Publishers.

Verhagen, Inez Leontine. 1997. "Caluco, El Salvador: The Archaeology of a Colonial Indian Town in Comparative Perspective," vol. 1. Ph.D. dissertation, Vanderbilt University, Nashville. ProQuest Dissertations and Theses.

Voss, Barbara L. 2010. "The Archaeology of indigenous Heritage at Spanish-Colonial Military Settlements." Pp. 243-266 in Enduring Conquests: Rethinking the Archaeology of Resistance to Spanish Colonialism in the Americas, edited by M. Liebmann and M.S. Murphy. Santa Fe: School for Advanced Research Press.

Voss, Barbara. 2012. "Status and Ceramics in Spanish Colonial Archaeology." Historical Archaeology 46(2):39-54. 
Weeks, John M. and Nancy J. Black. 1991. "Mercedarian Missionaries and the Transformation of Lenca Indian Society in Western Honduras, 1550-1700.” Pp. 245-261 in Columbian Consequences: The Spanish Borderlands in PanAmerican Perspective. Vol. 3, edited by D.H. Thomas. Washington: Smithsonian Institution Press.

Weik, Terry. 1997. "The Archaeology of Maroon Societies in the Americas: Resistance, Cultural Continuity, and Transformation in the African Diaspora." Historical Archaeology 31(2):81-92.

Wernke, Steven A. 2010. "Convergences: Producing Early Colonial Hybridity at a Doctrina in Highland Peru." Pp. 77-102 in Enduring Conquests: Rethinking the Archaeology of Resistance to Spanish Colonialism in the Americas, edited by M. Liebmann and M.S. Murphy. Santa Fe: School for Advanced Research Press.

Wolf, Eric R. 1982. Europe and the People Without History. Berkeley: University of California Press.

Wood, Margaret C. 2012. "Mapping the Complexities of Race on the Landscape of the Colonial Caribbean, United States Virgin Islands, 1770-1917." Historical Archaeology 46(4):112-134.

Zeitlin, Judith Francis and Lillian Thomas. 1997. "Indian Consumers on the Periphery of the Colonial Market System: Tracing Domestic Economic Behavior in a Tehuantepec Hamlet." Pp. 5-16 in Approaches to the Historical Archaeology of Mexico, Central, and South America, edited by J. L. Gasco, G. C. Smith, and P. Fournier-Garcia. Los Angeles: Institute of Archaeology, University of California. 
APPENDIX A

COMPLETE CERAMIC INVENTORY 


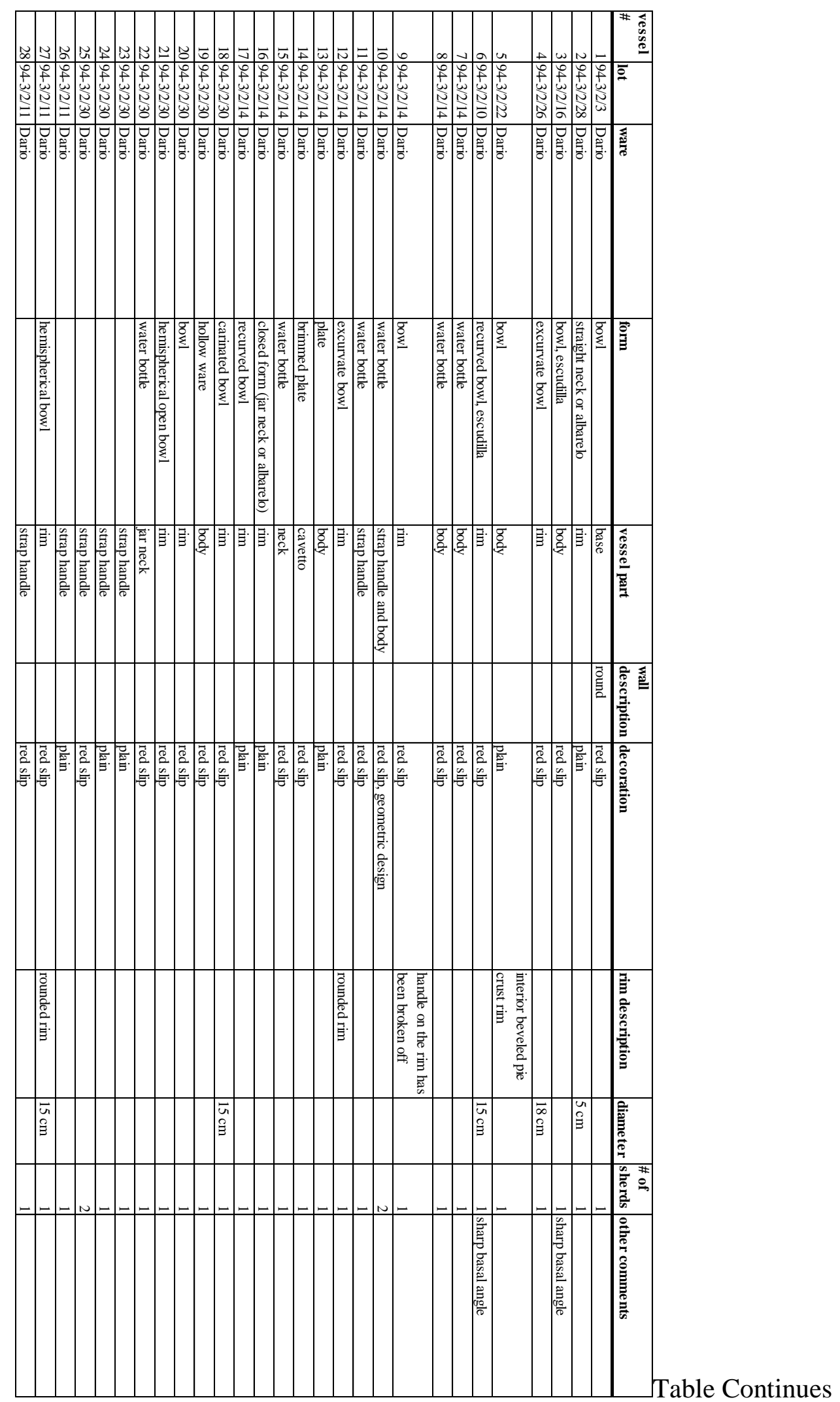




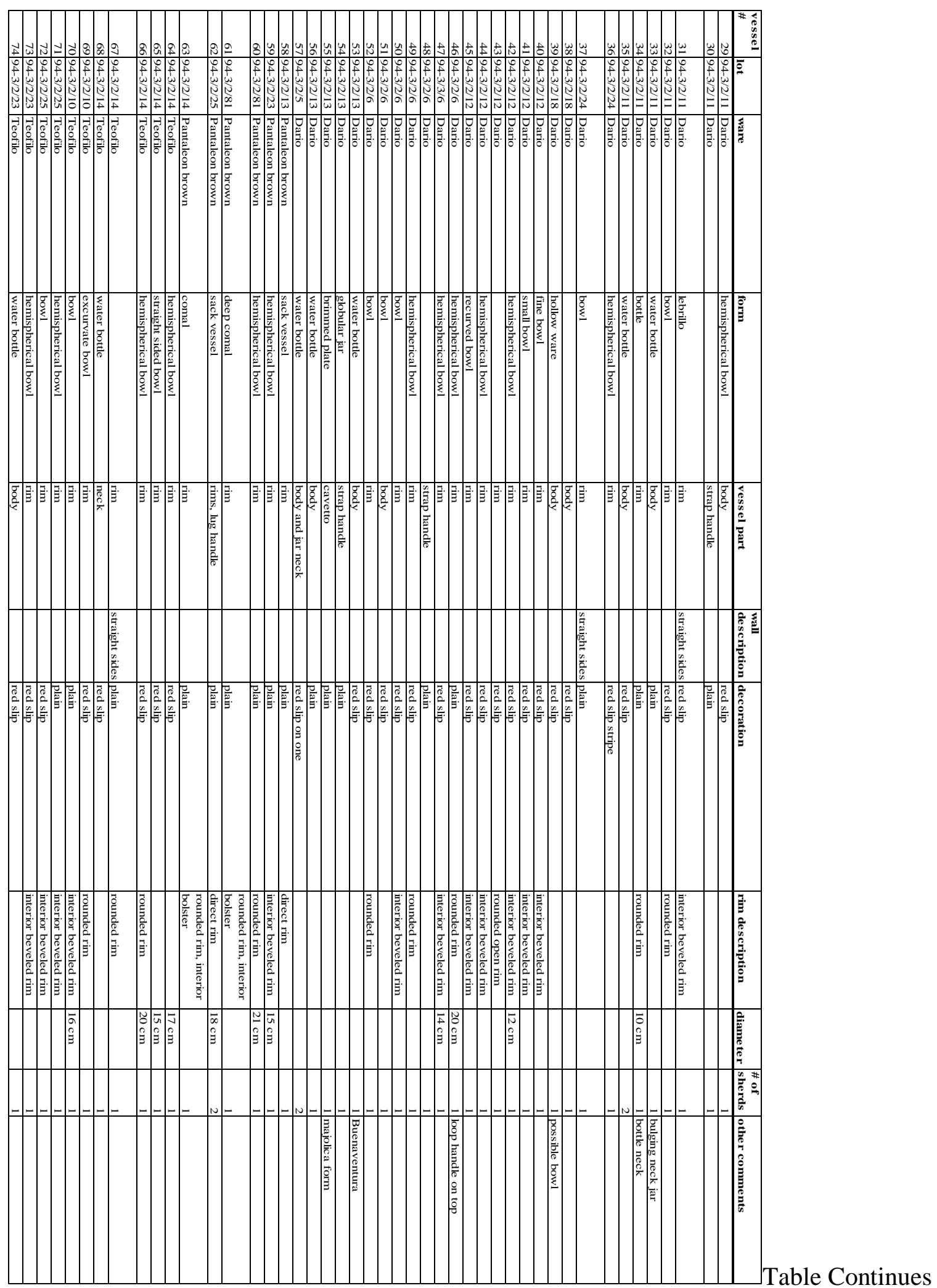




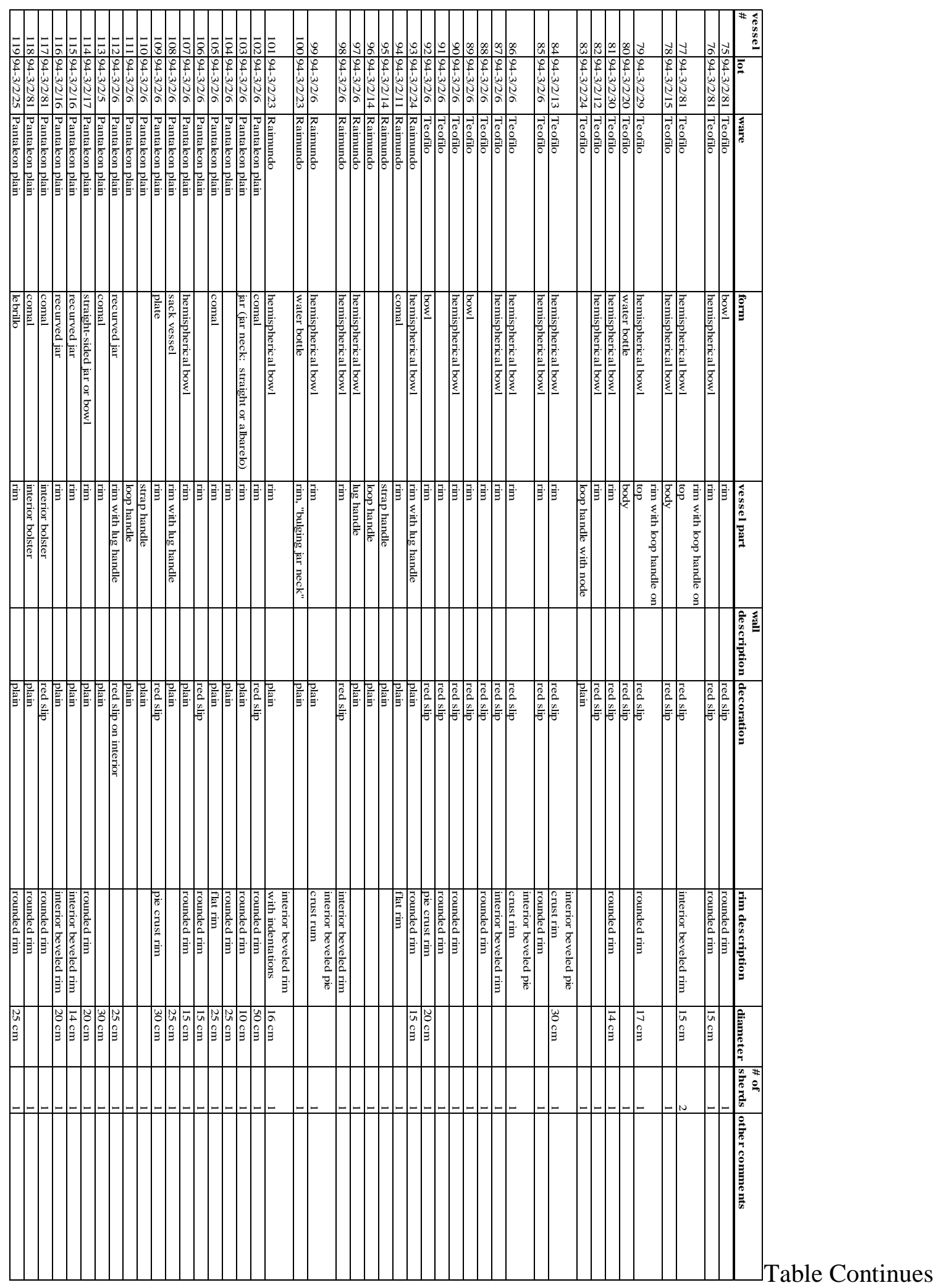




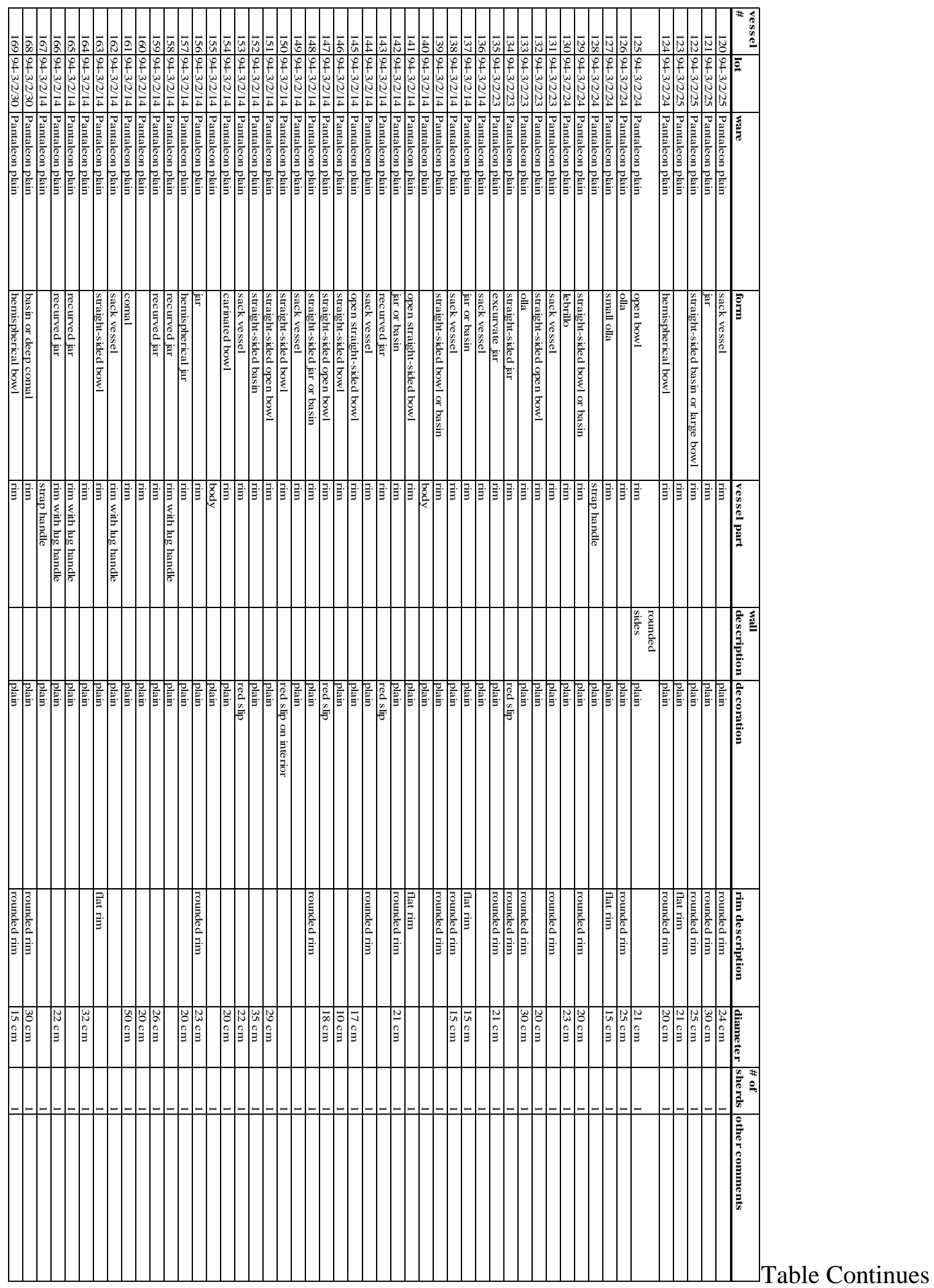




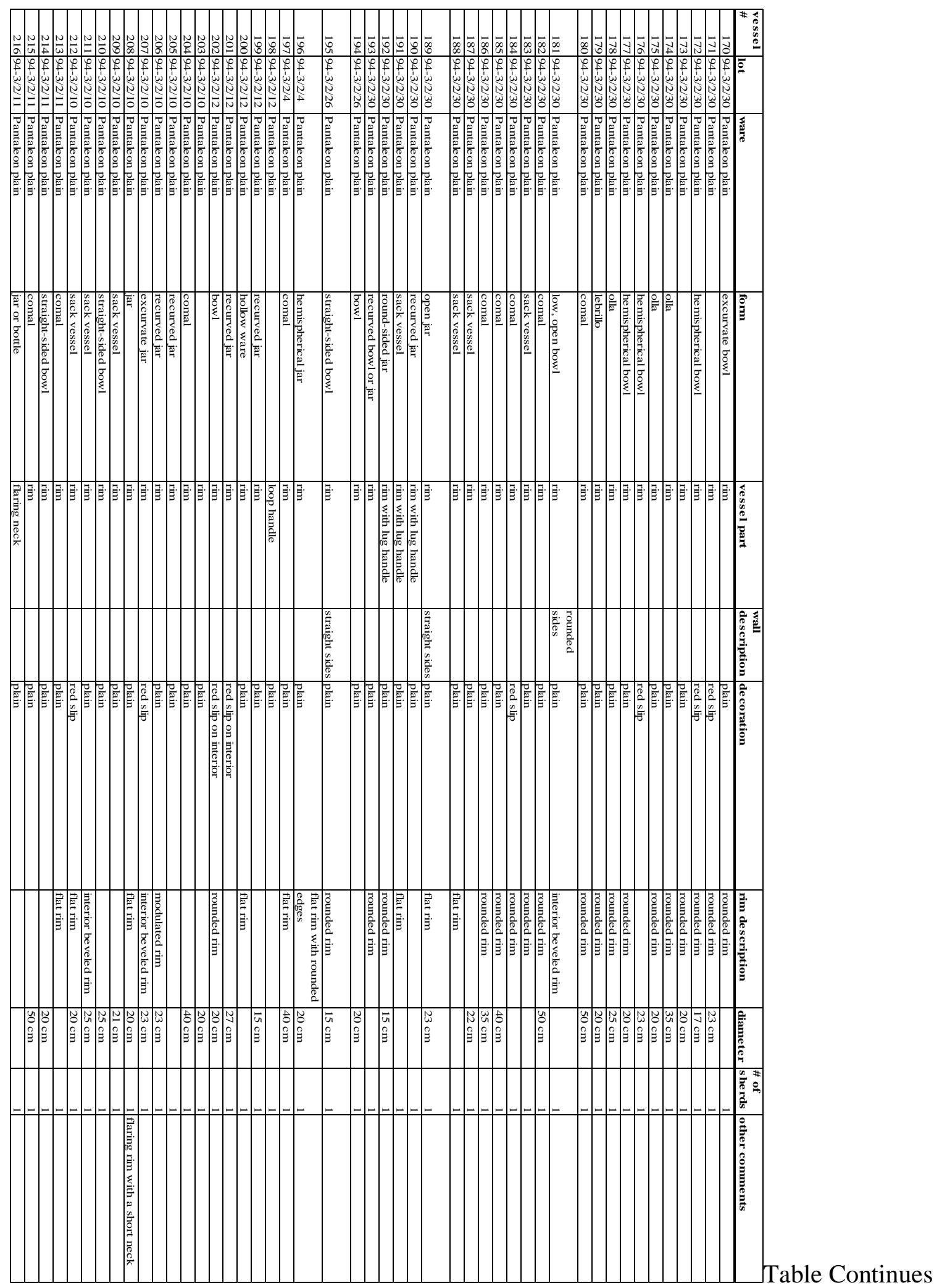




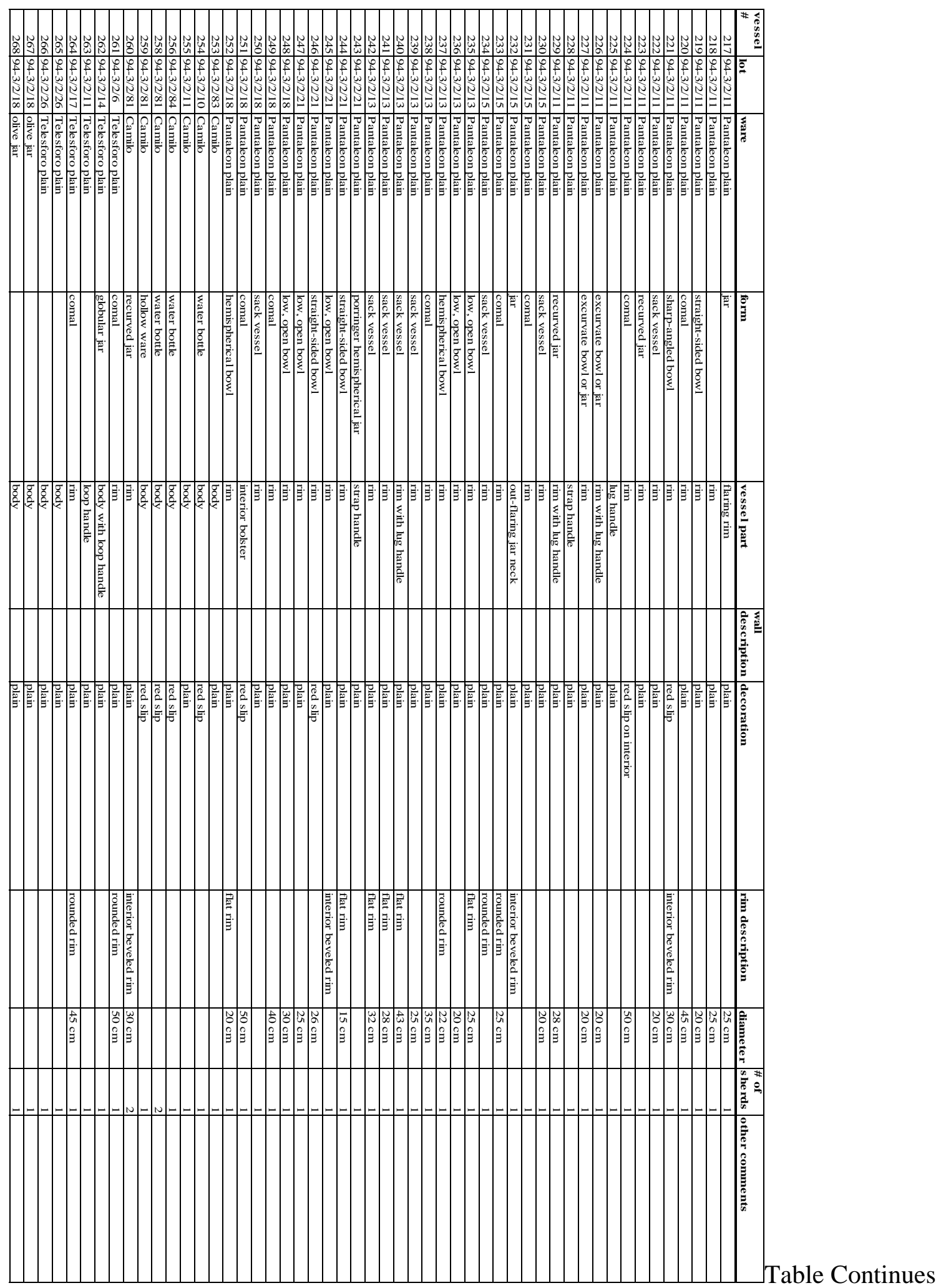




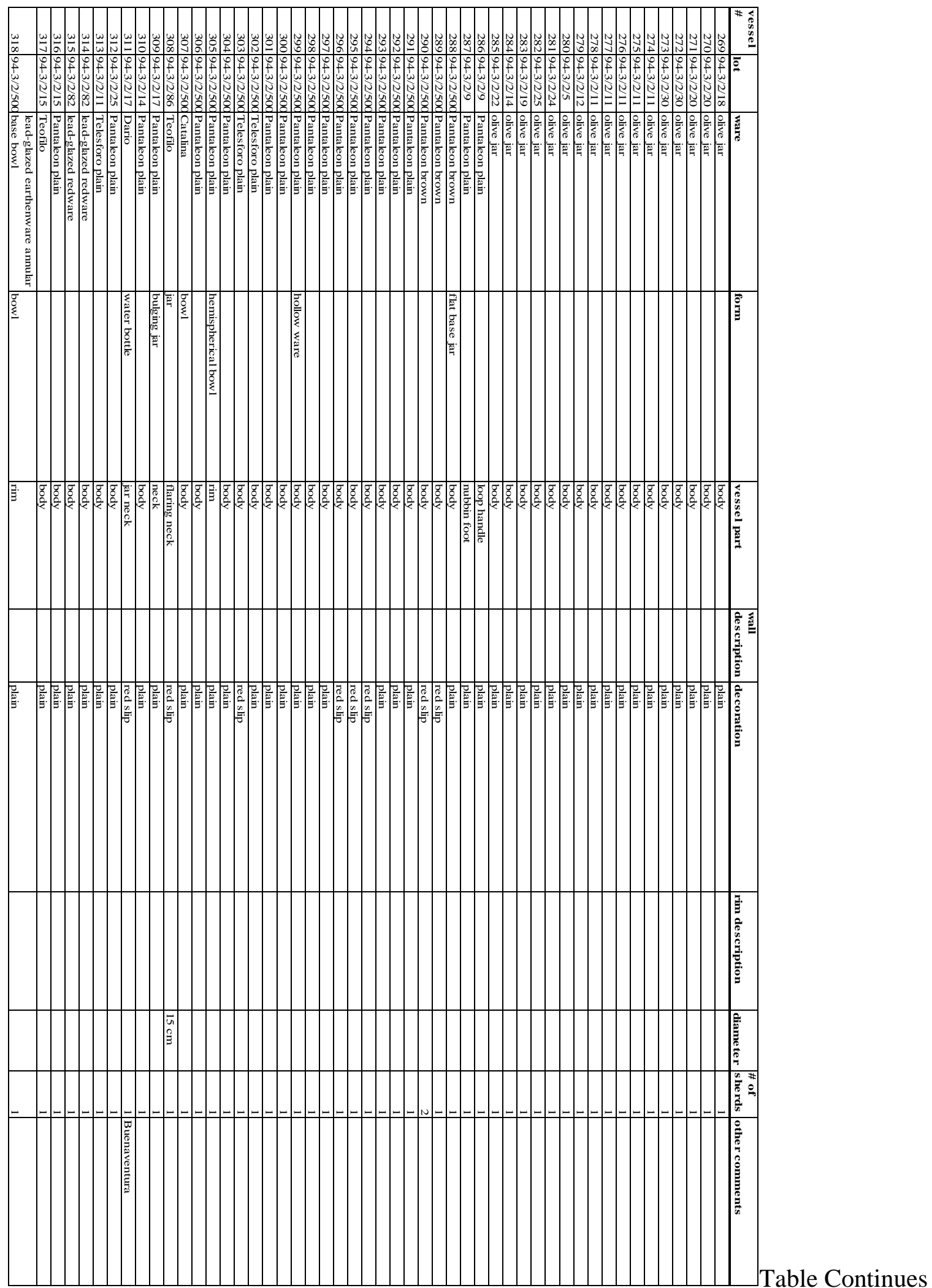




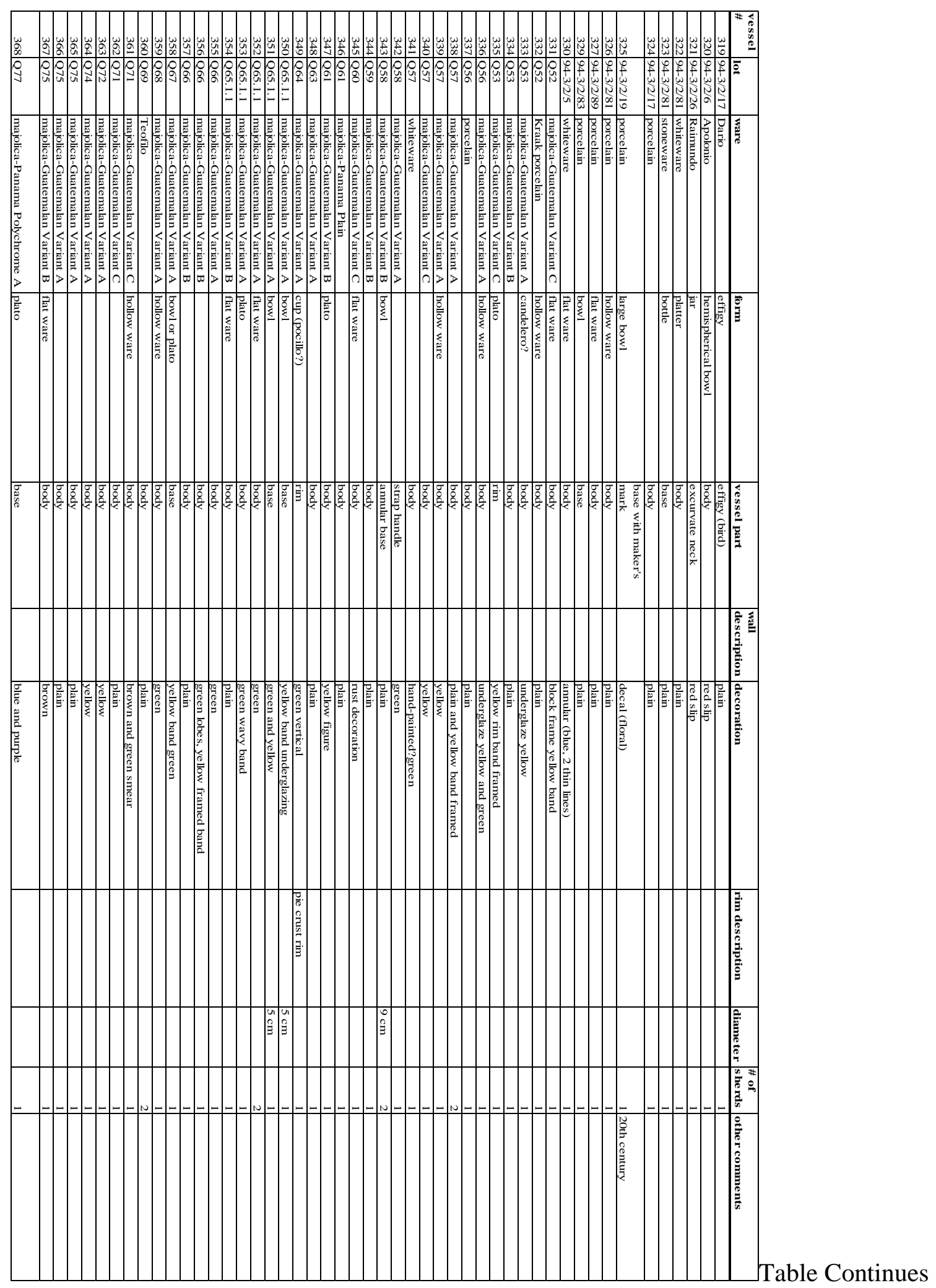




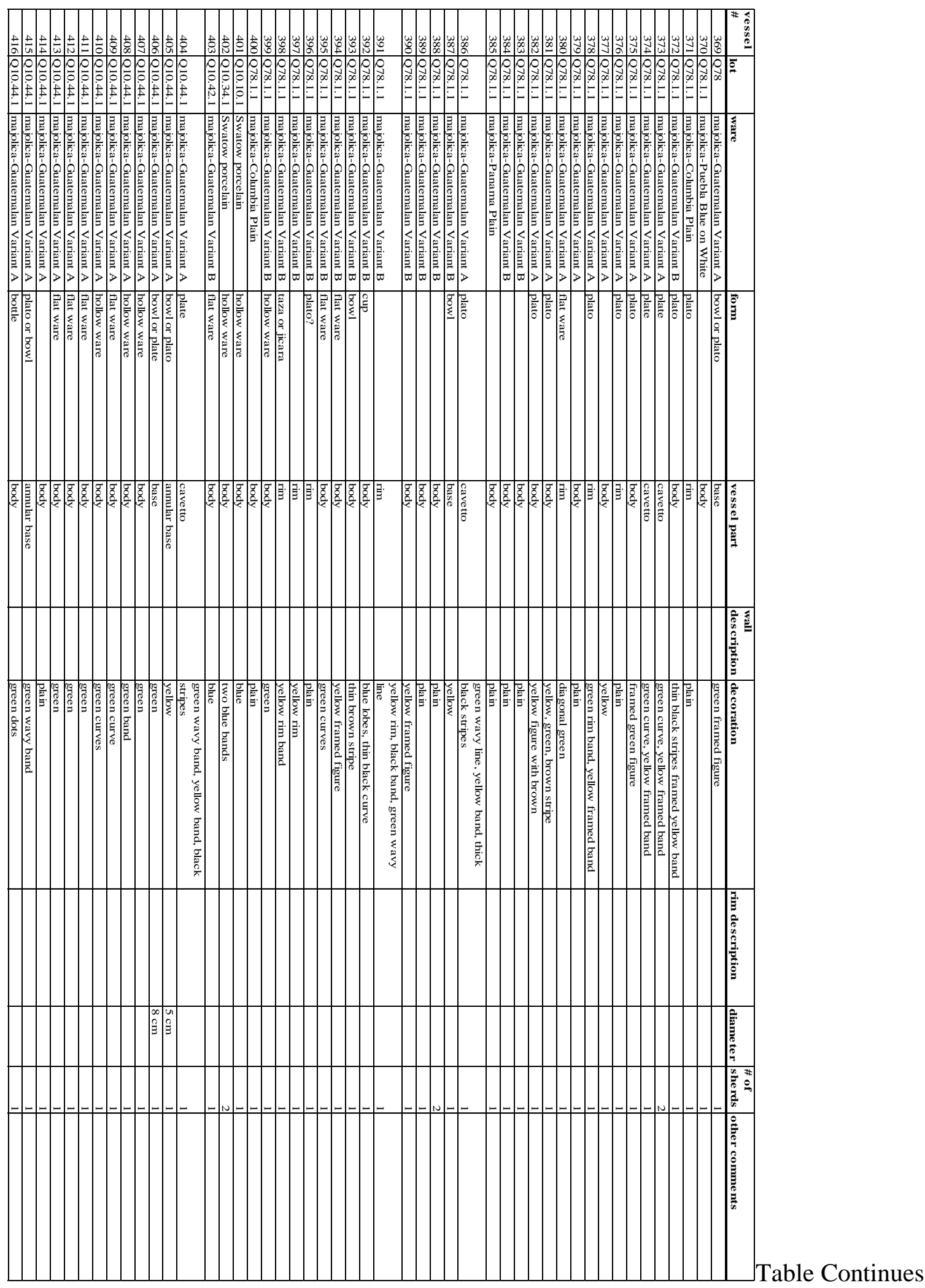




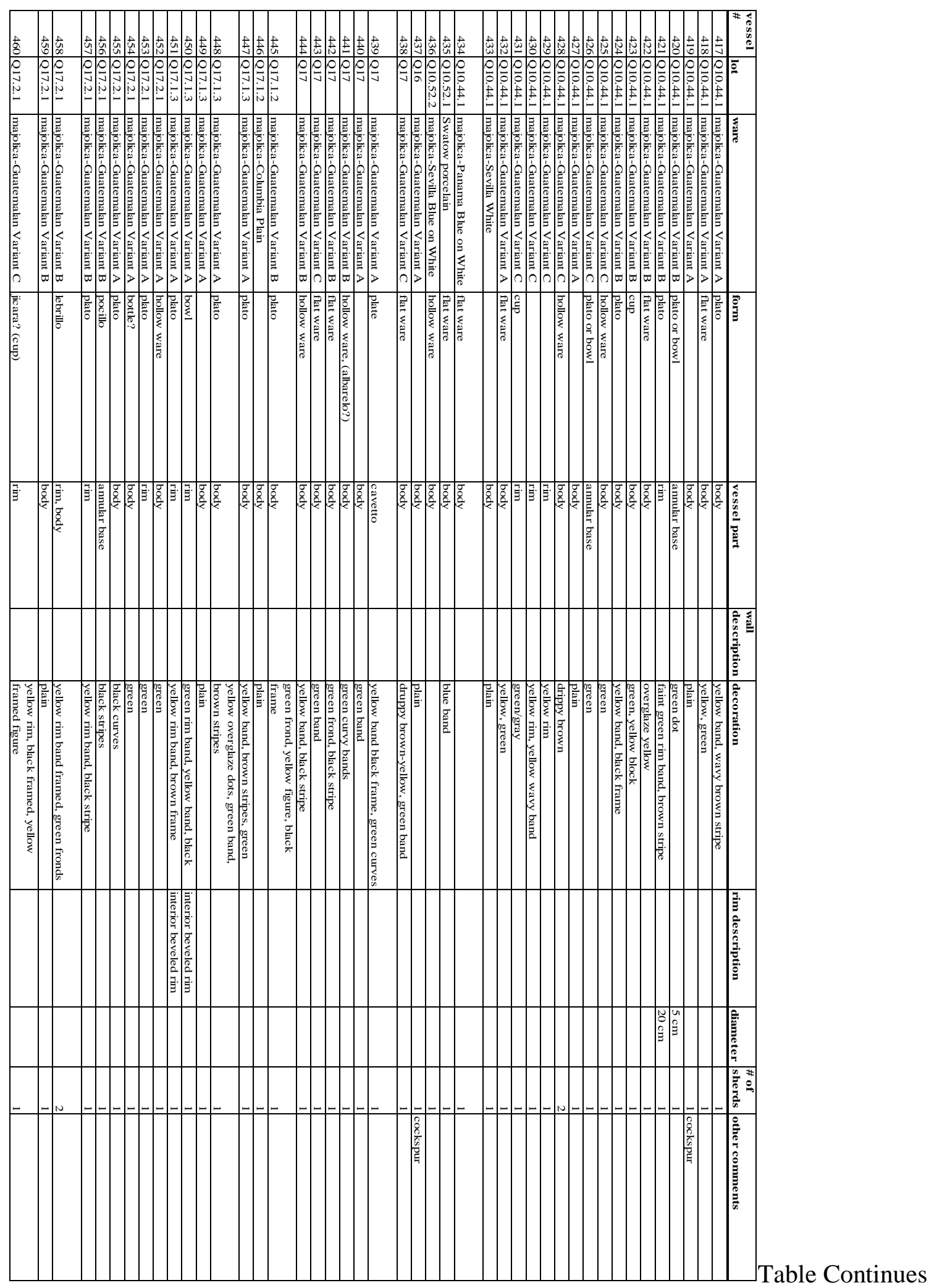




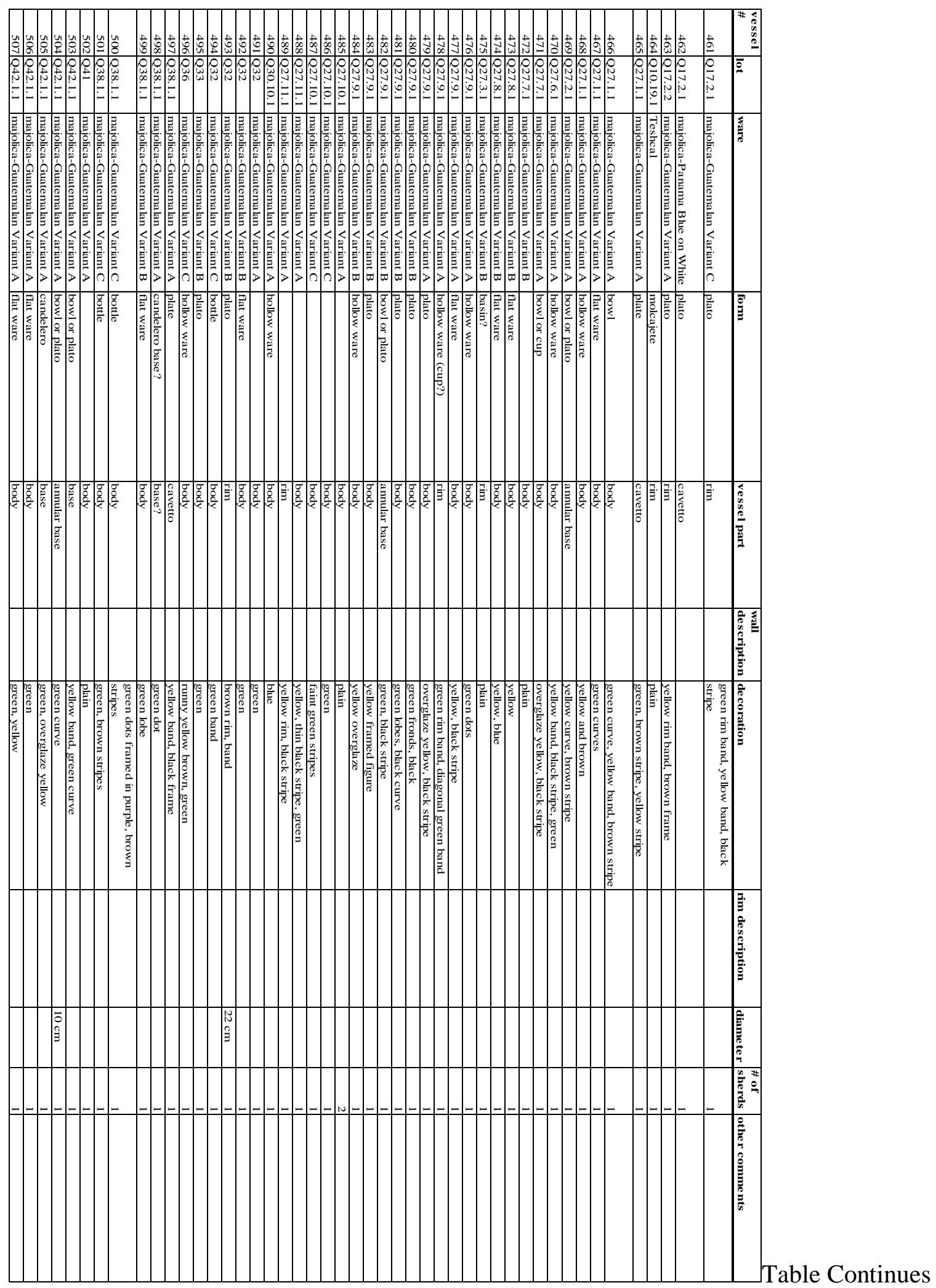




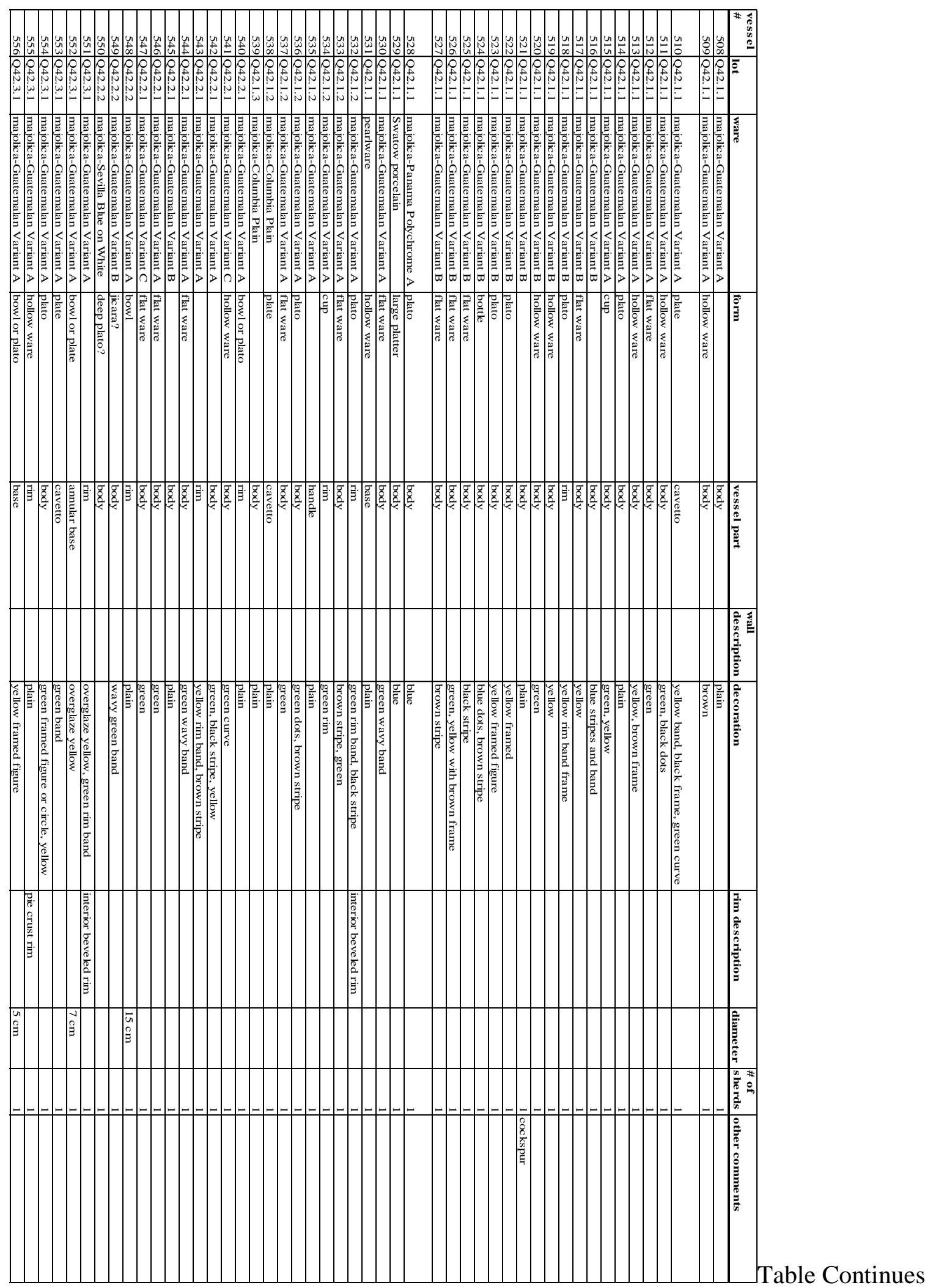




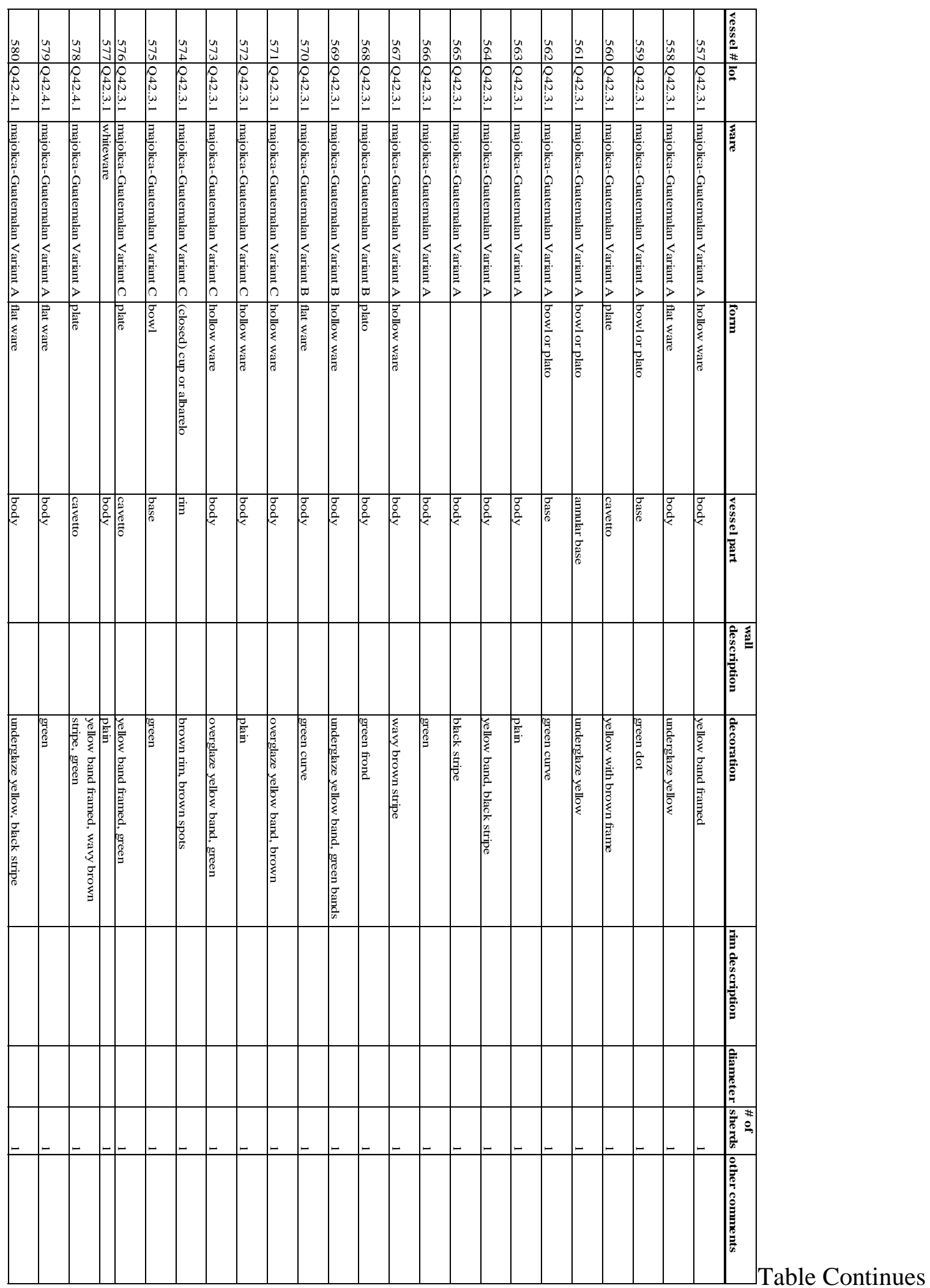



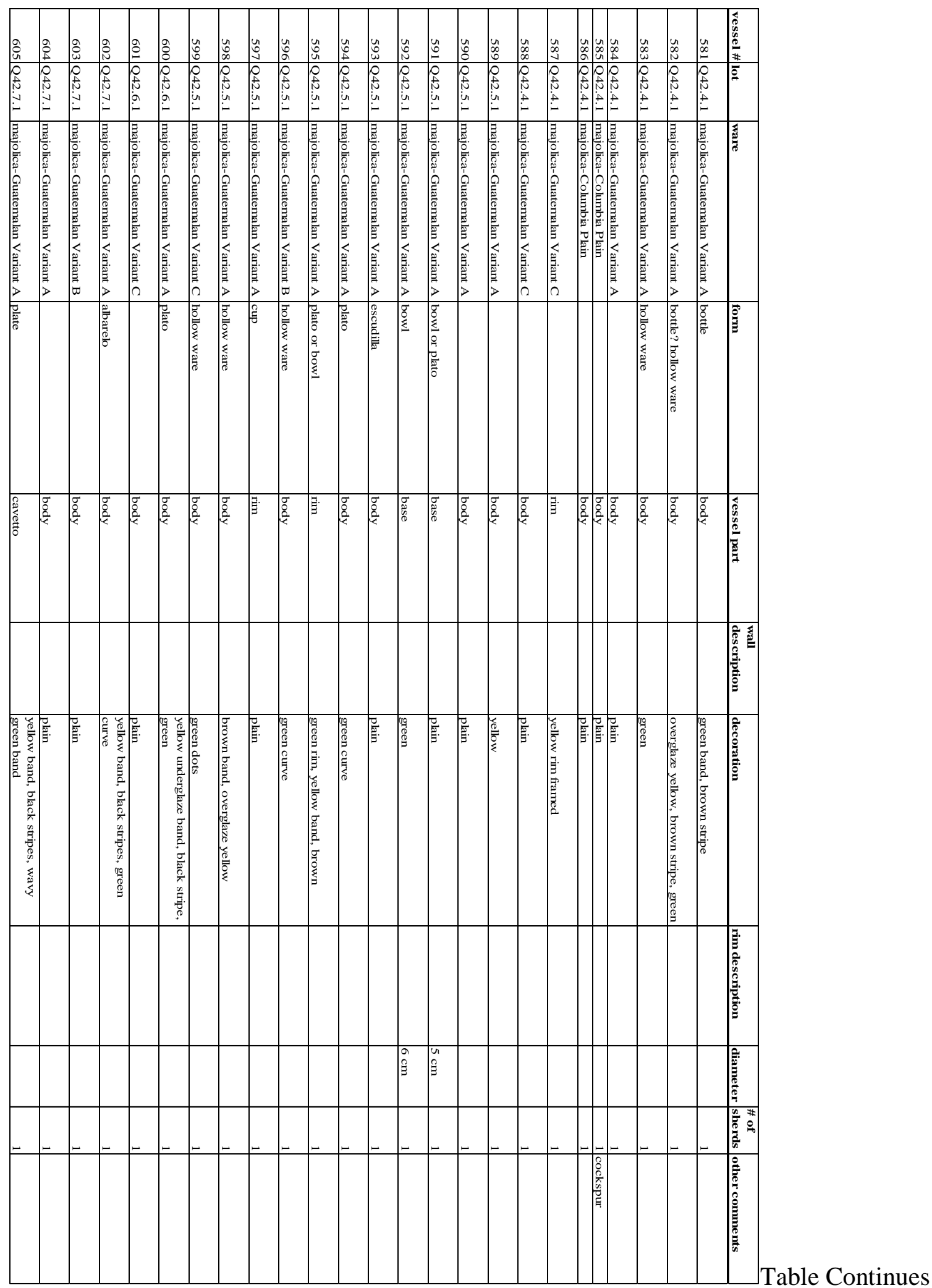


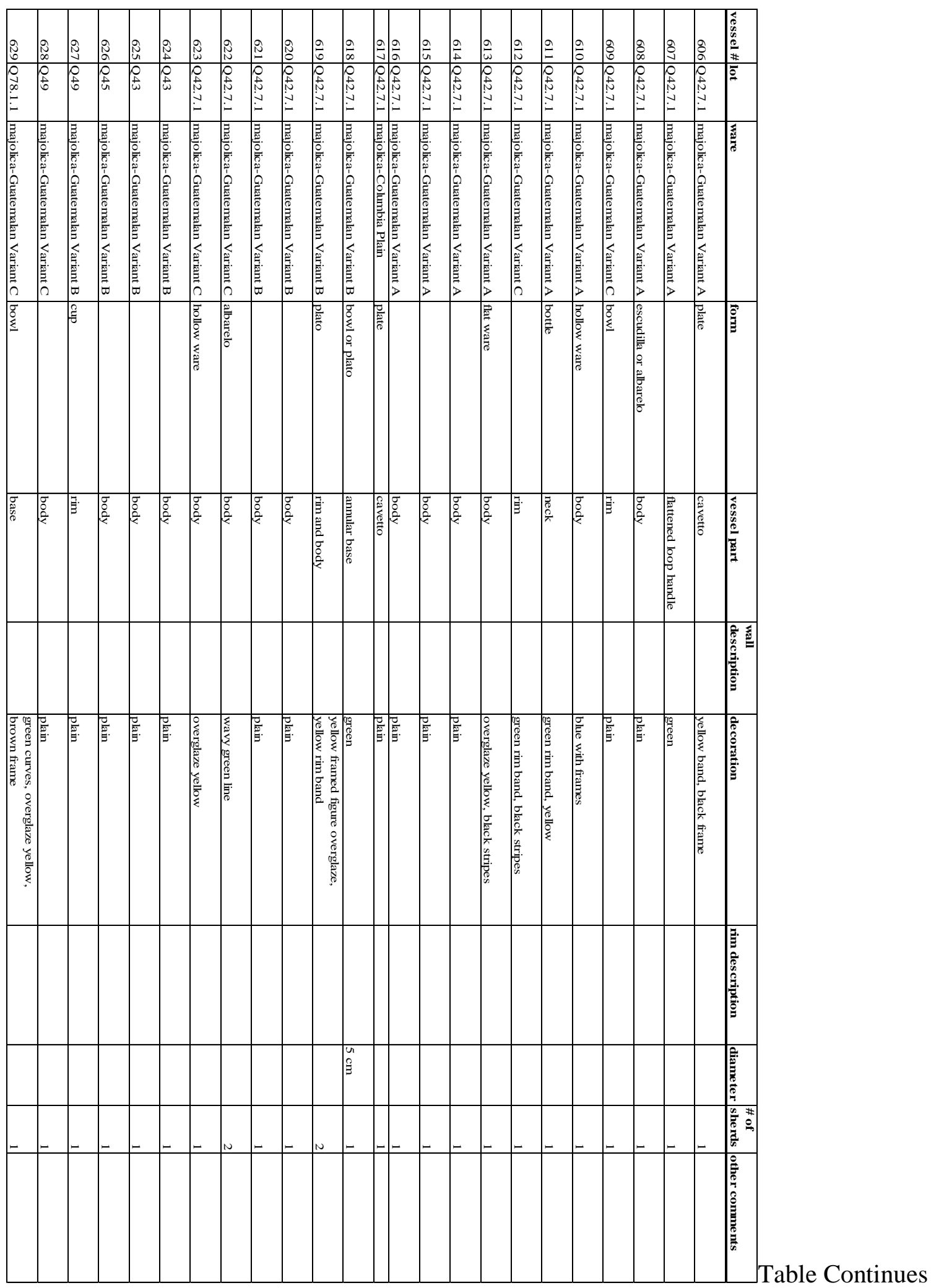



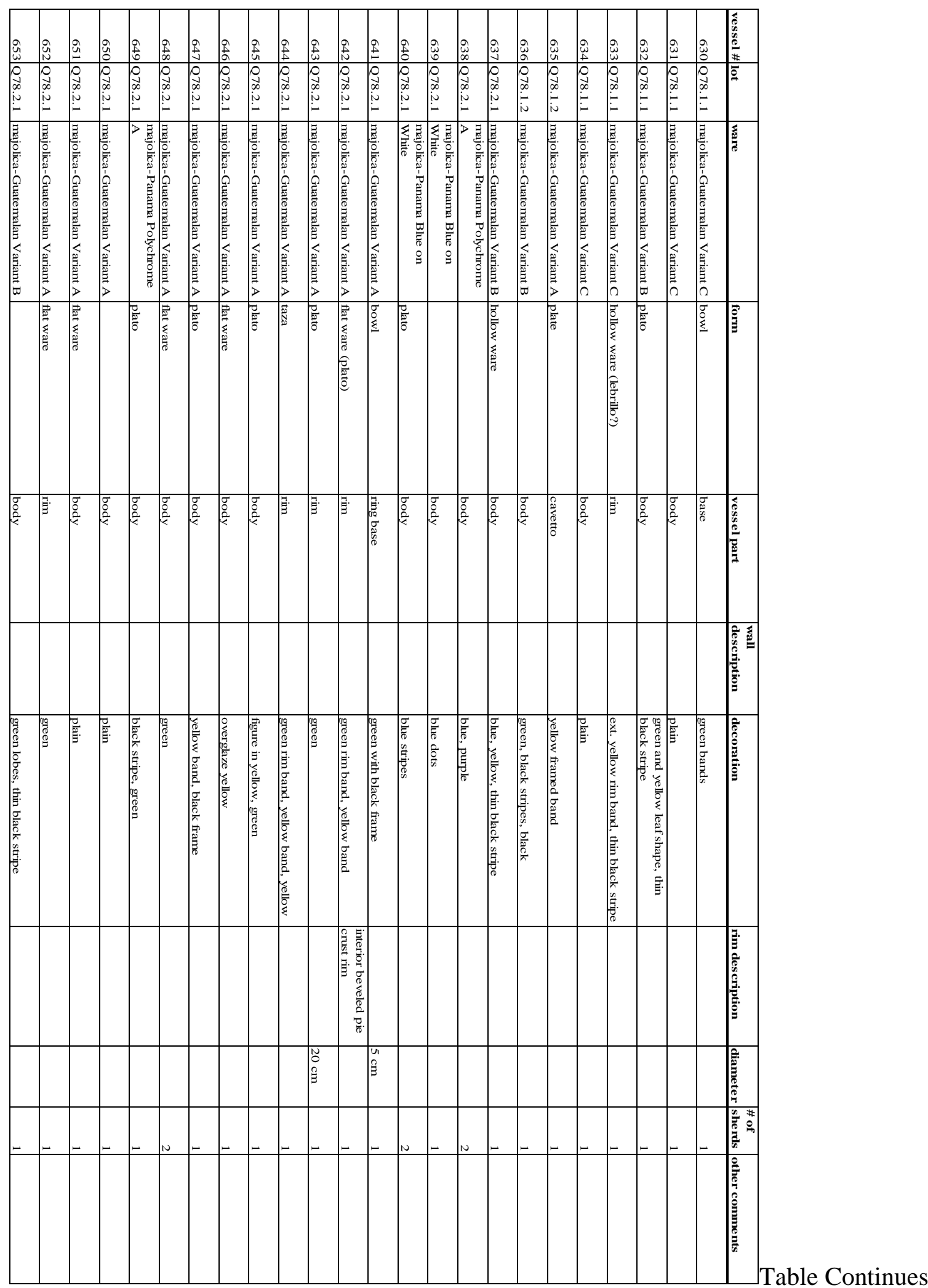


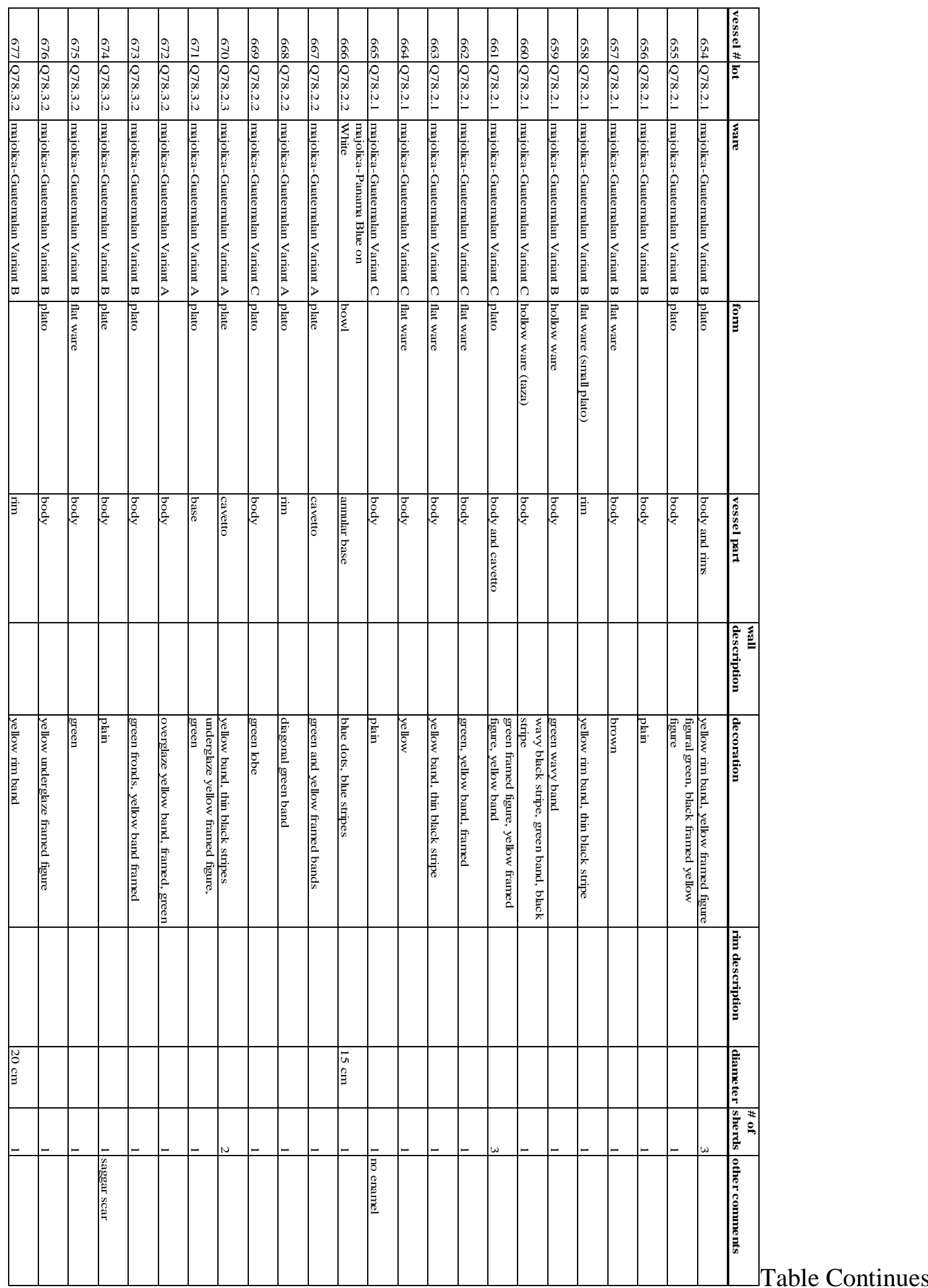



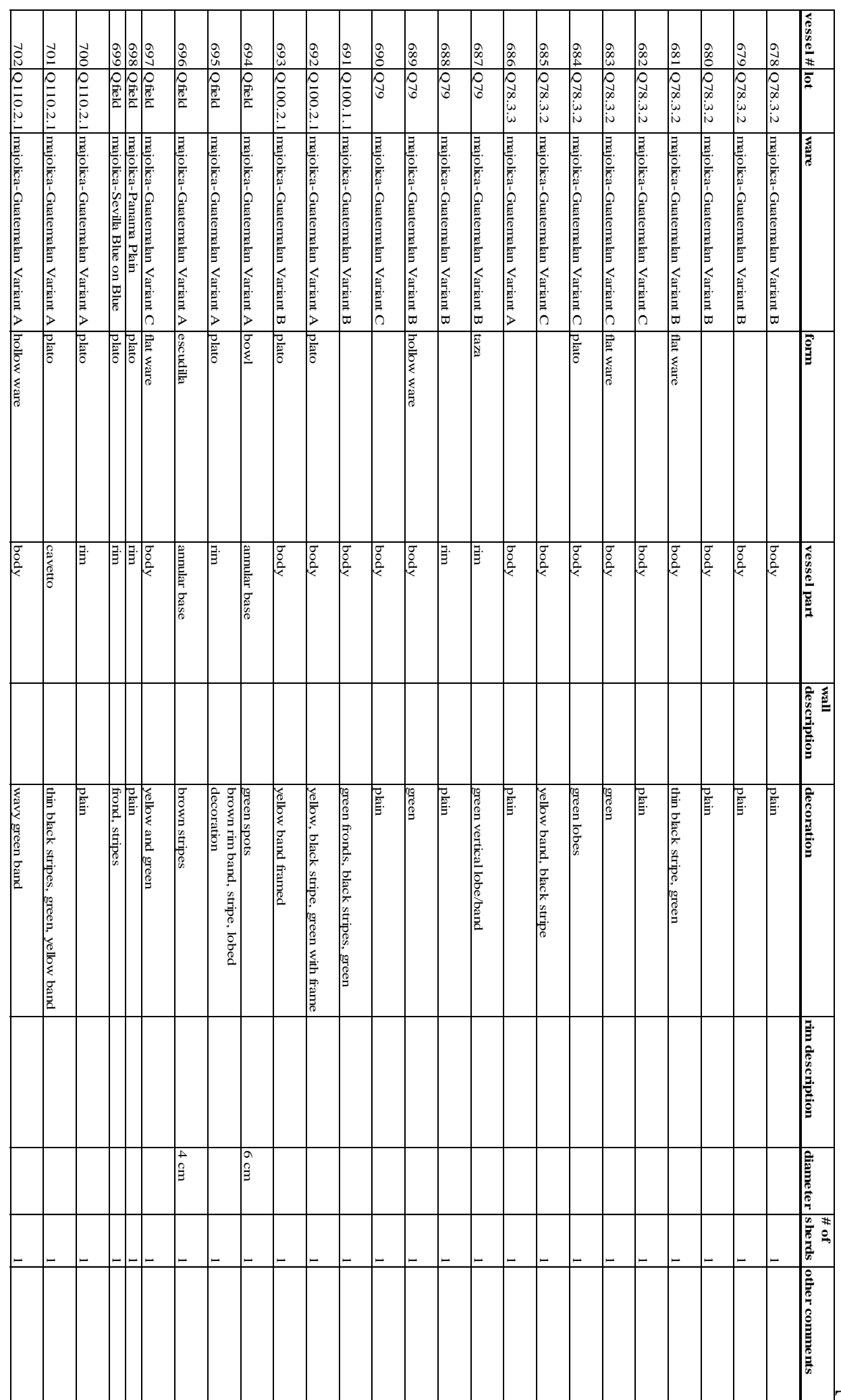

Table Continues 

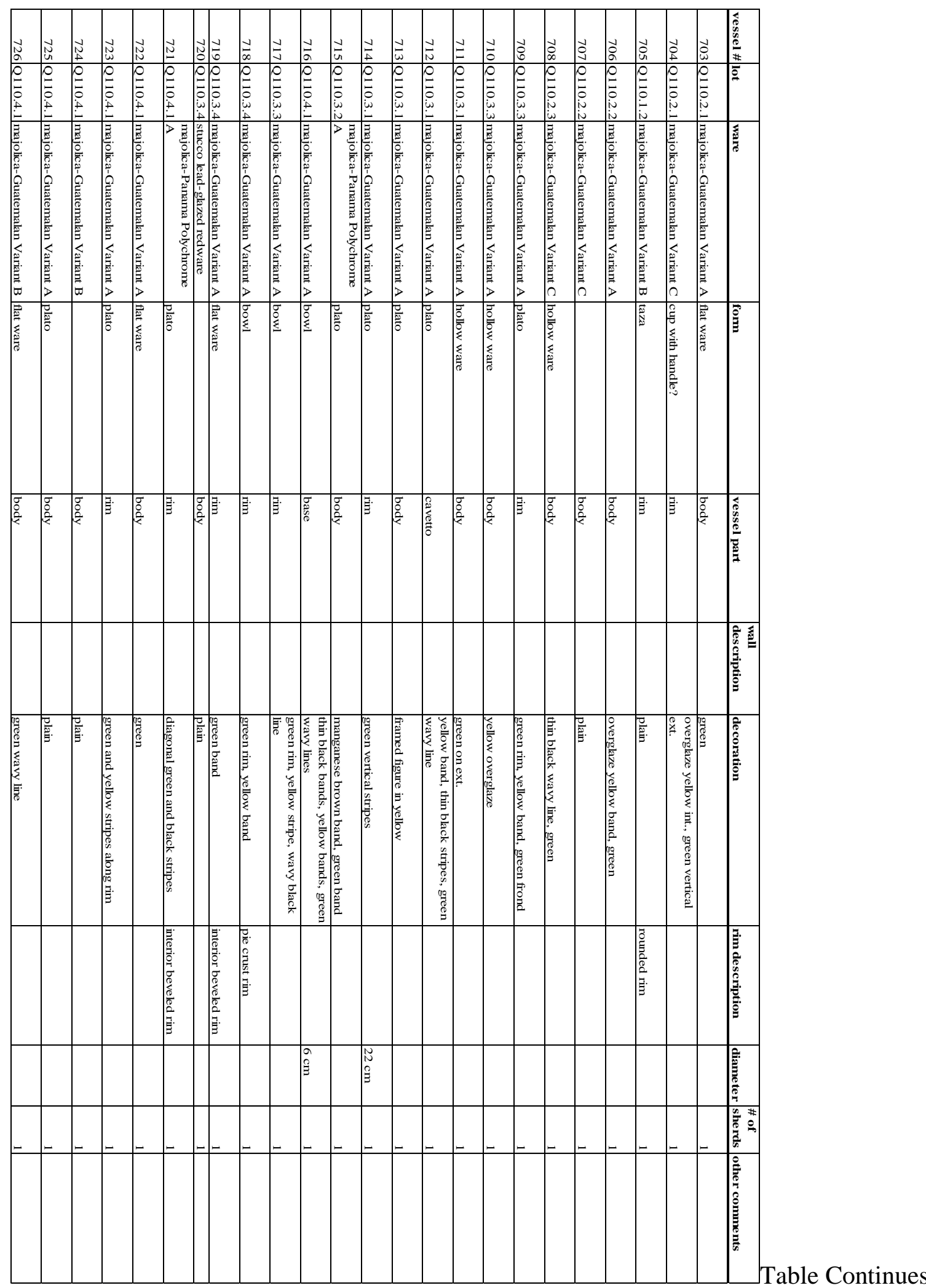


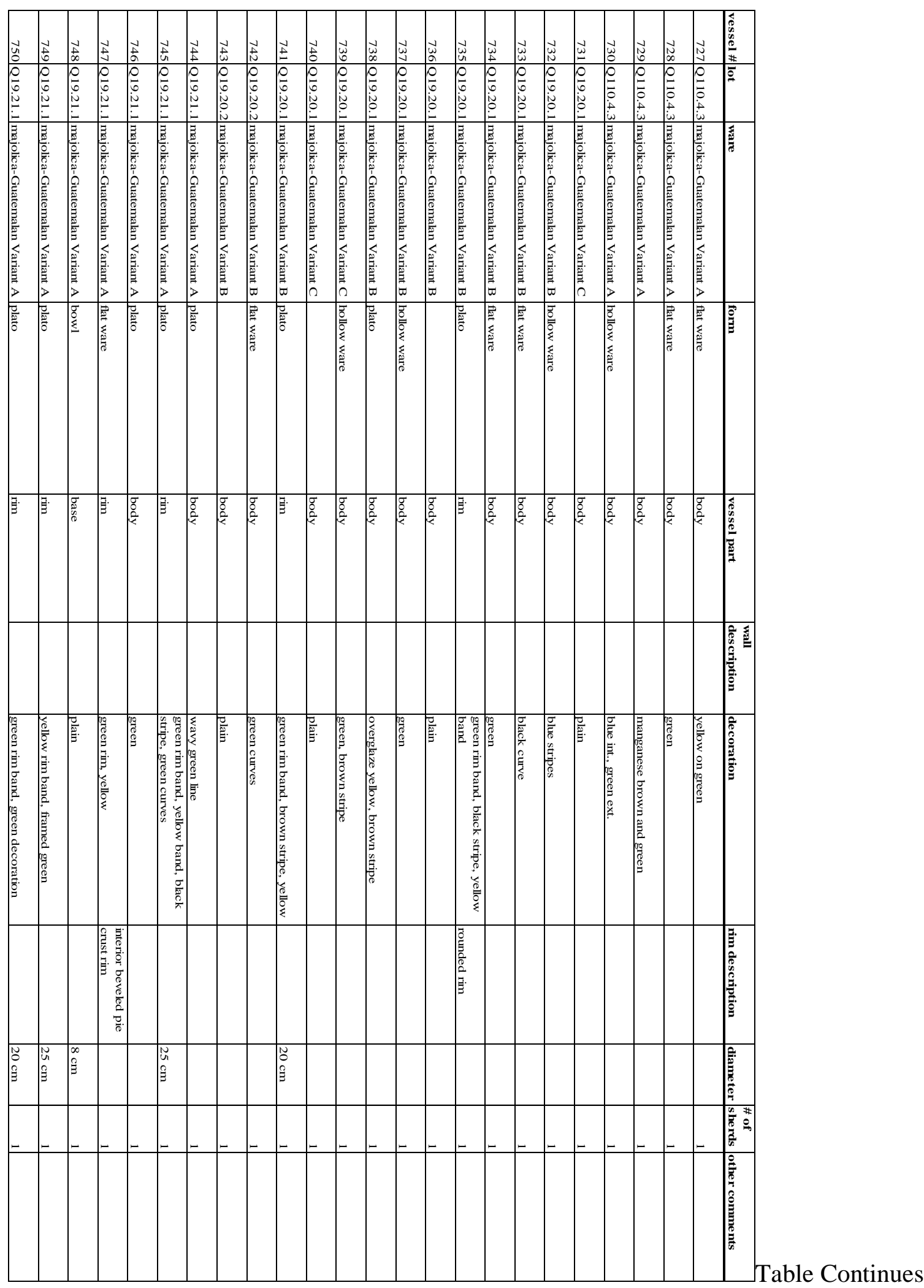




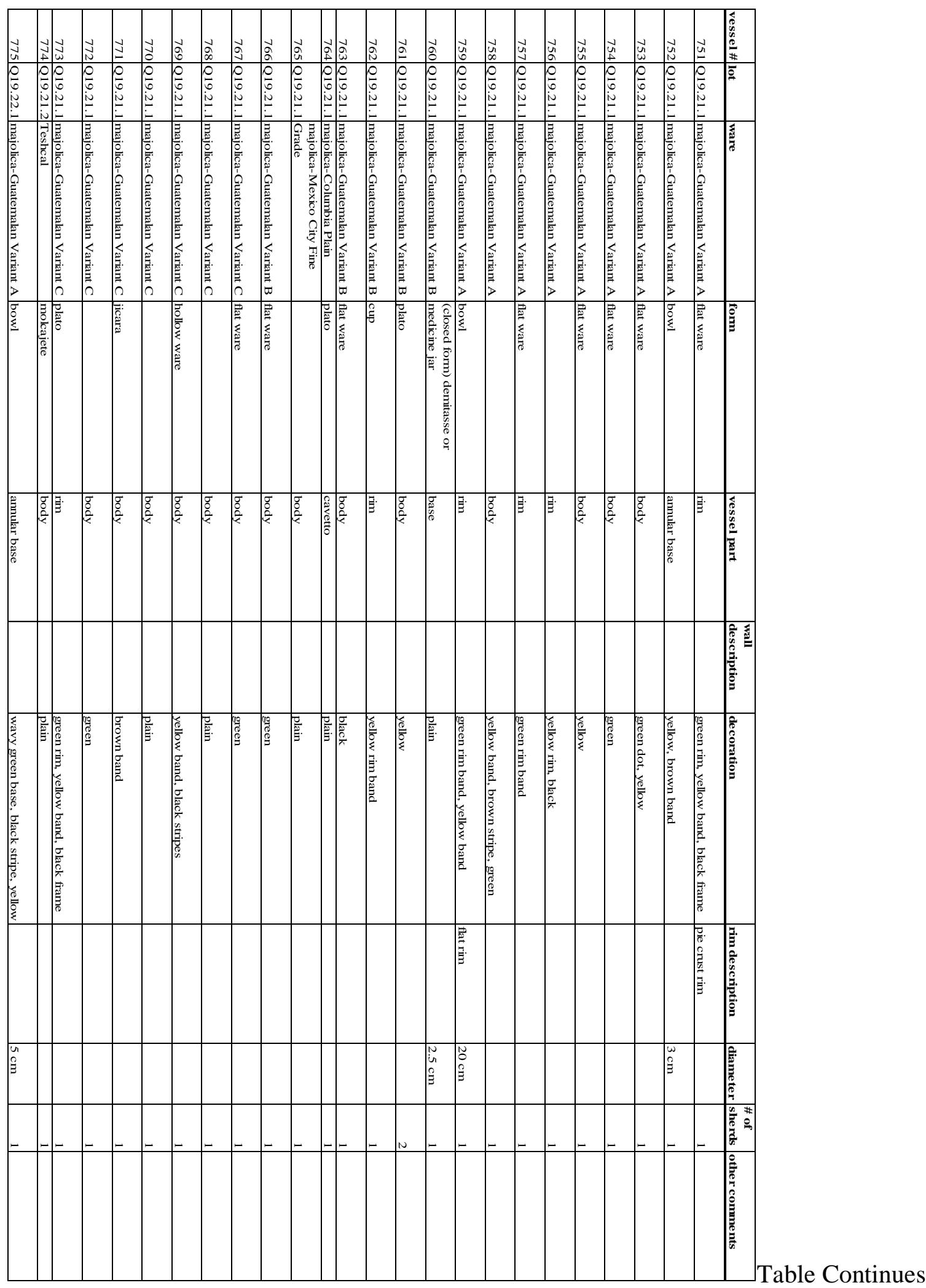




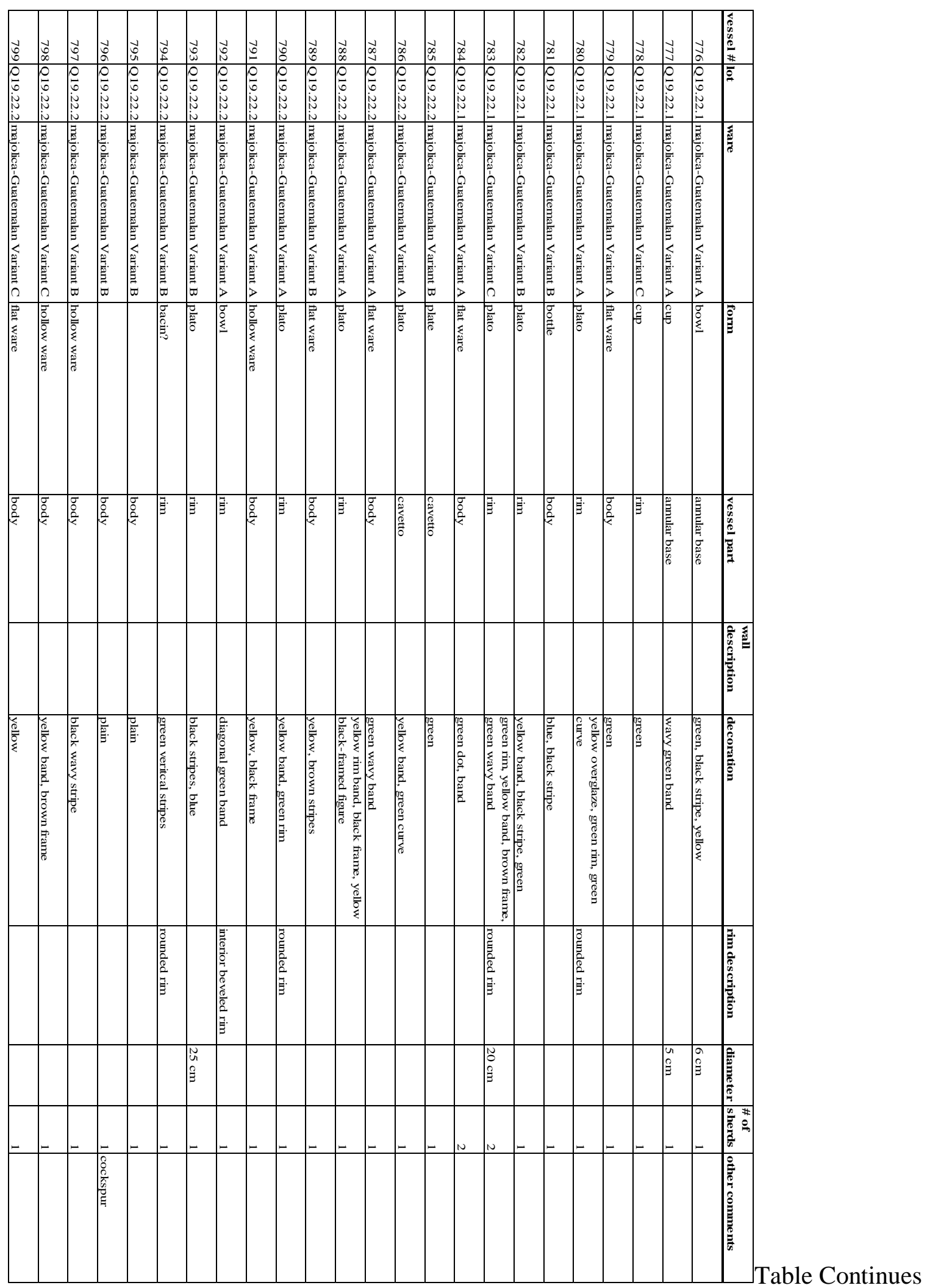




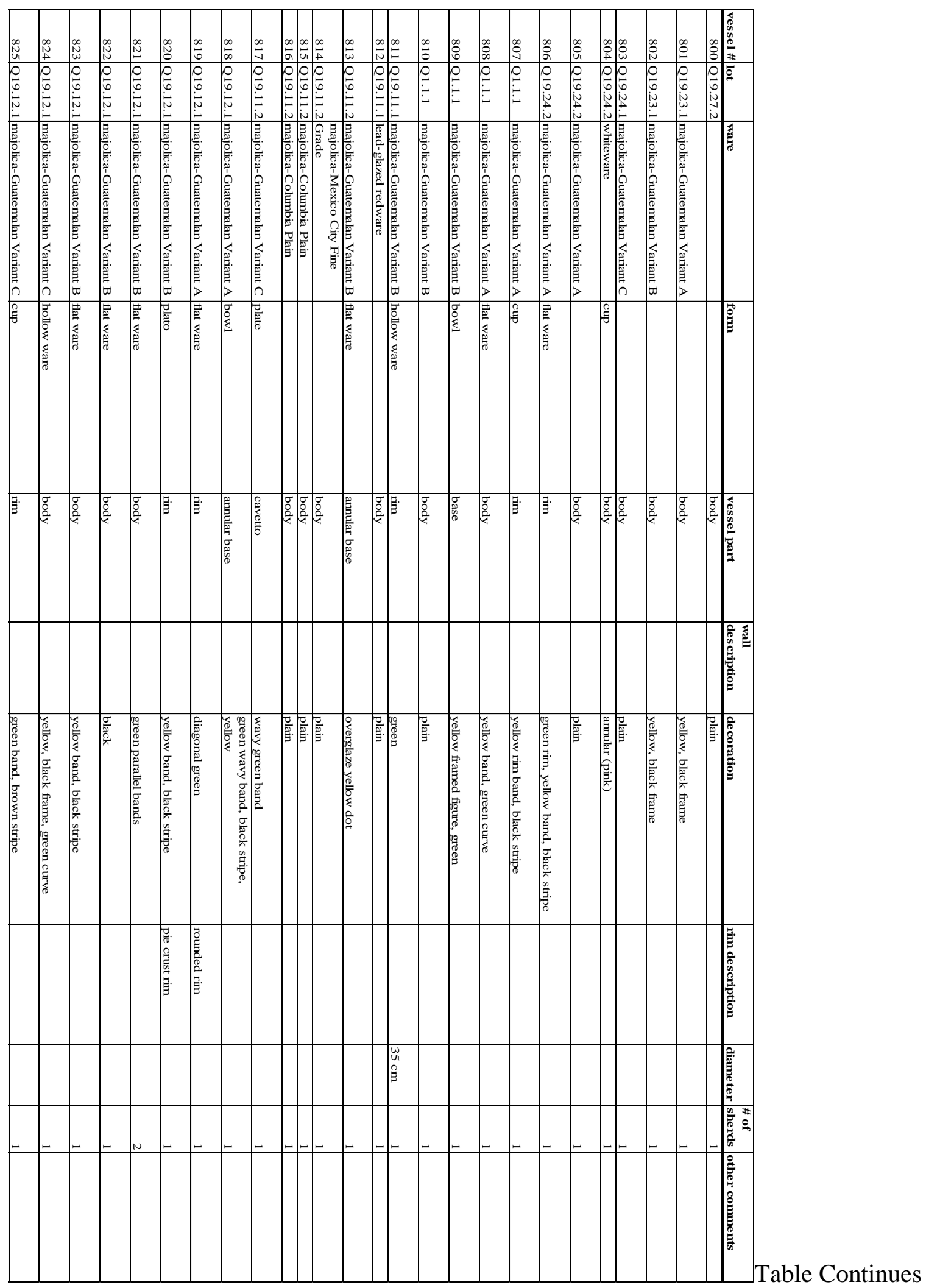



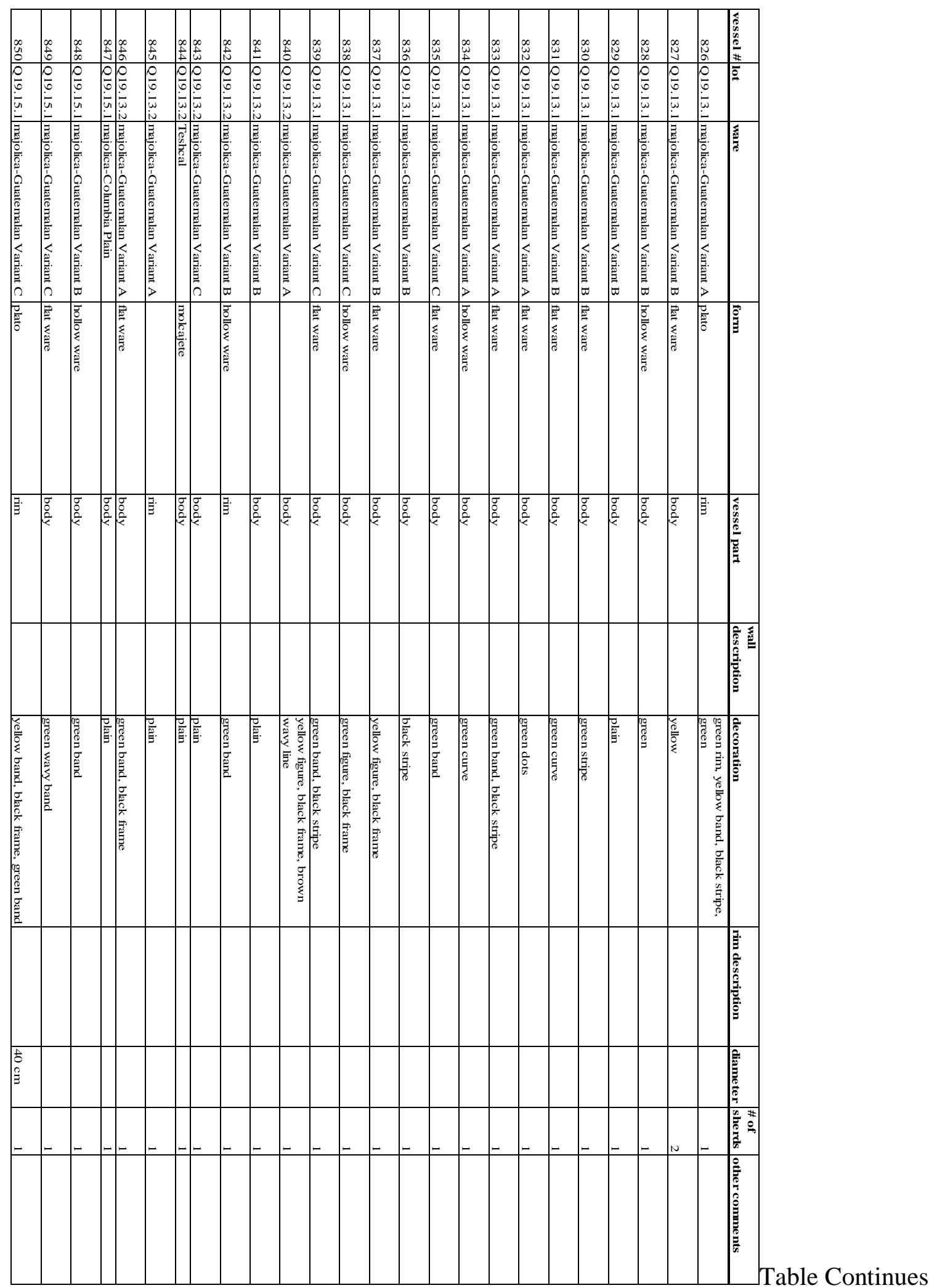


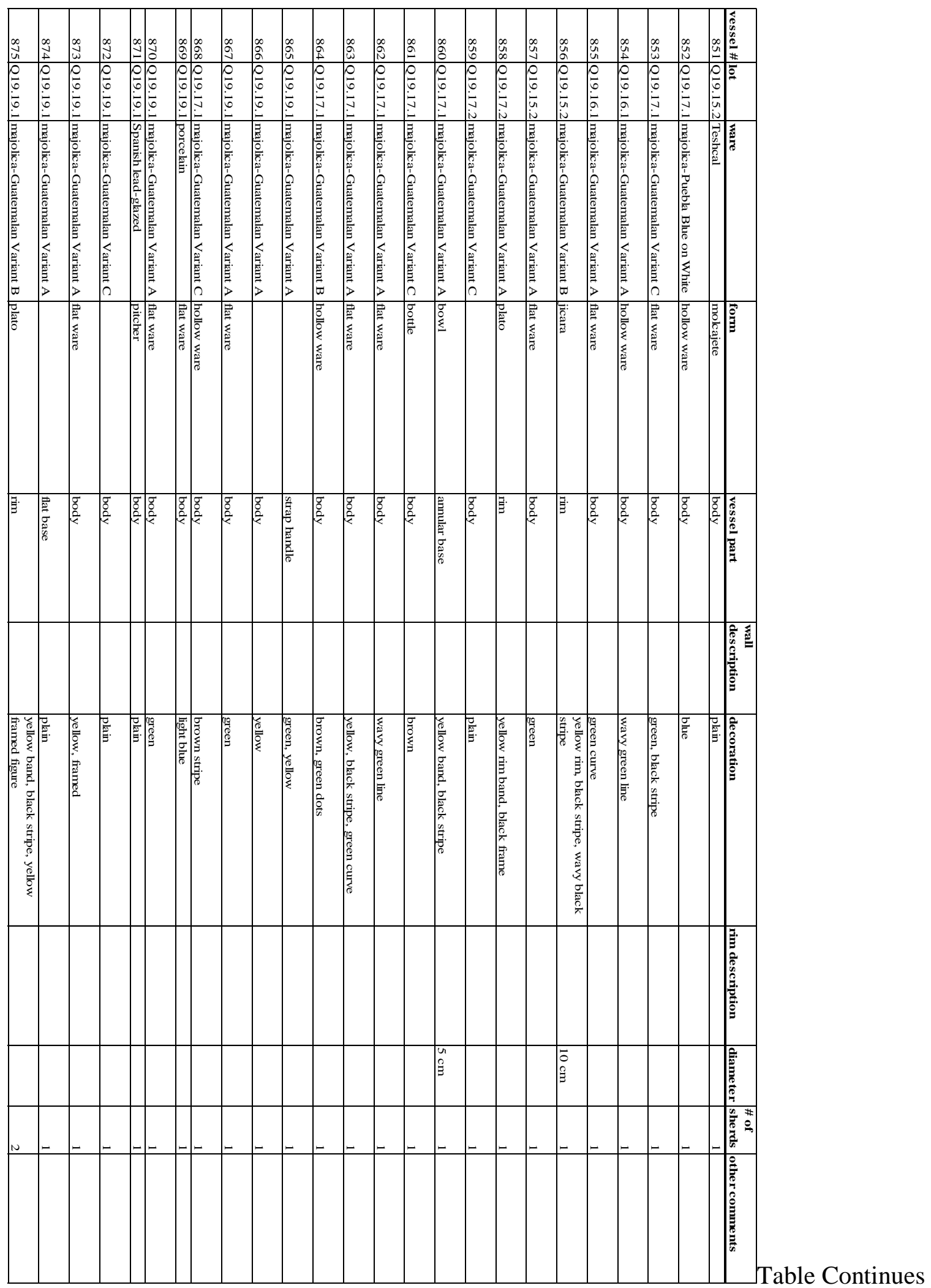



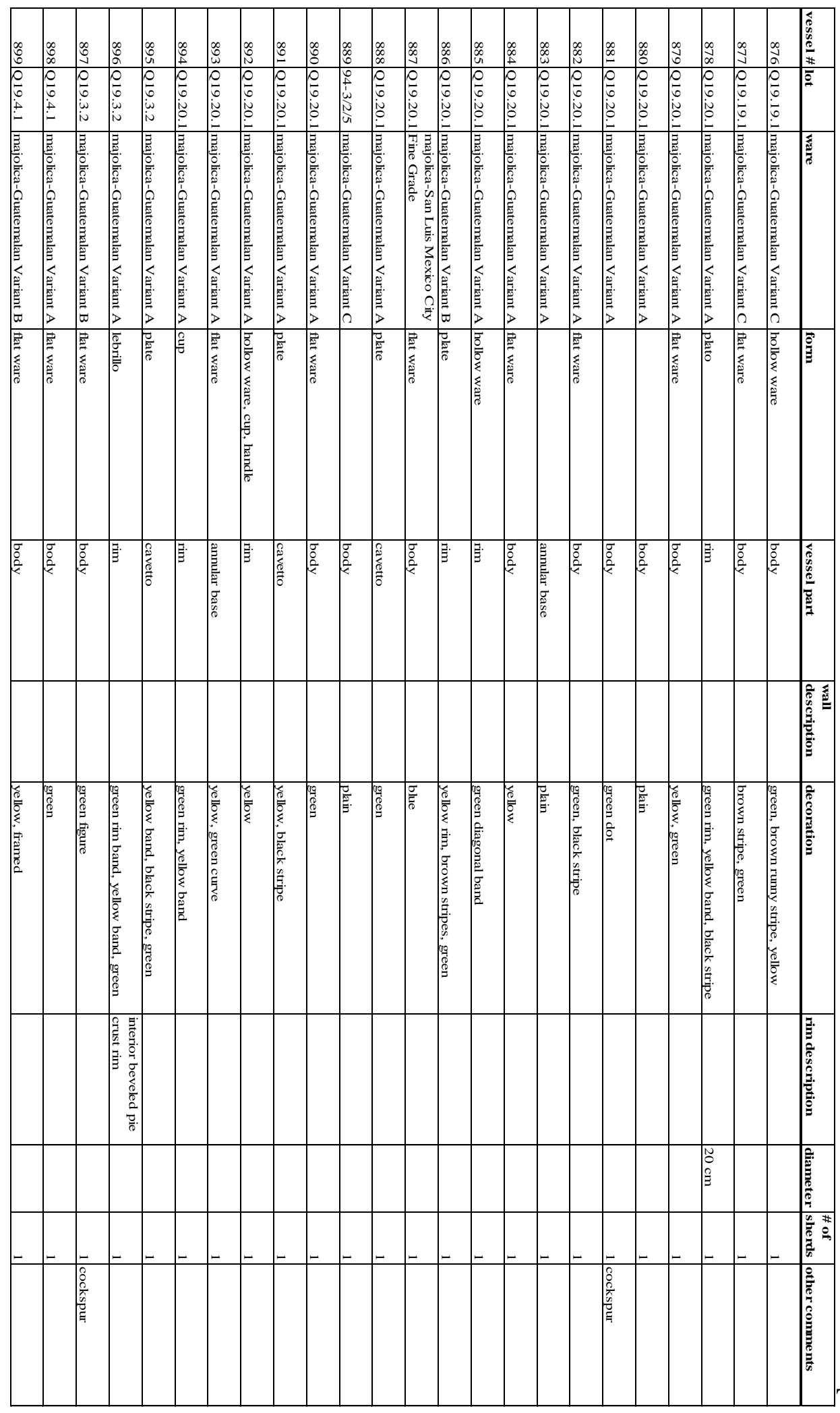

Table Continues 


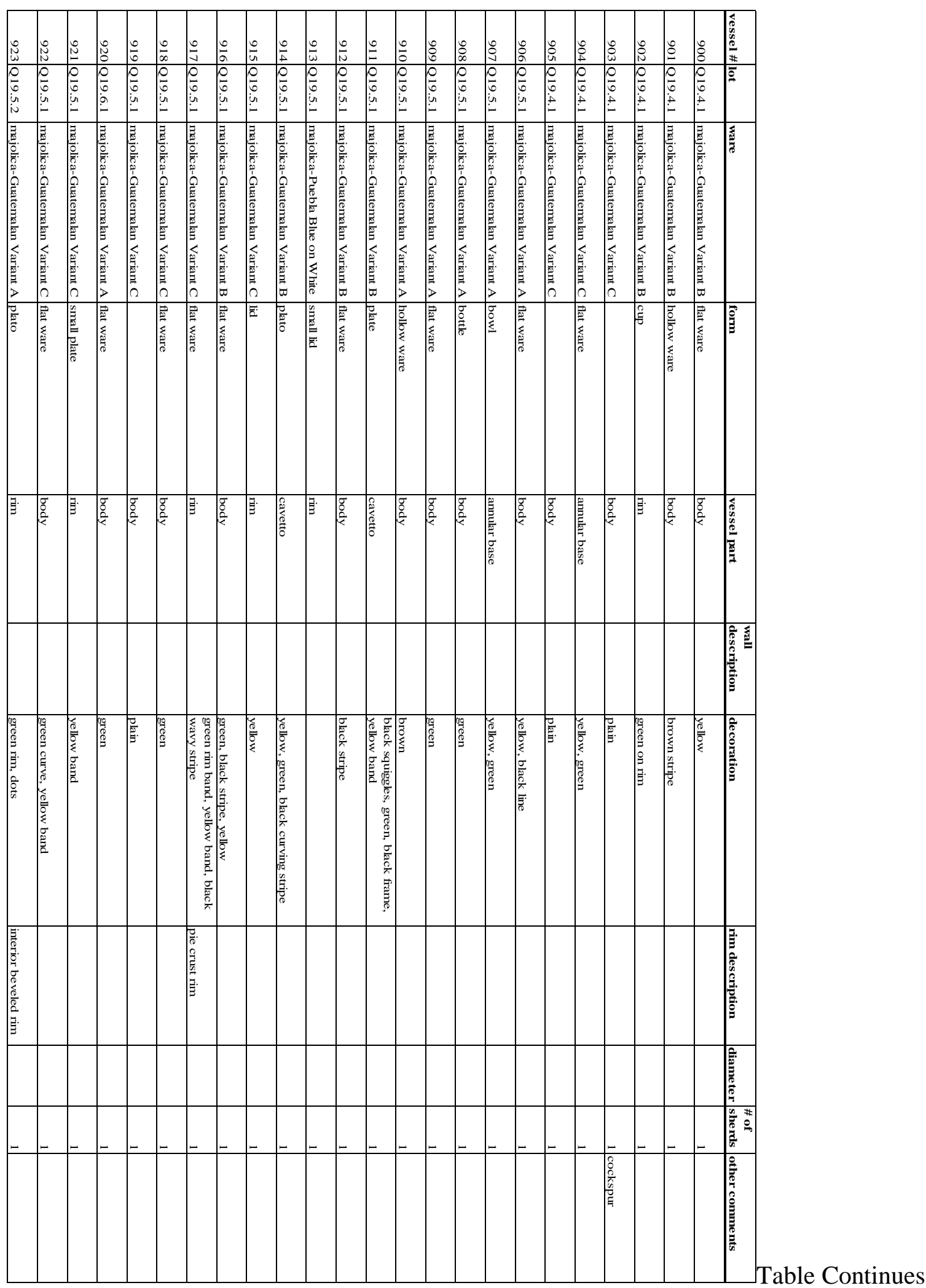




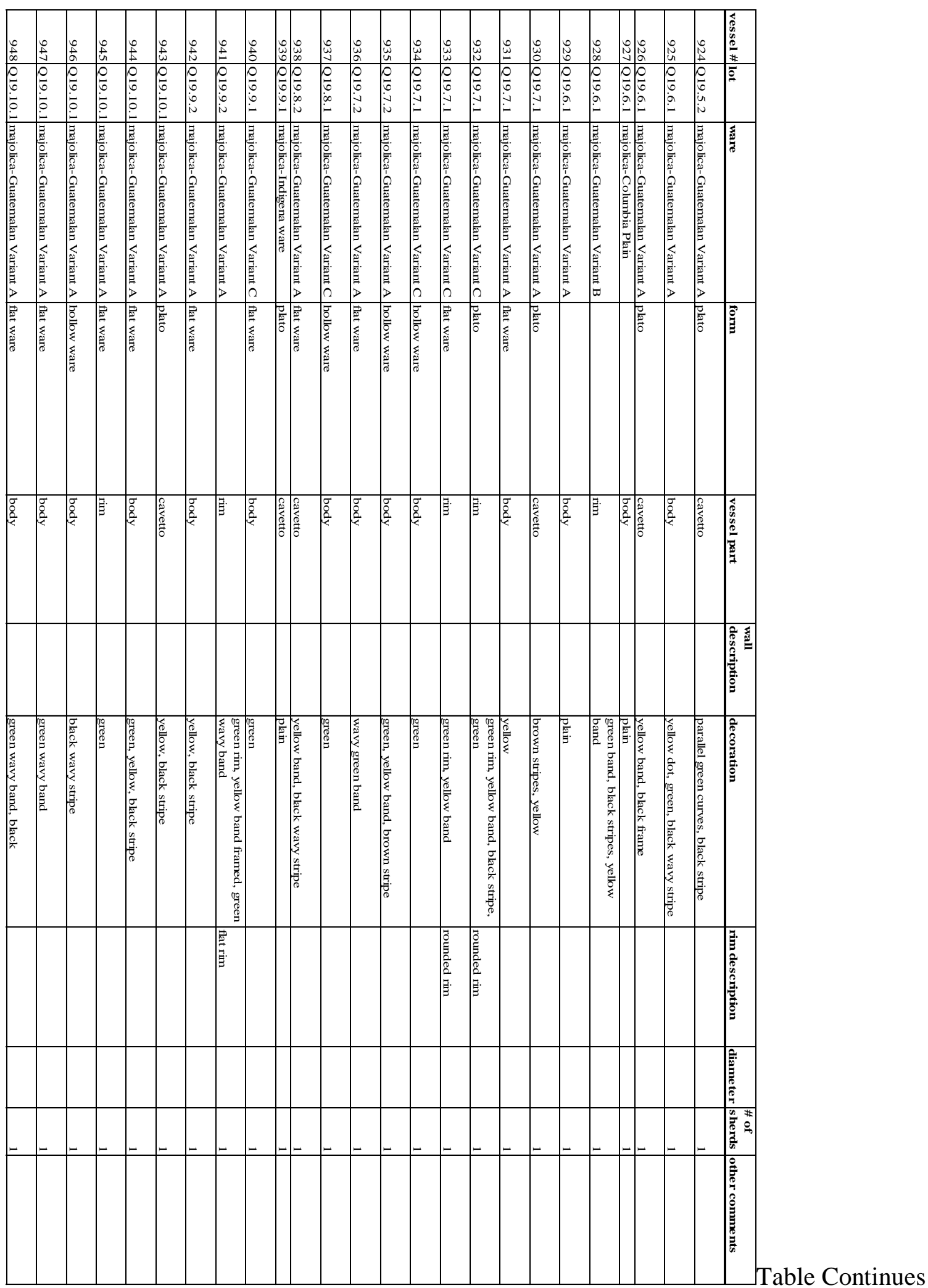




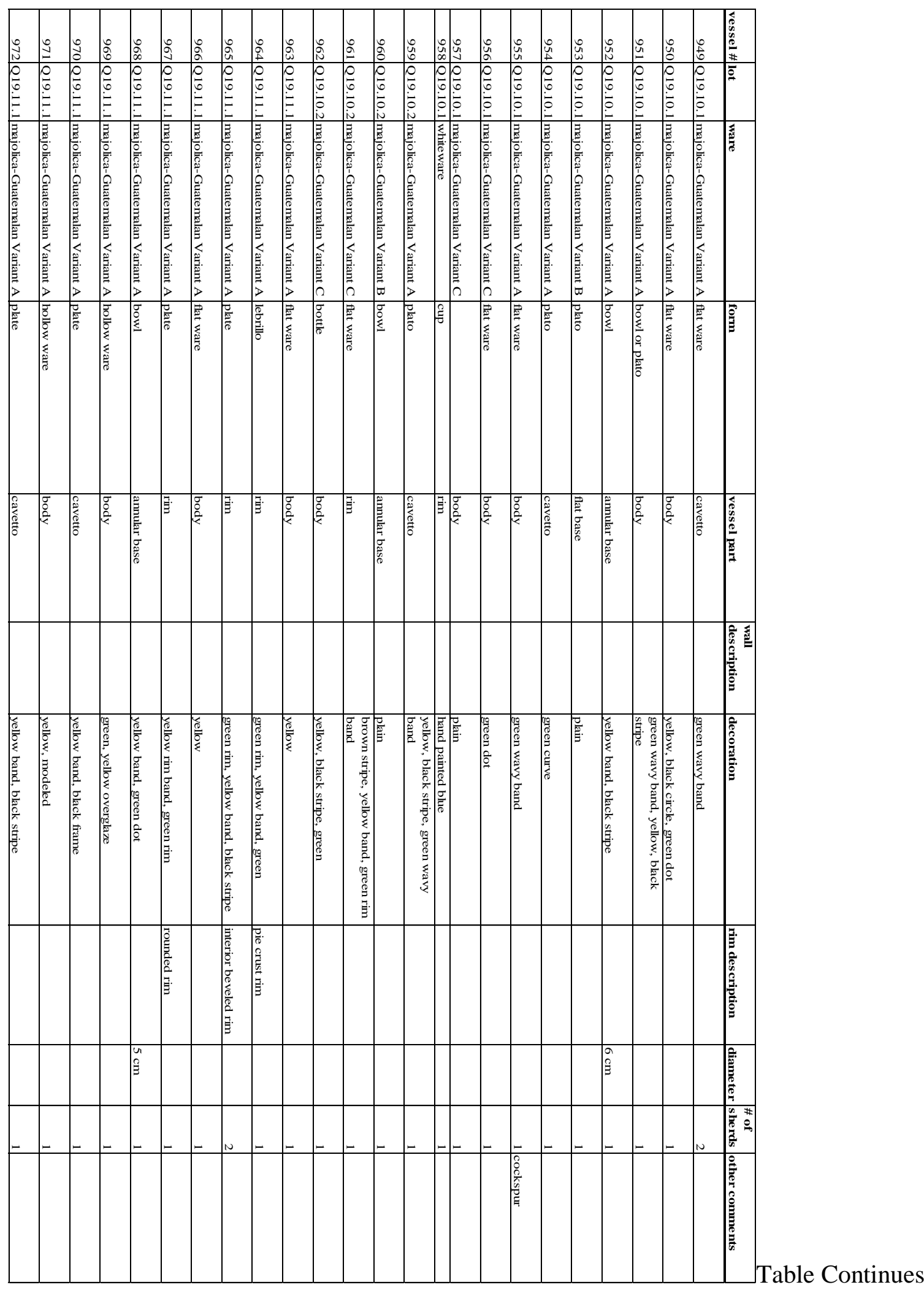




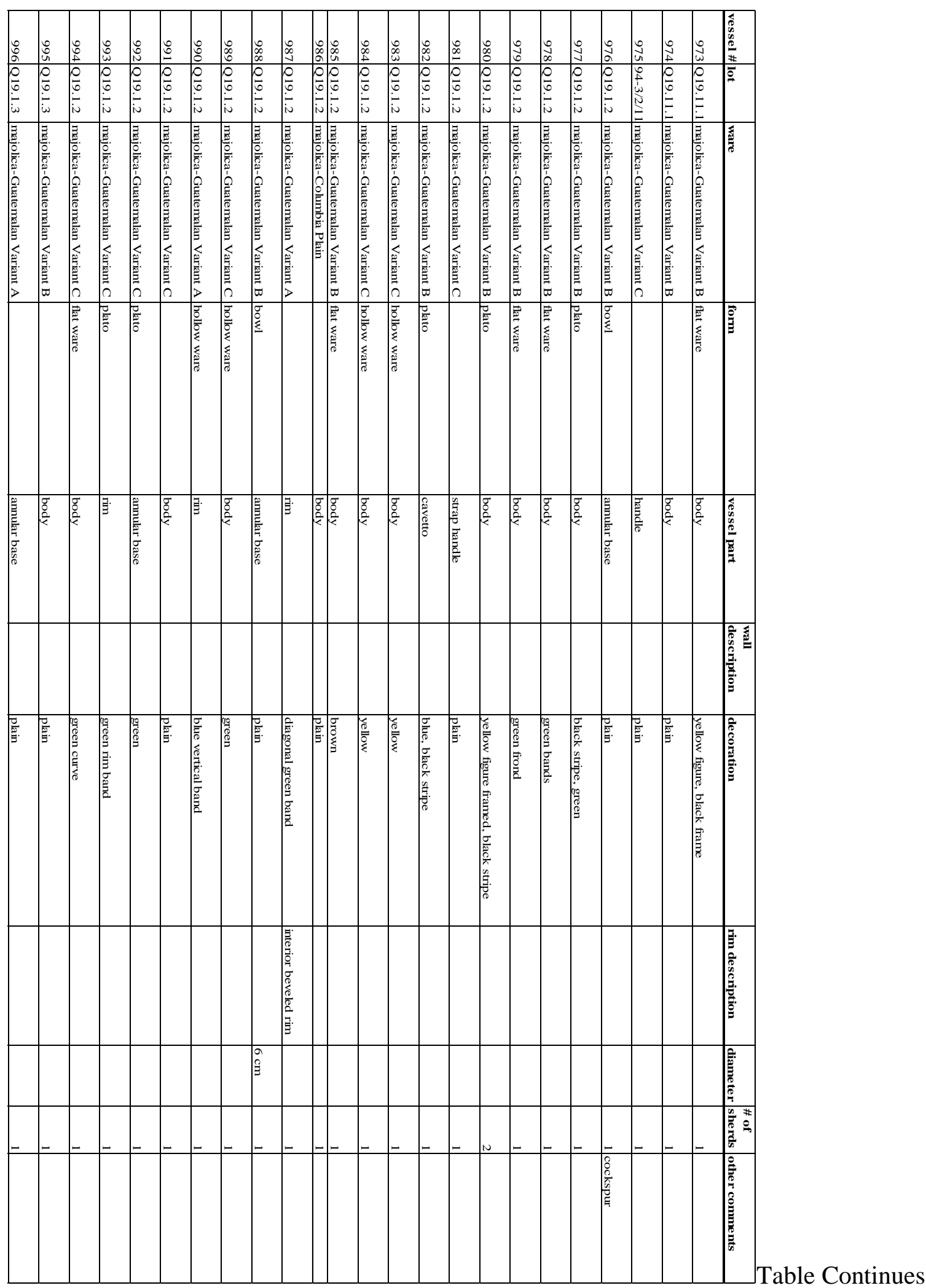




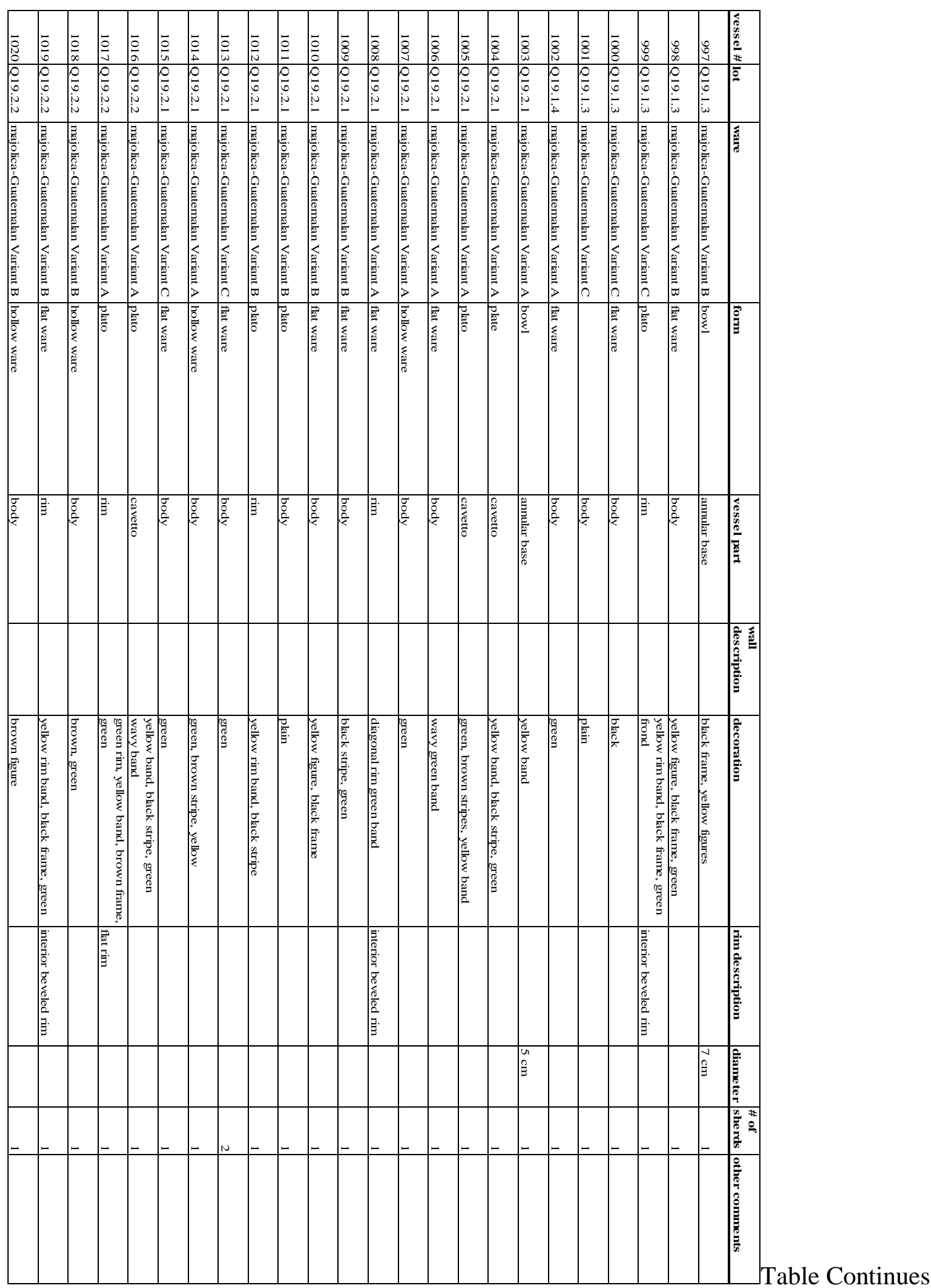



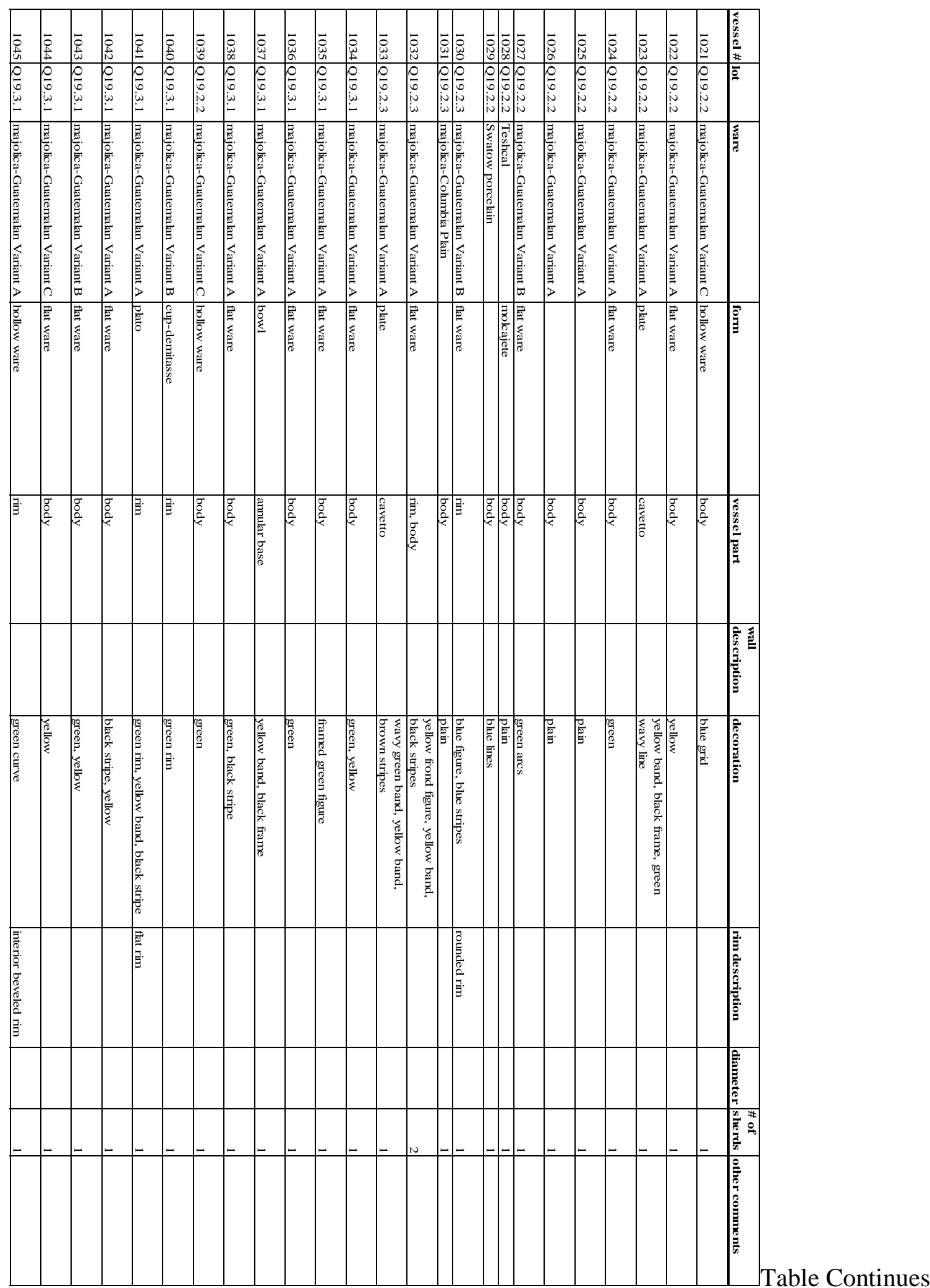


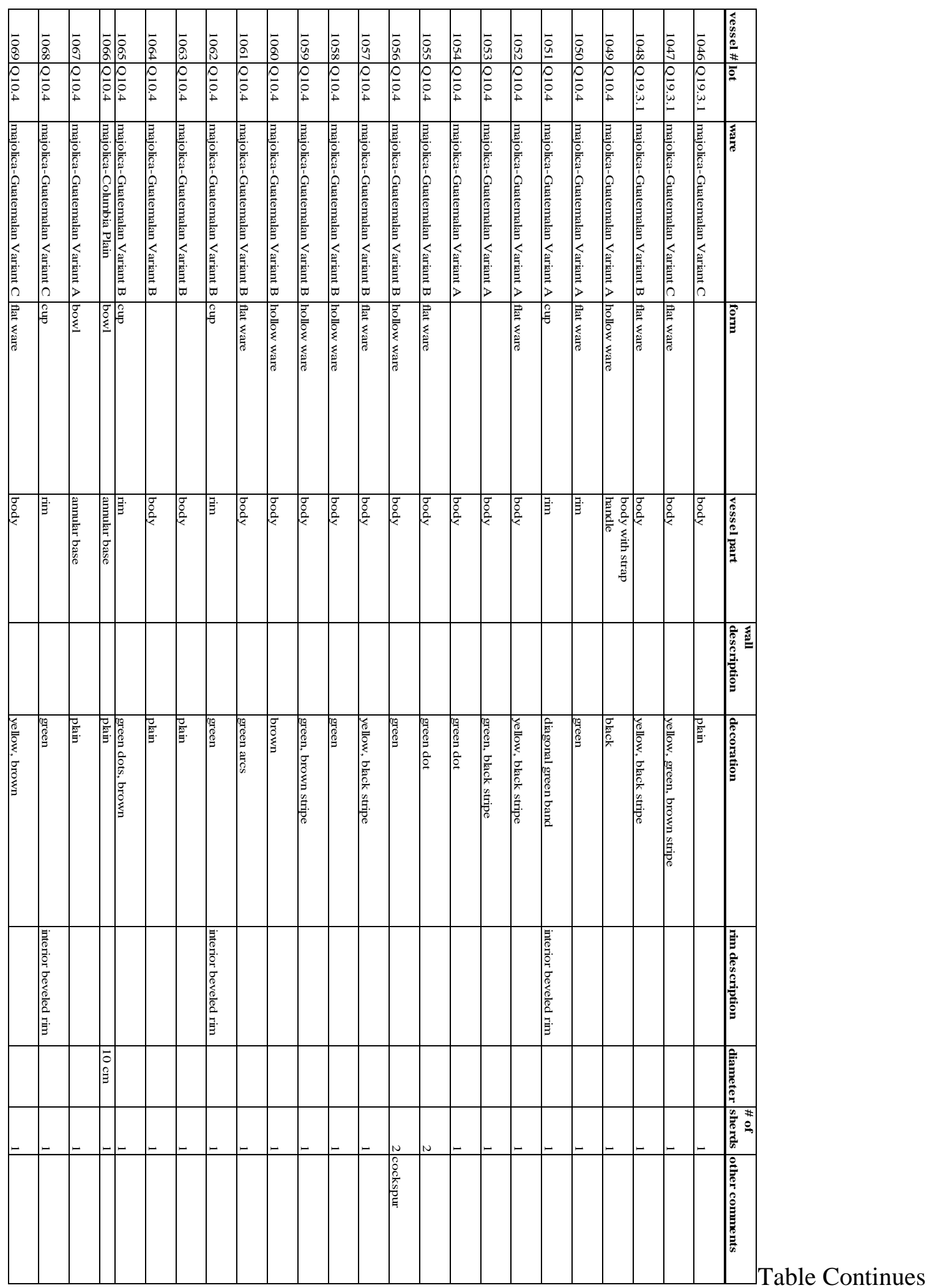




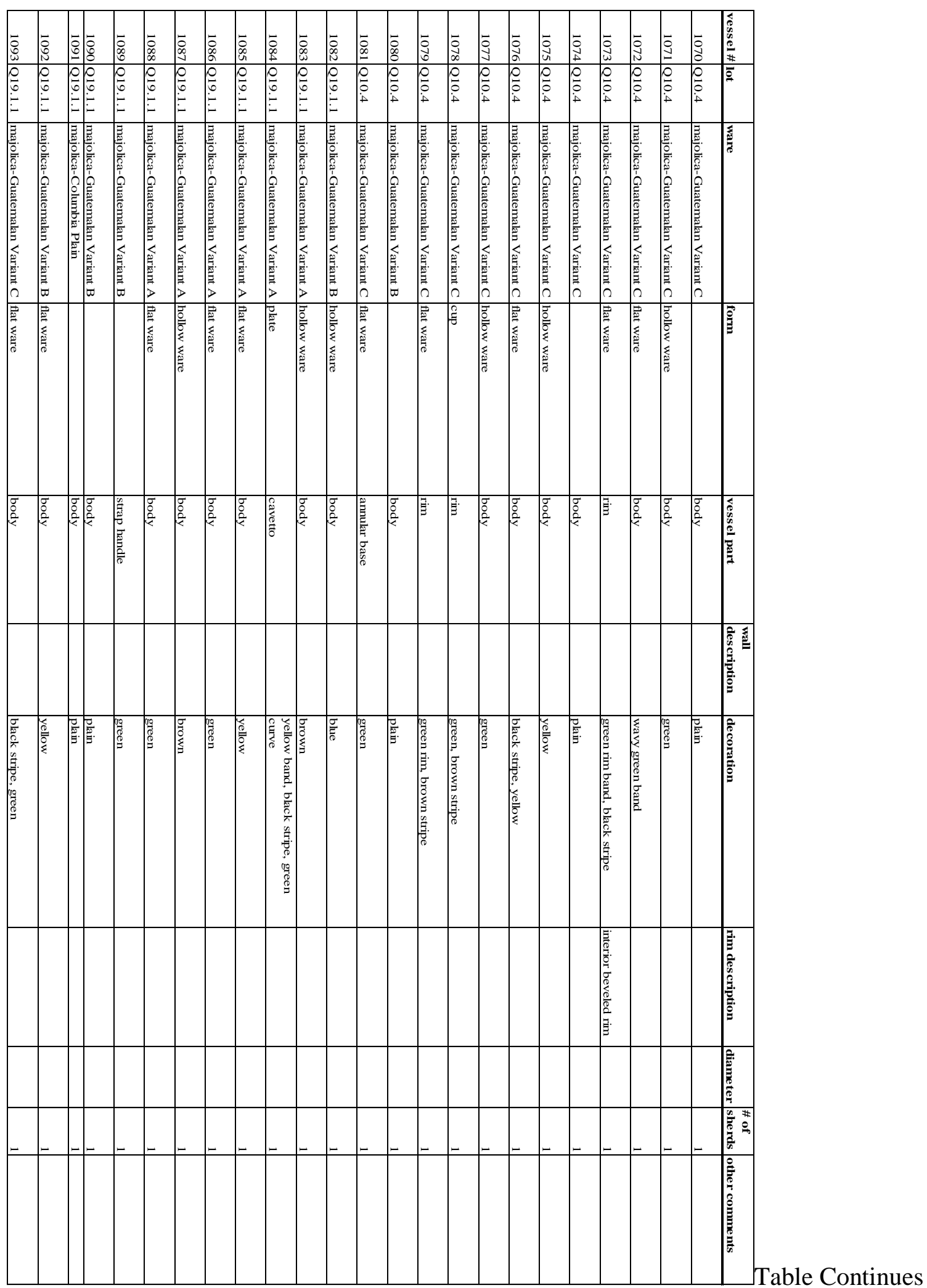




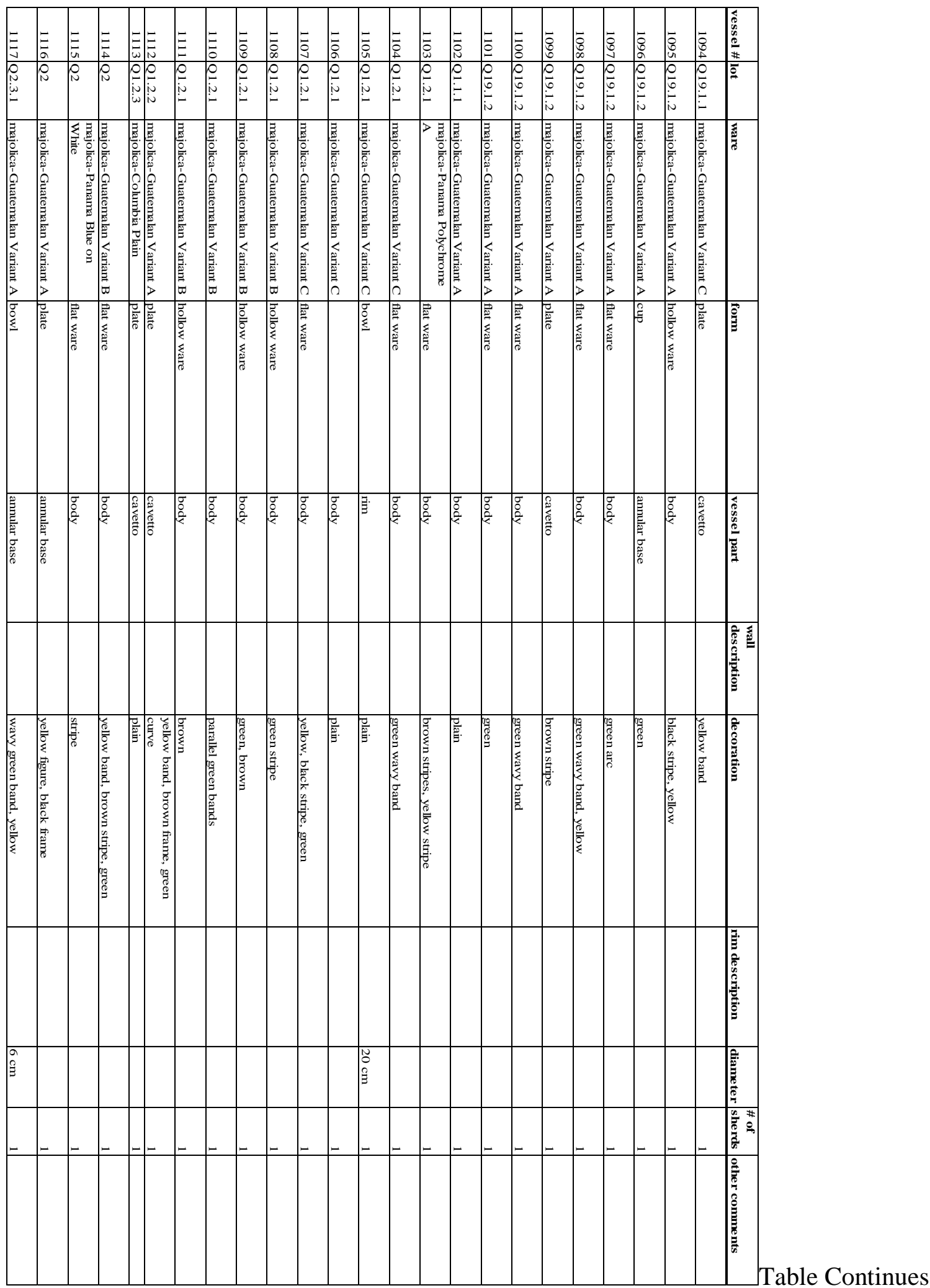




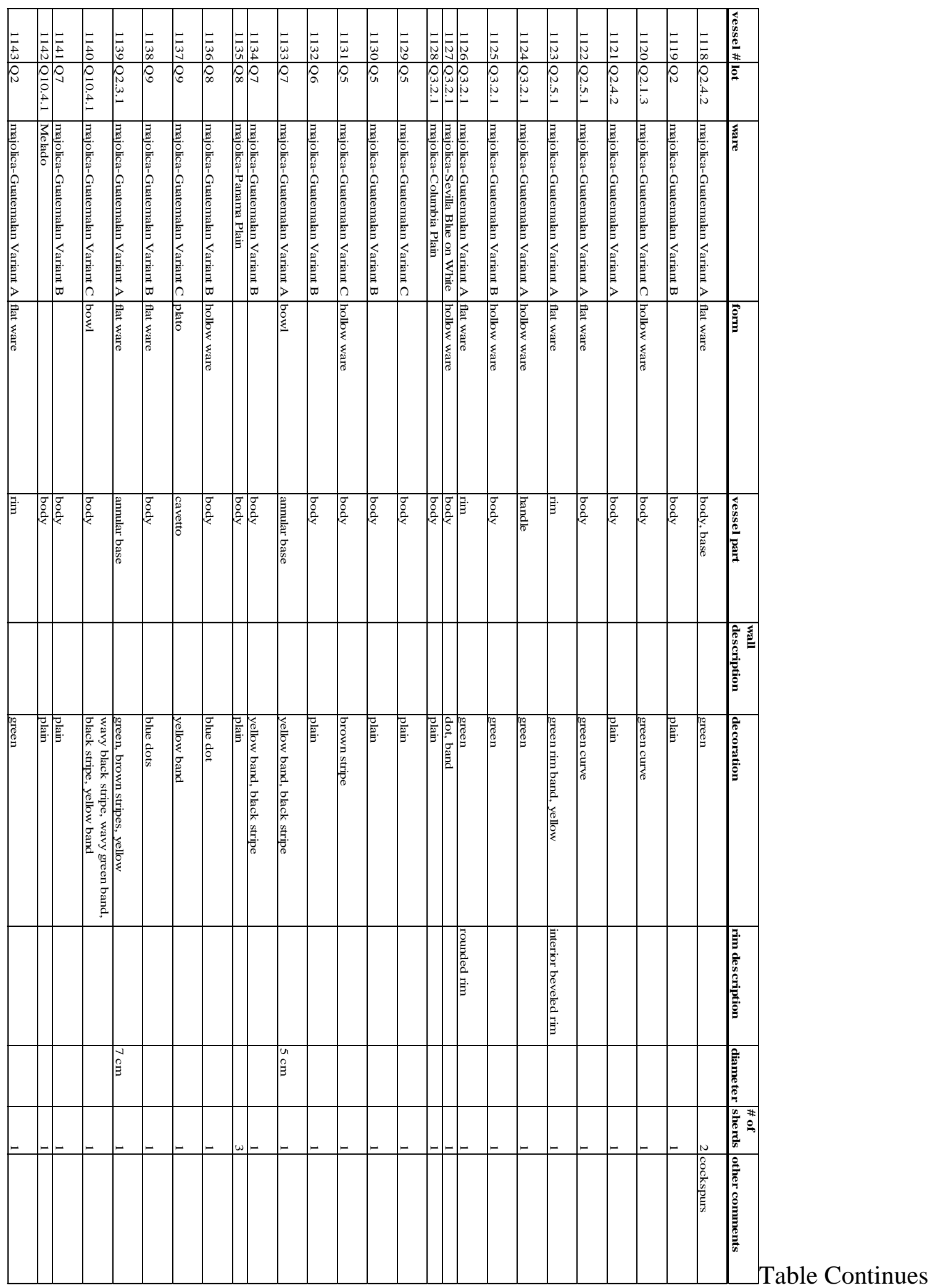




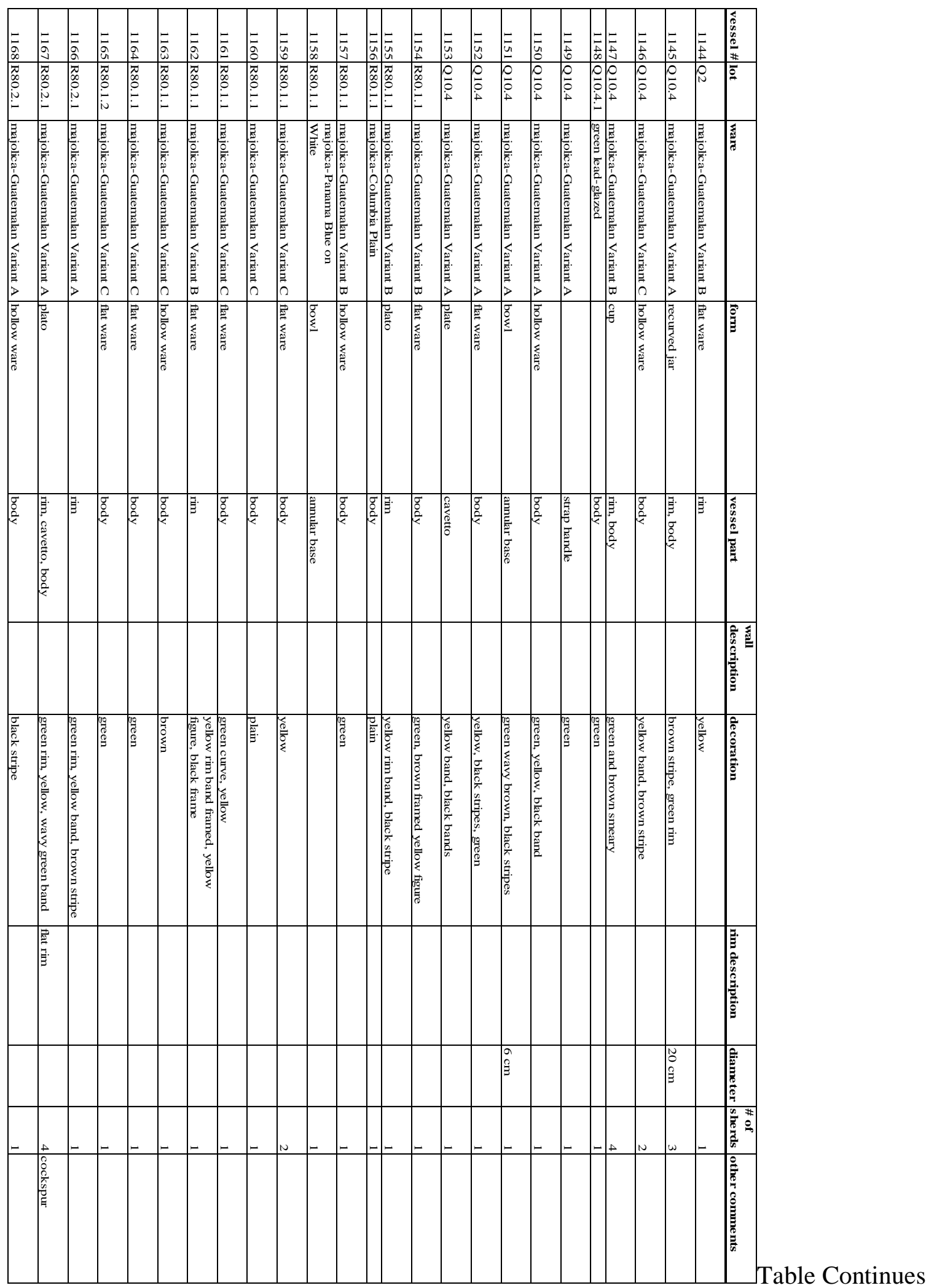




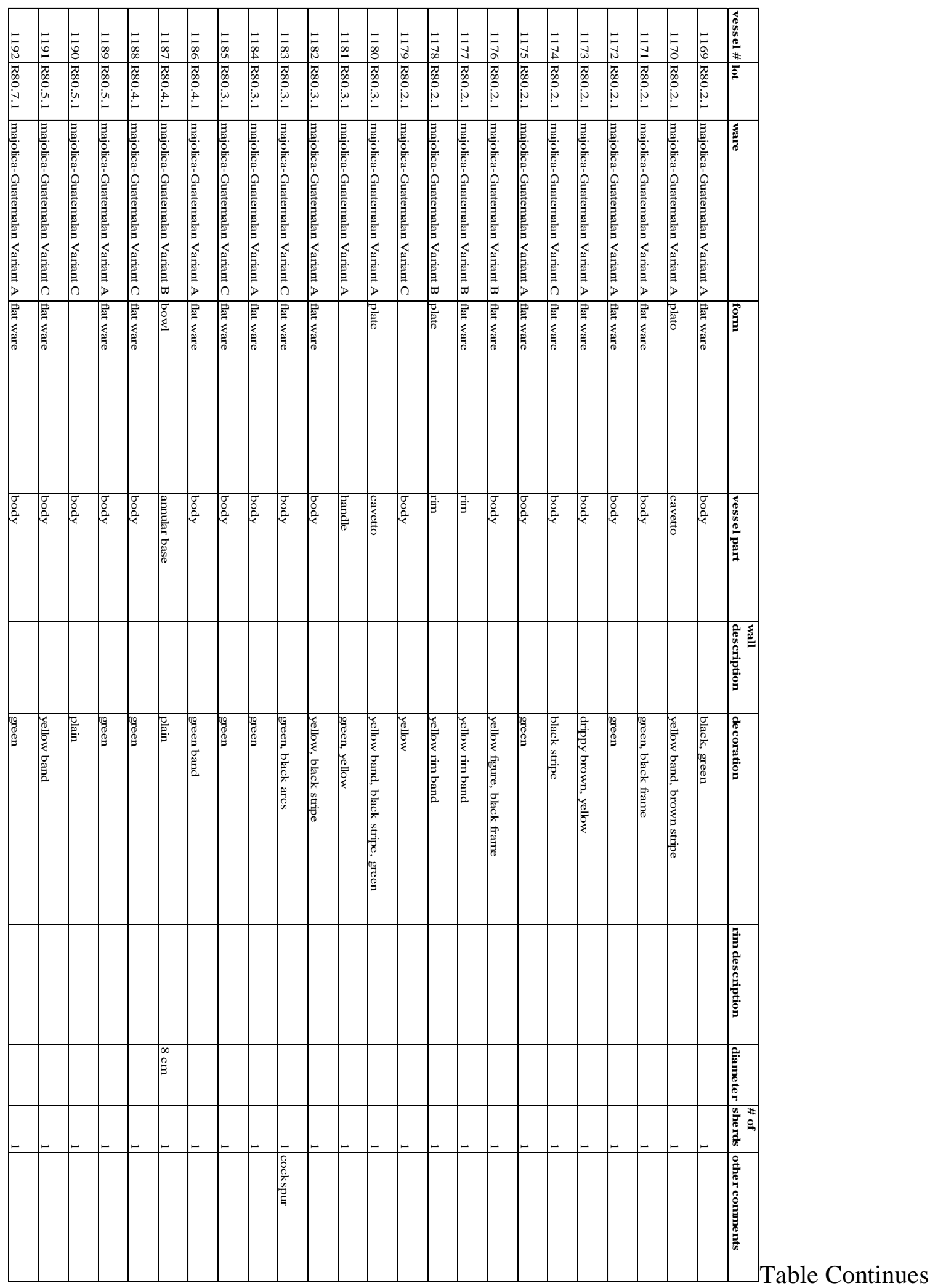




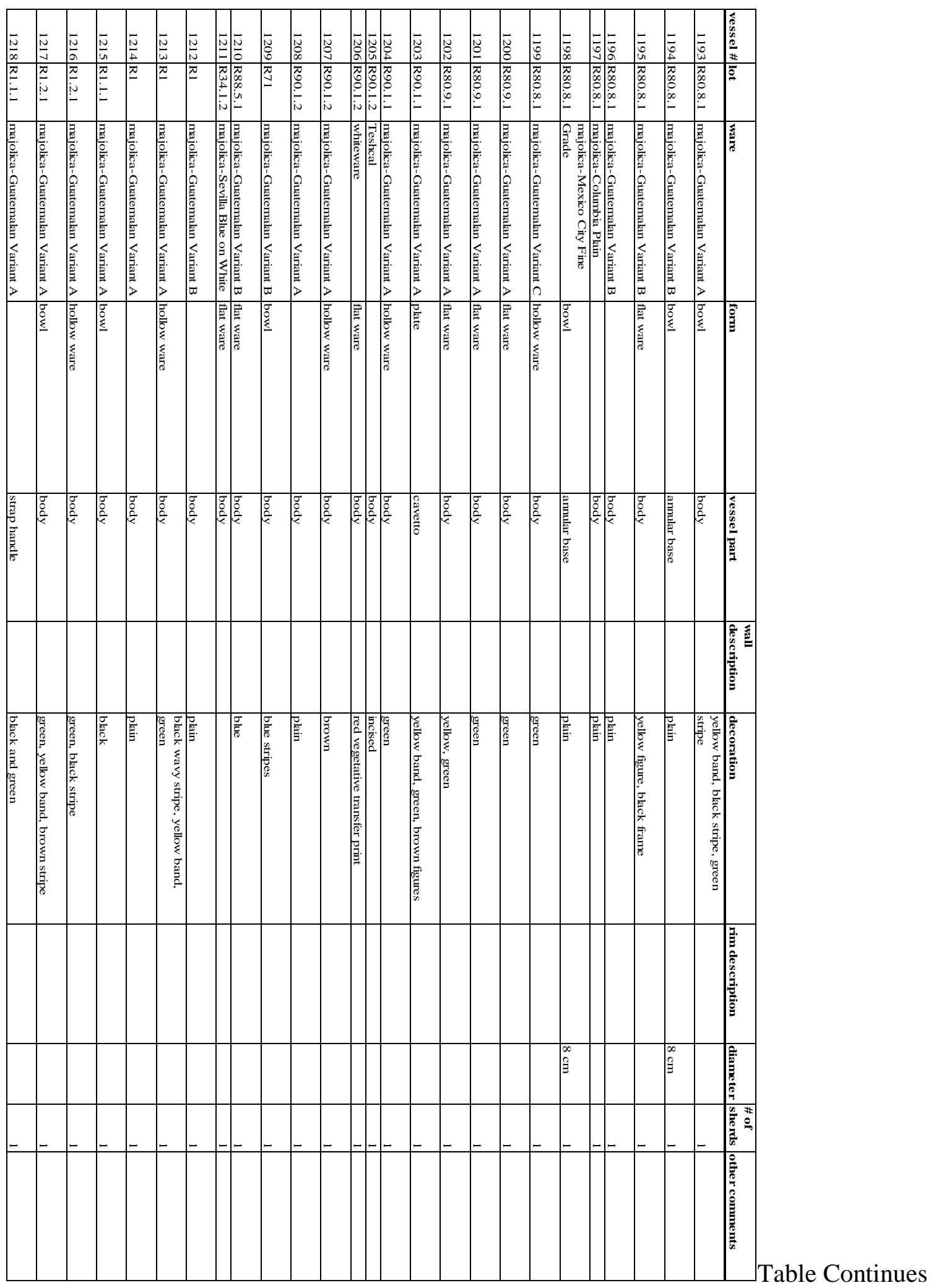




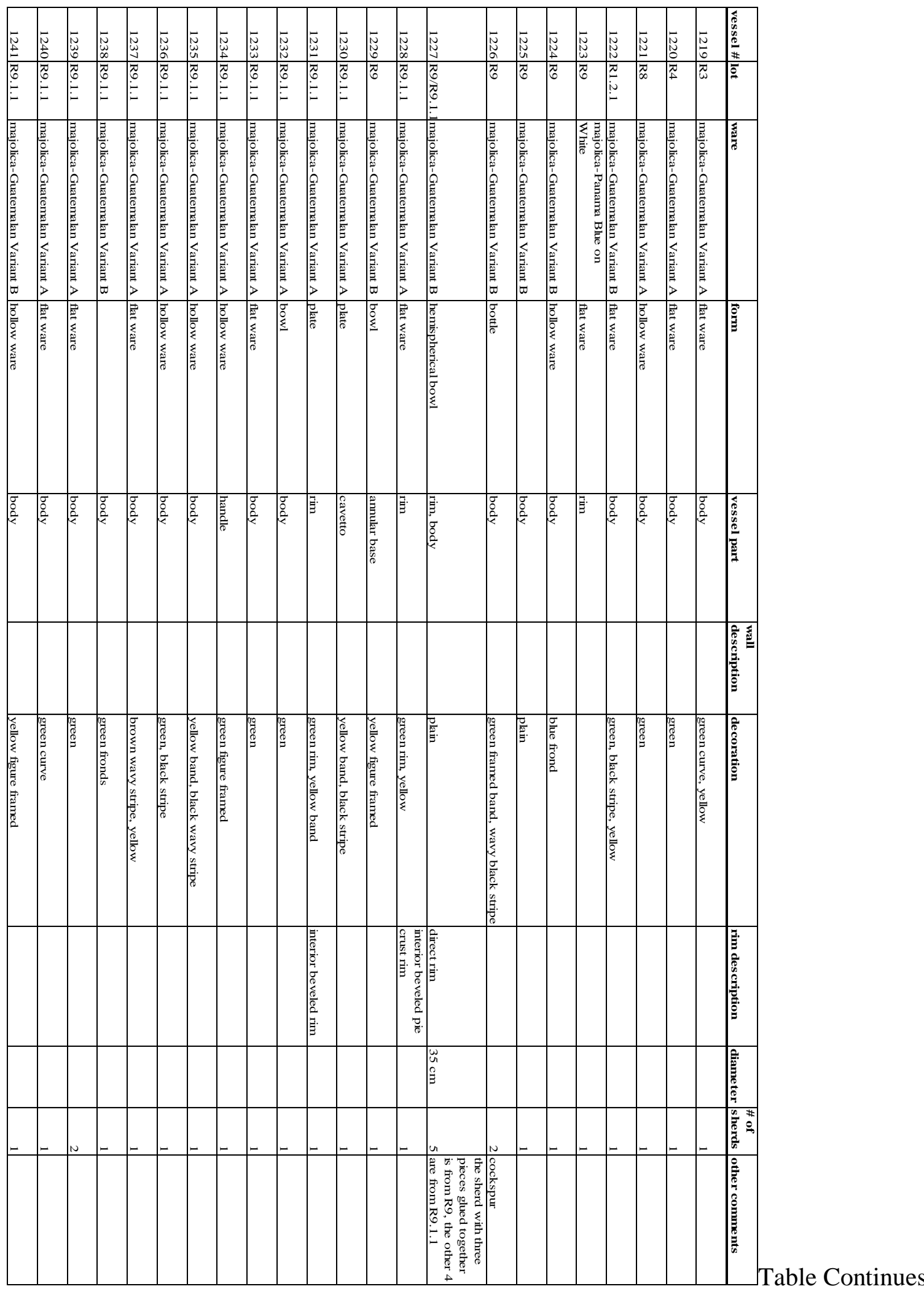




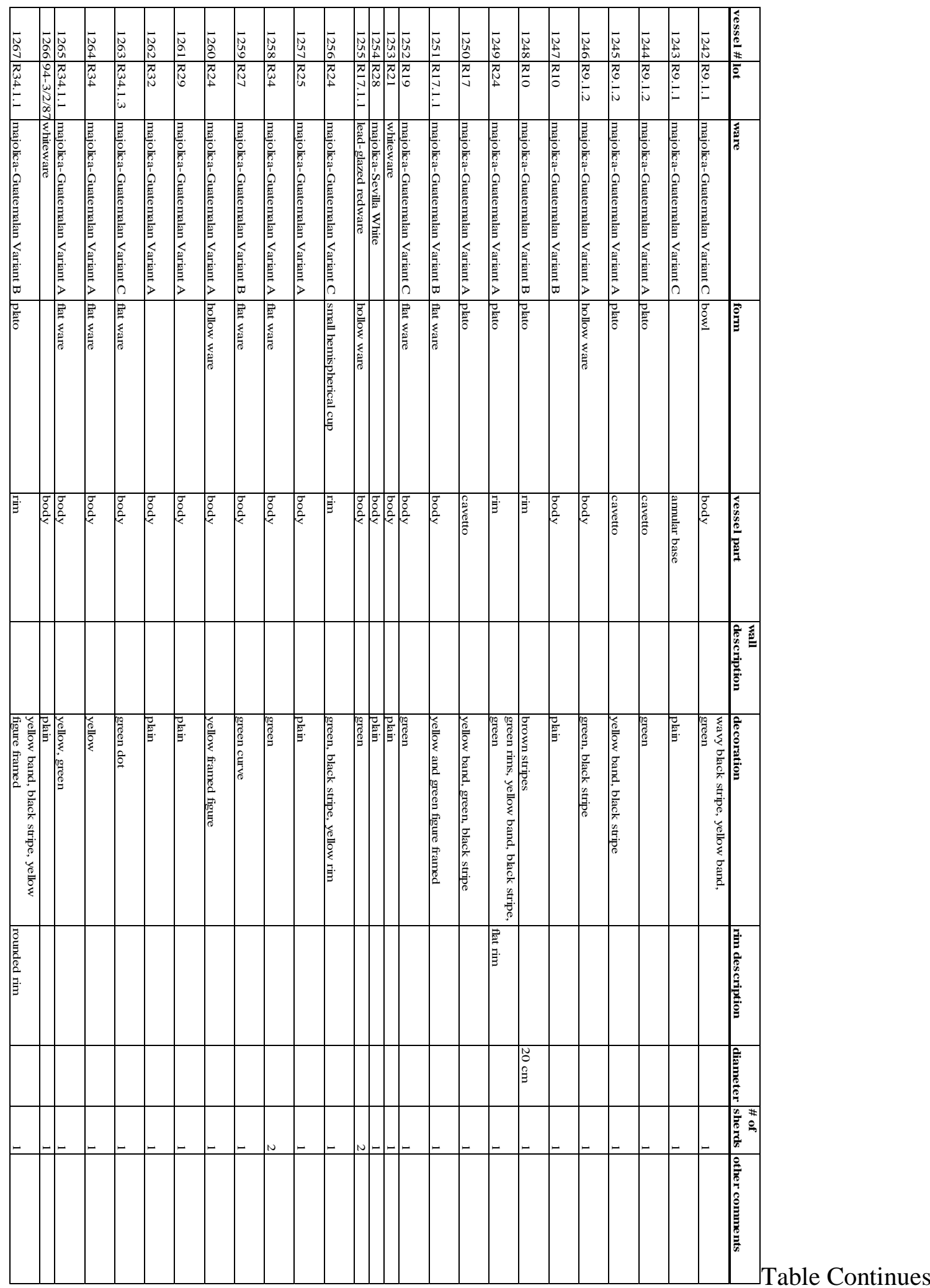



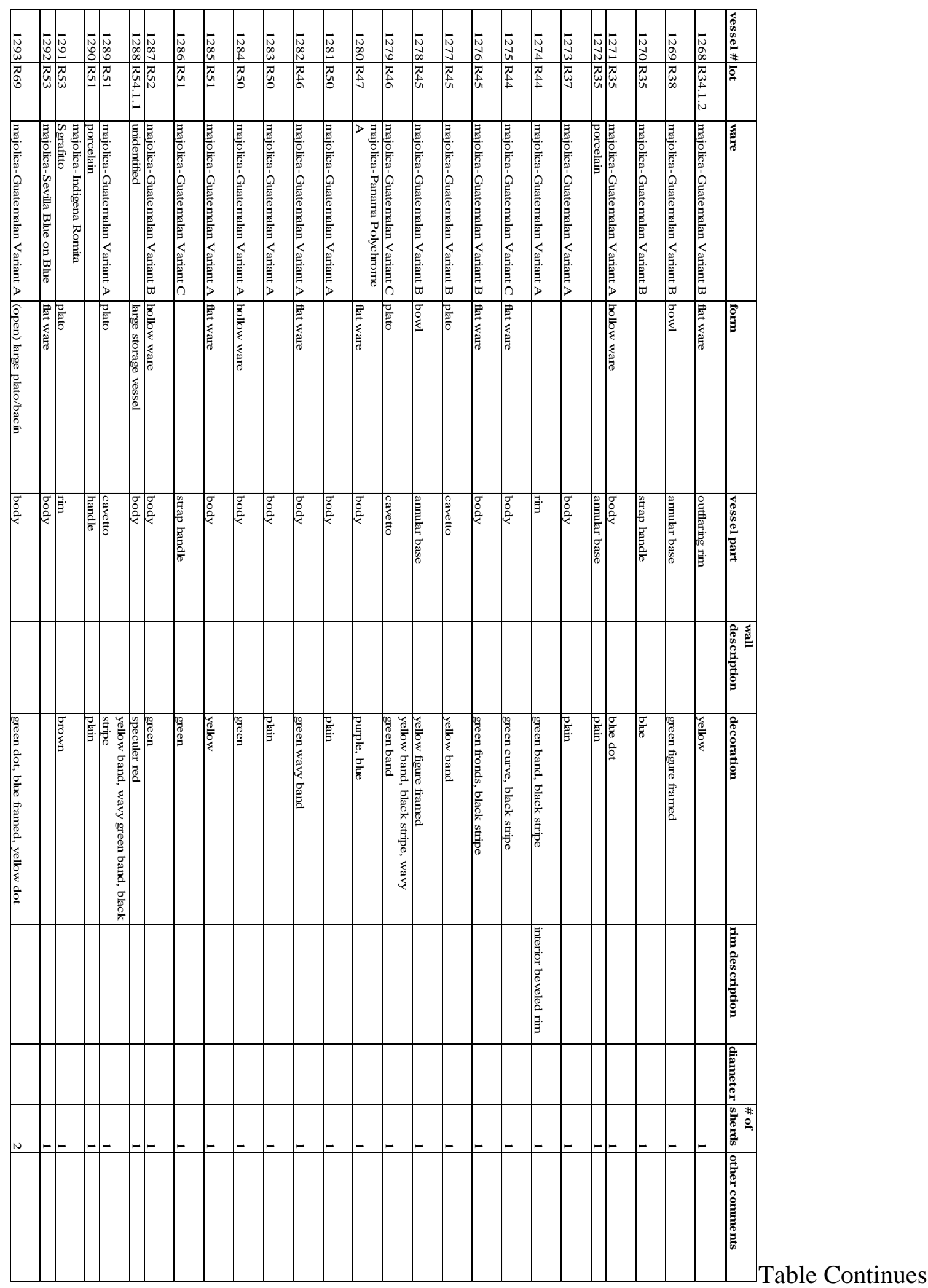


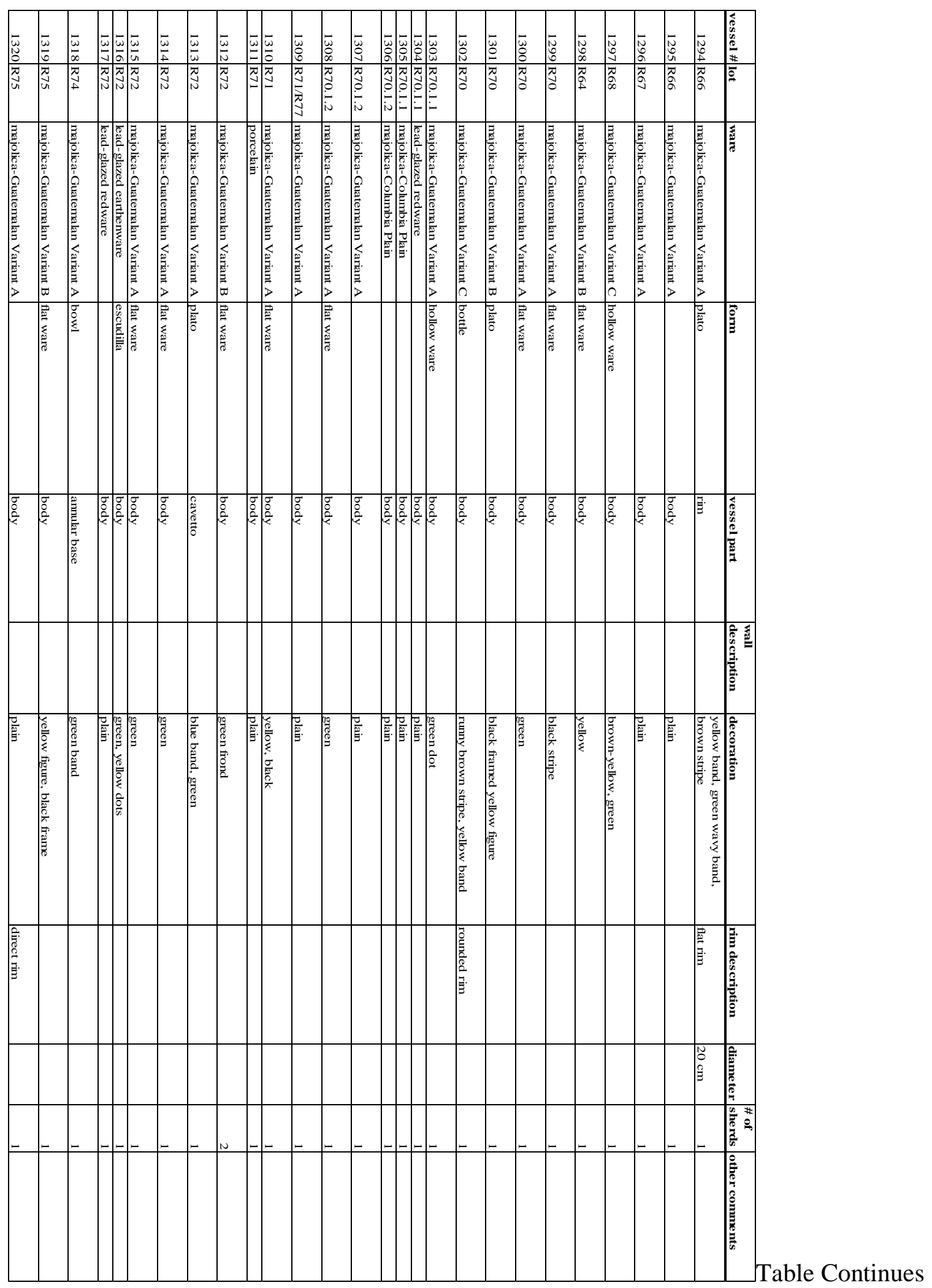



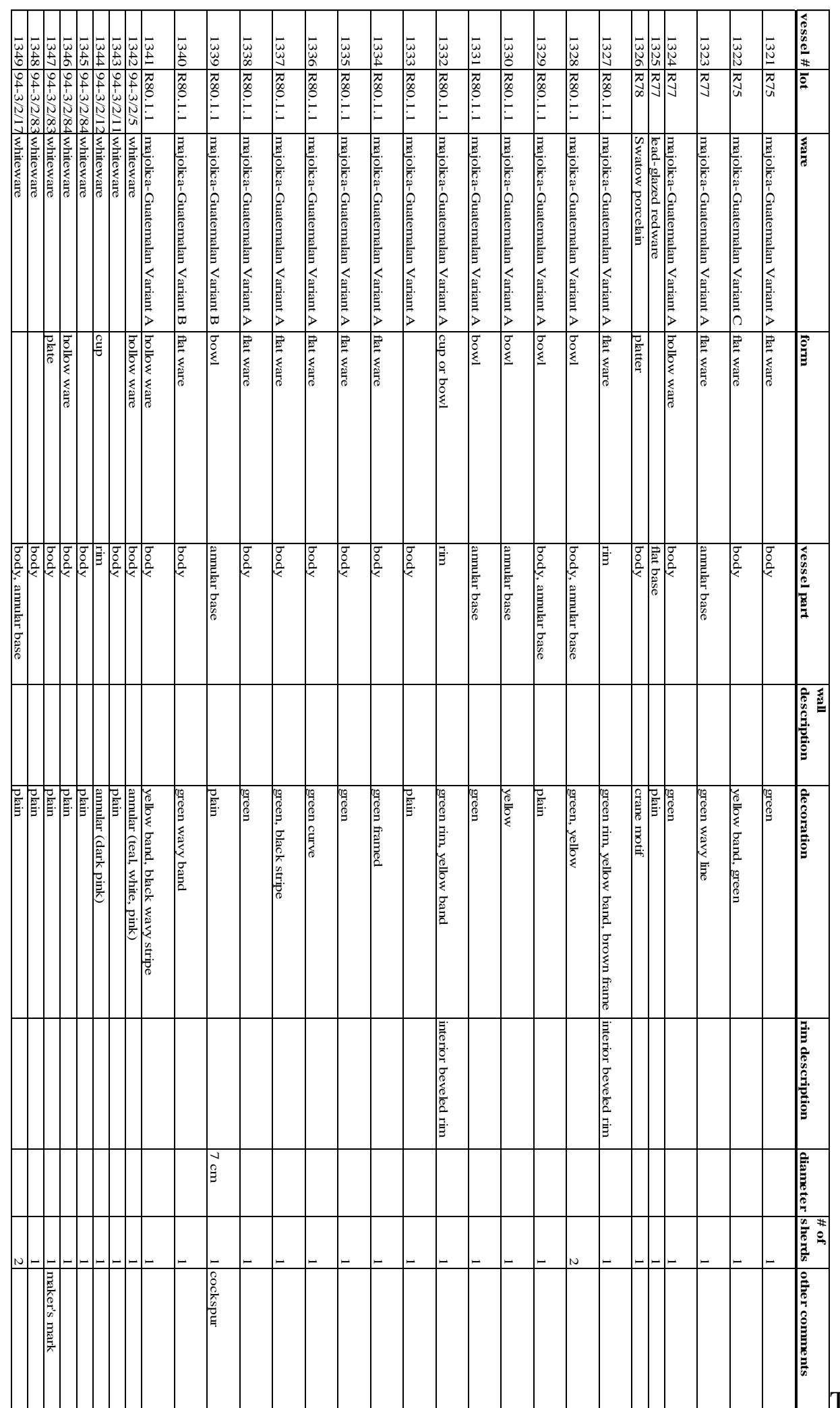

Table Continues 


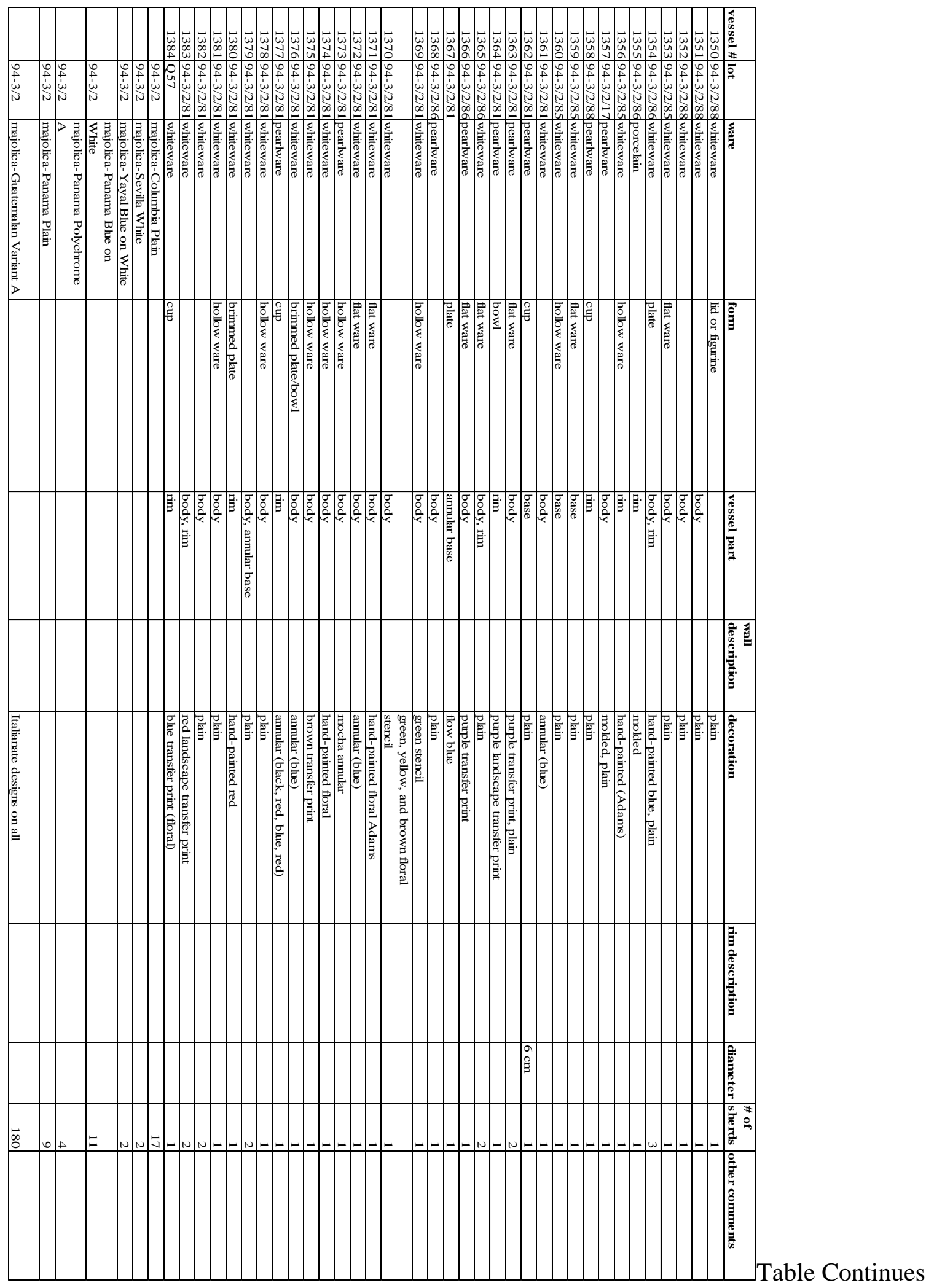




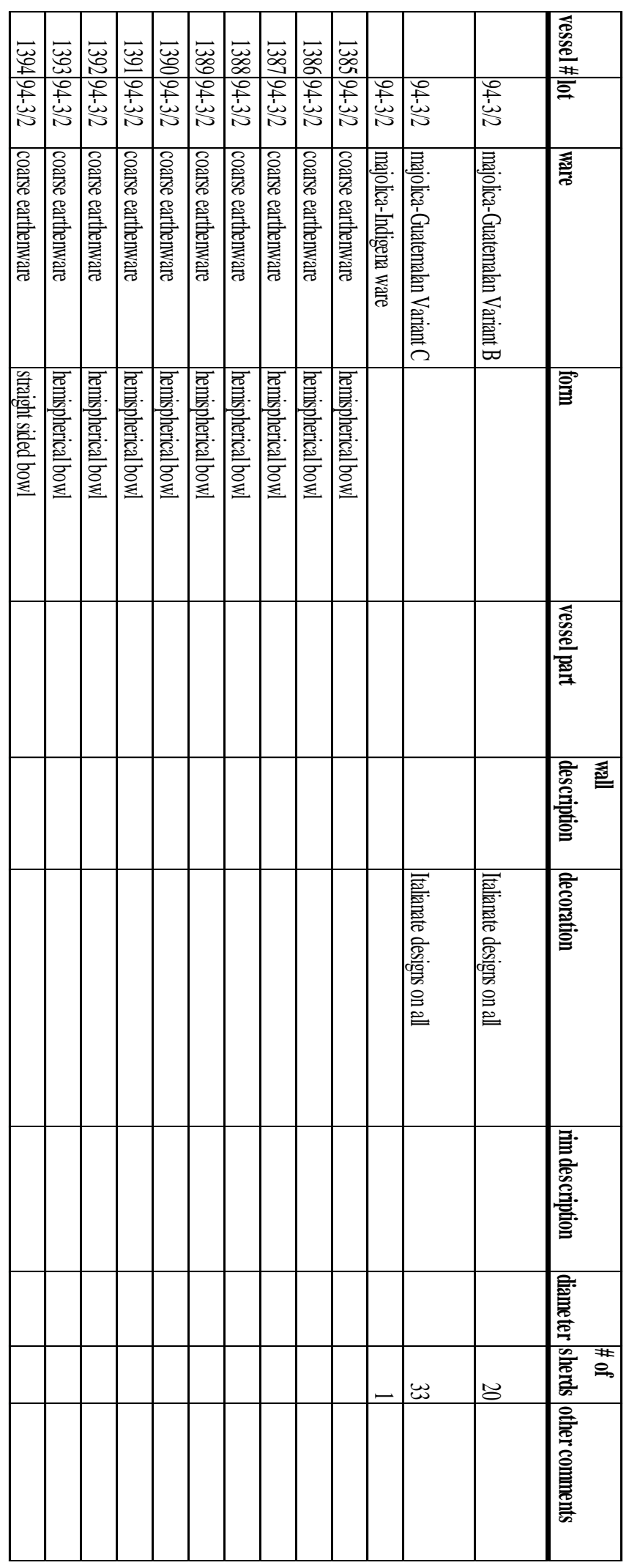


APPENDIX B

MAJOLICA TYPES COMPARED BY LOCATION 


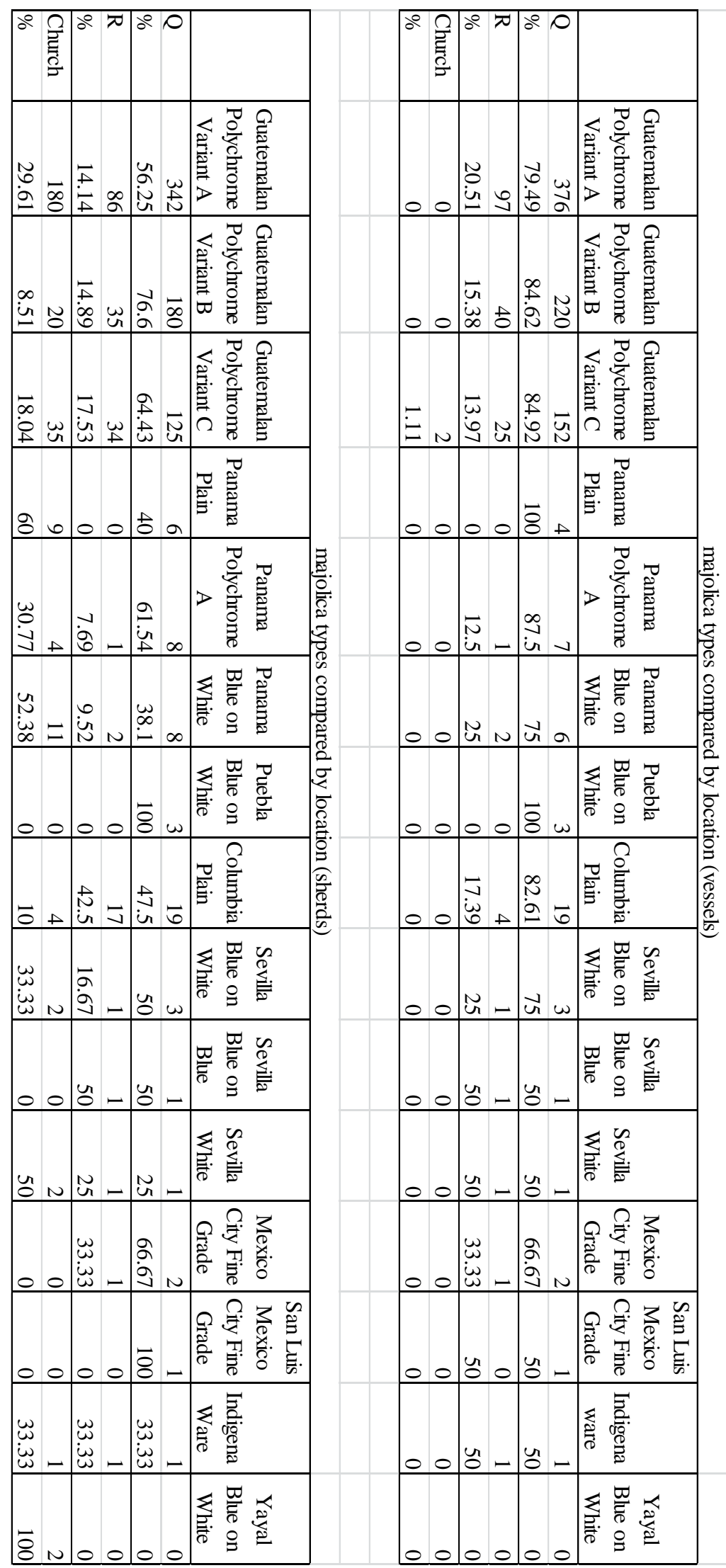


APPENDIX C

NUMBER OF VESSELS OF EACH TYPE COMPARED BY LOCATION 


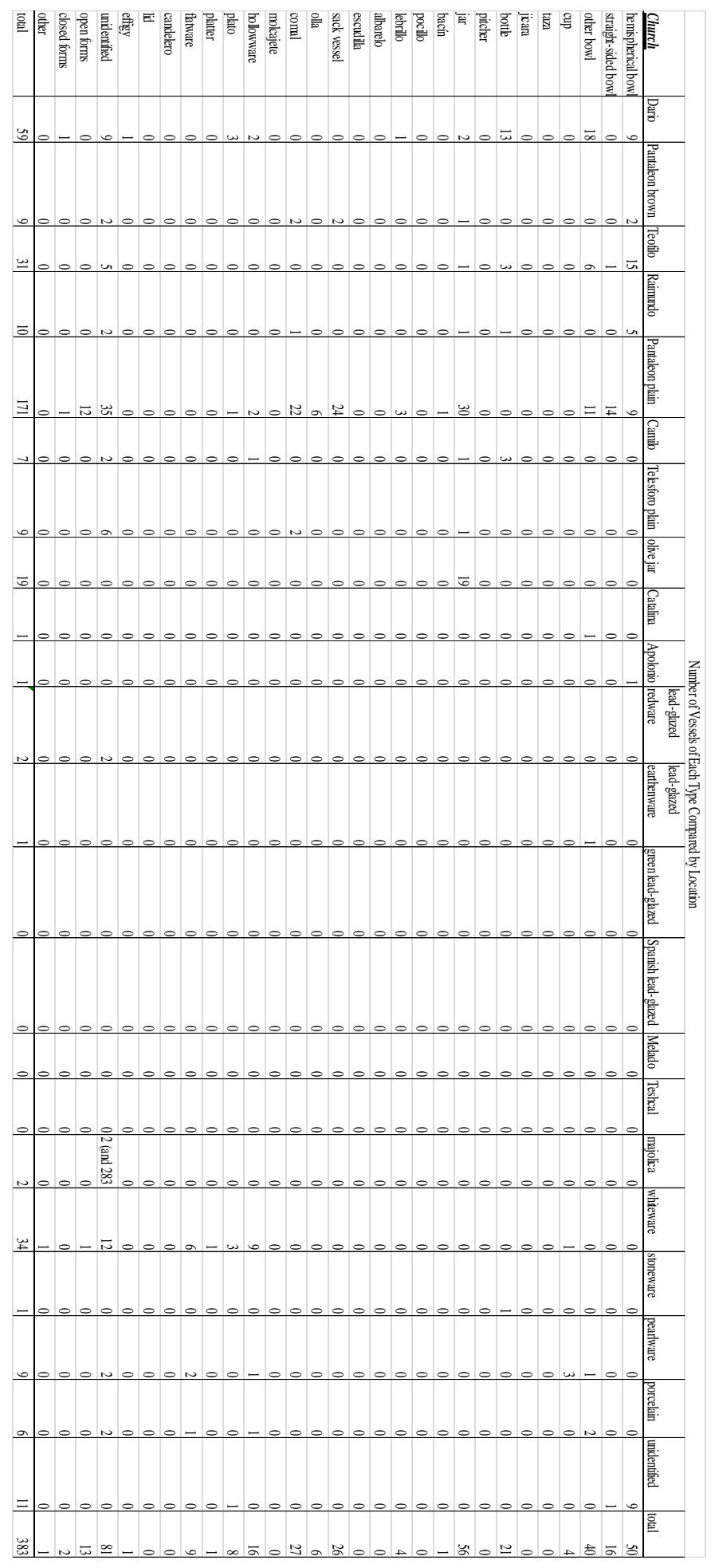

Table Continues 


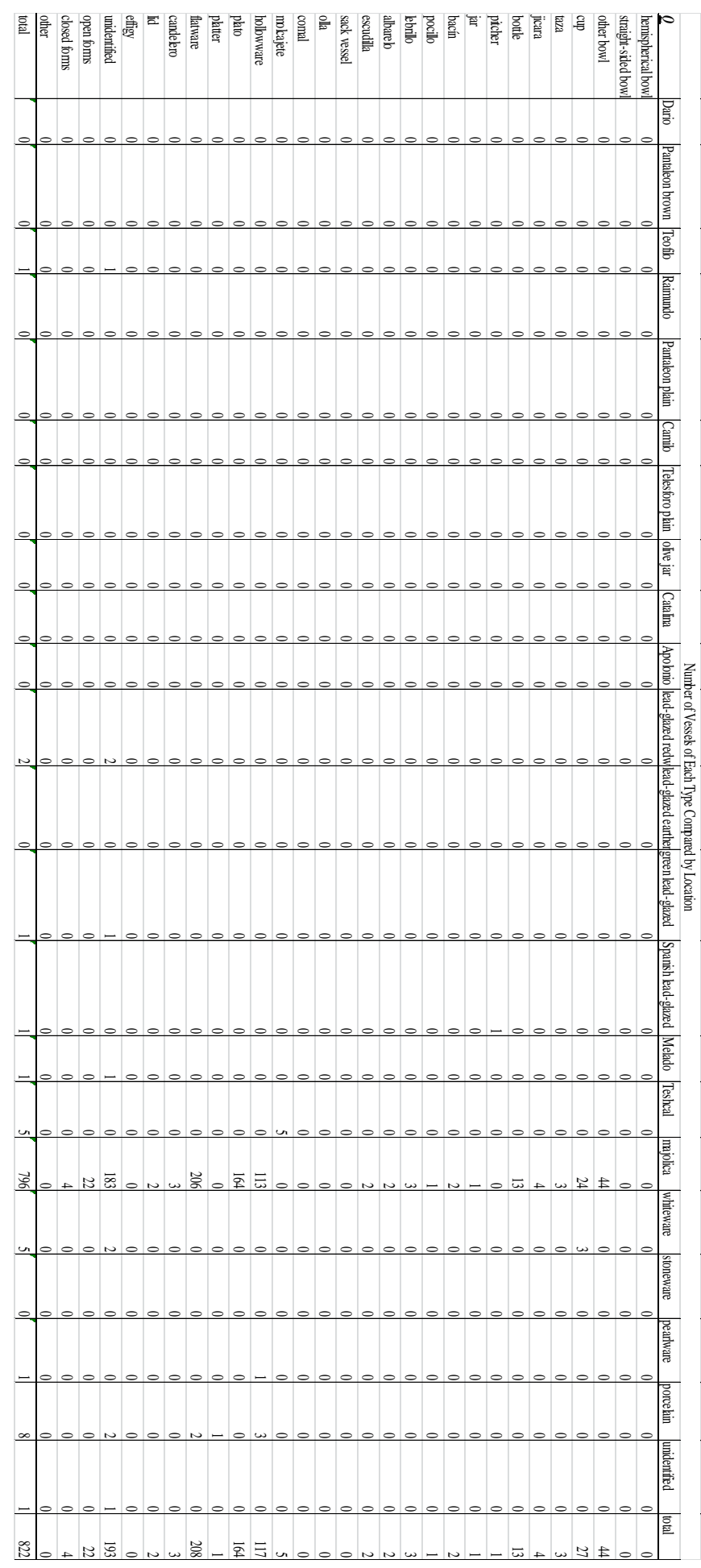

Table Continues 


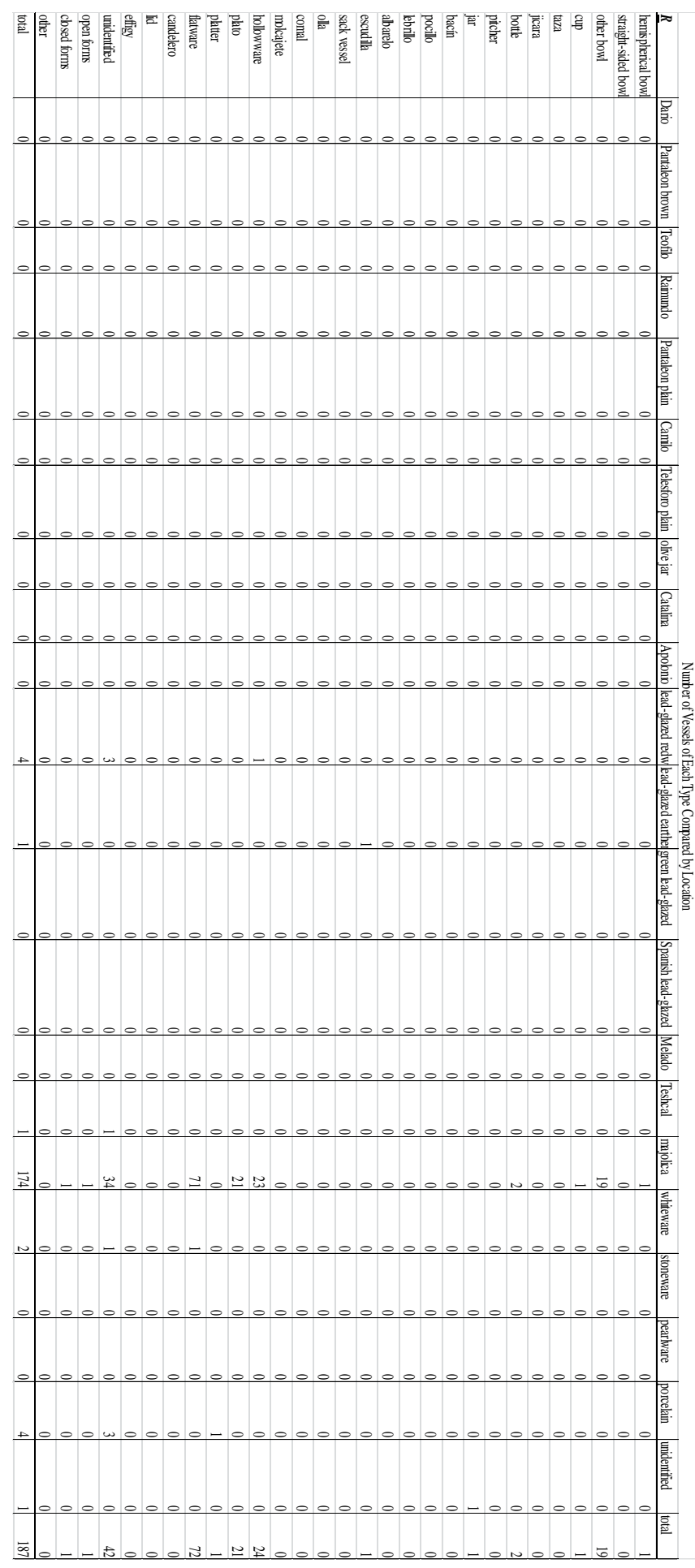


APPENDIX D

MAJOLICA DECORATIONS COMPARED BY TYPE 


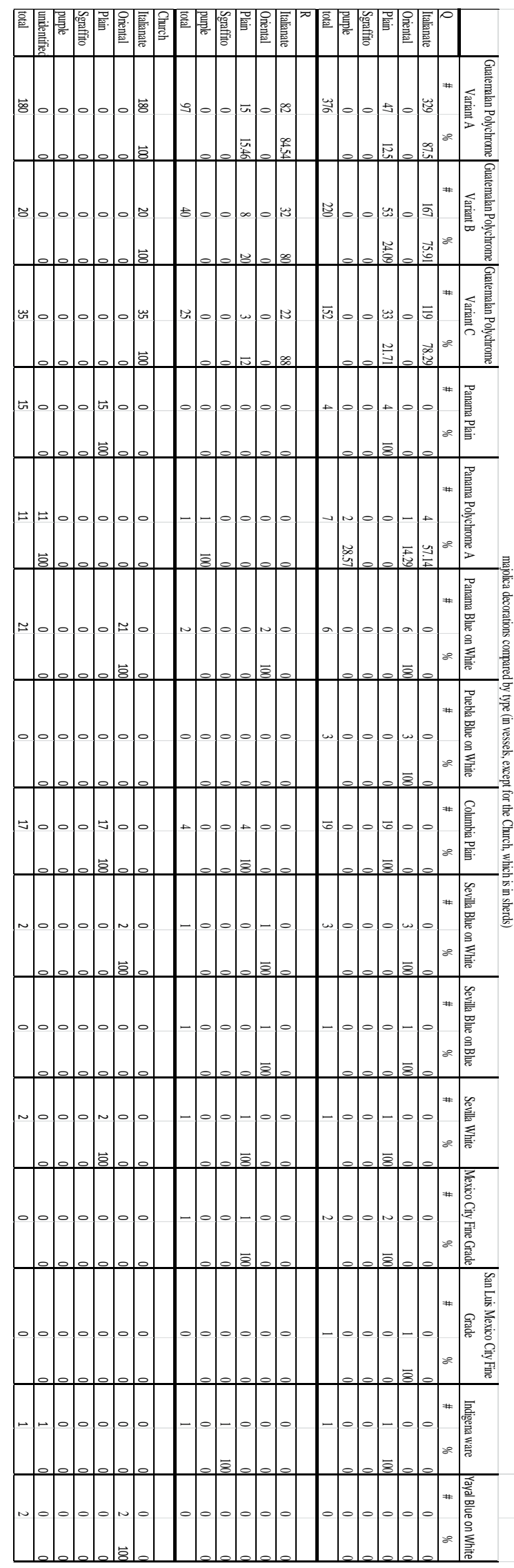


APPENDIX E

VESSEL TYPES COMPARED BY LOCATION 


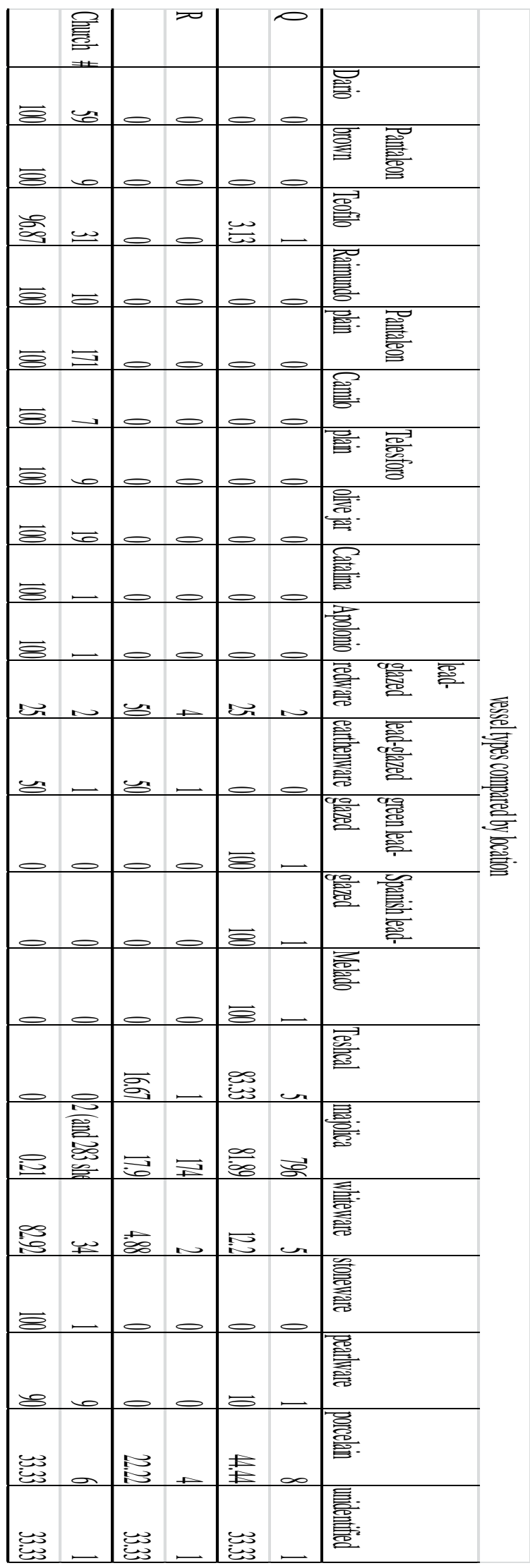


APPENDIX F

VESSEL FORMS COMPARED BY MAJOLICA TYPES AND LOCATION 

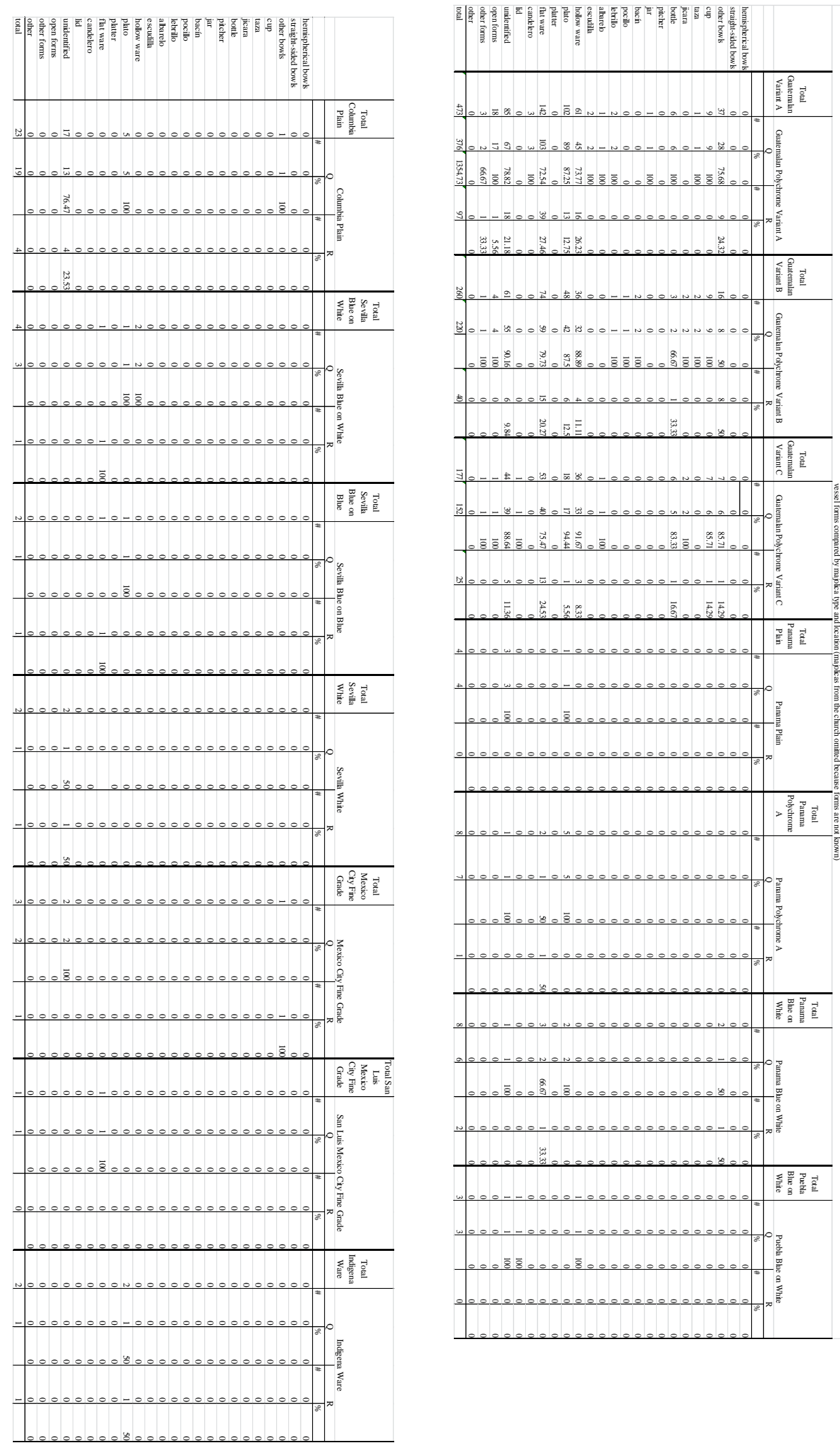
APPENDIX G

VESSEL FORMS COMPARED BY TYPE AND LOCATION 


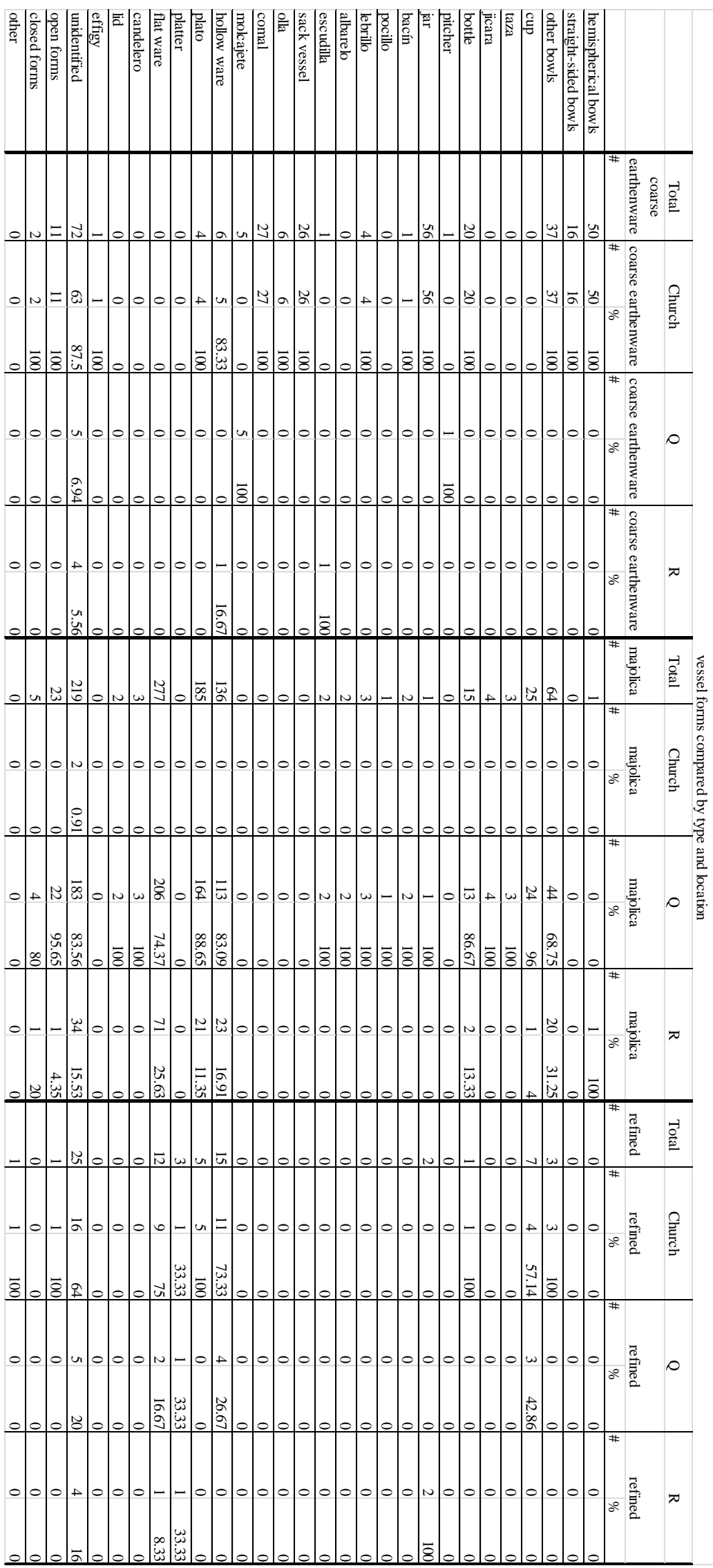


APPENDIX H

PIE CRUST RIMS 


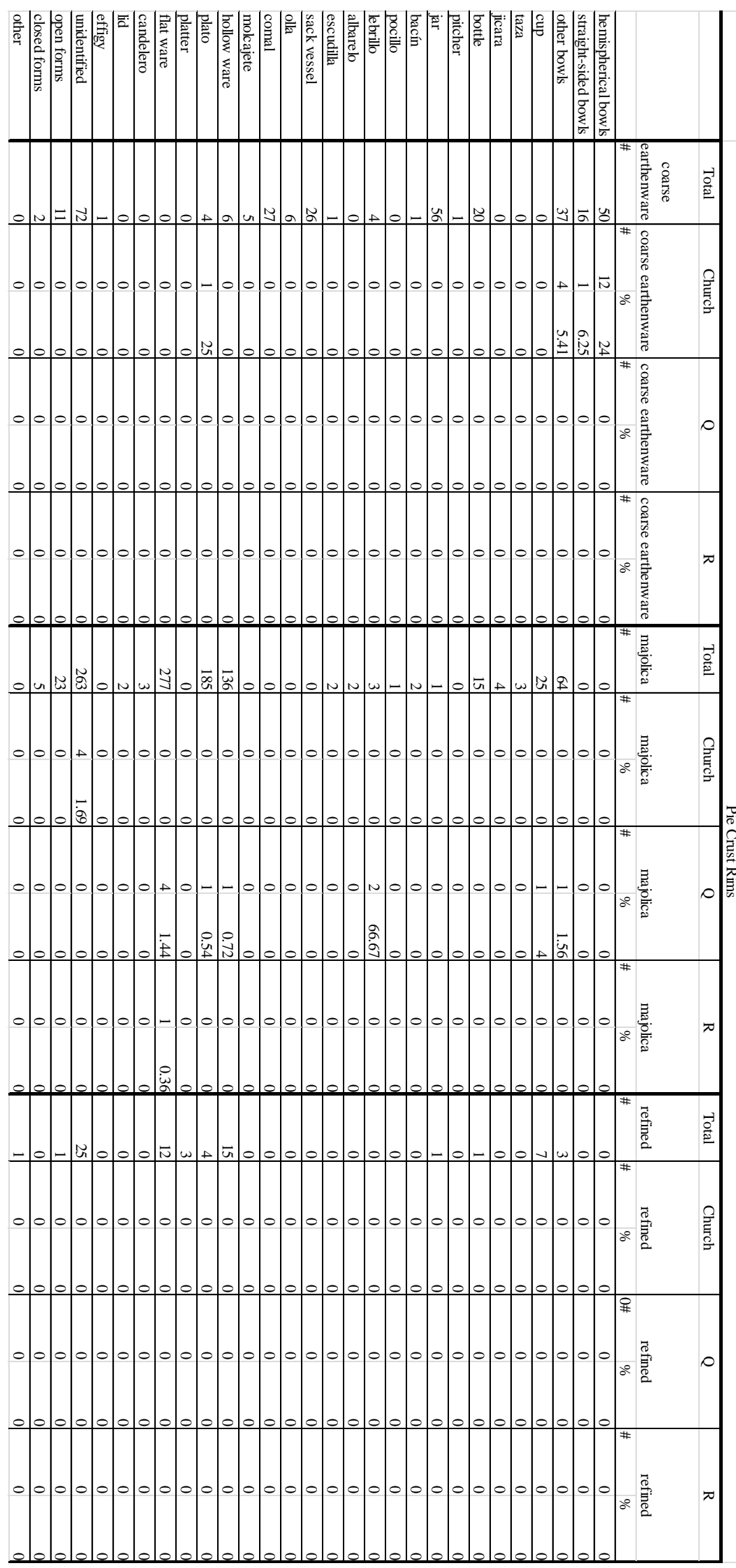

